Prepared in cooperation with the Williamsport Municipal Water Authority

\title{
Surface-Water Quality in the Lycoming Creek Watershed, North-Central Pennsylvania, August 1-3, 2011
}

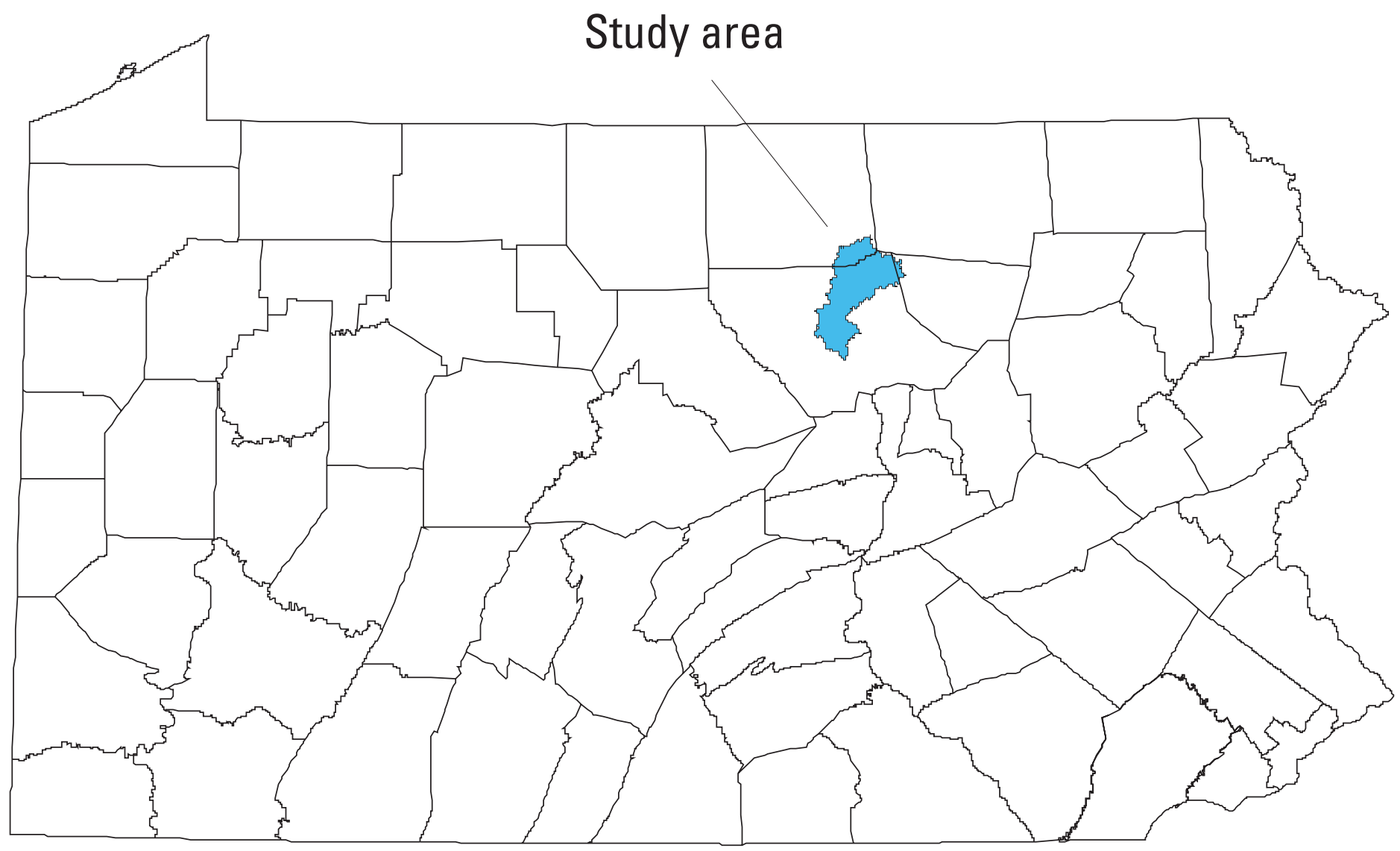

Scientific Investigations Report 2017-5154 



\section{Surface-Water Quality in the Lycoming Creek Watershed, North-Central Pennsylvania, August 1-3, 2011}

By Dennis W. Risser and Matthew D. Conlon

Prepared in cooperation with the

Williamsport Municipal Water Authority

Scientific Investigations Report 2017-5154 


\section{U.S. Department of the Interior \\ RYAN K. ZINKE, Secretary}

\section{U.S. Geological Survey James F. Reilly II, Director}

\section{U.S. Geological Survey, Reston, Virginia: 2018}

For more information on the USGS - the Federal source for science about the Earth, its natural and living resources, natural hazards, and the environment-visit https://www.usgs.gov or call 1-888-ASK-USGS.

For an overview of USGS information products, including maps, imagery, and publications, visit https://store.usgs.gov.

Any use of trade, firm, or product names is for descriptive purposes only and does not imply endorsement by the U.S. Government.

Although this information product, for the most part, is in the public domain, it also may contain copyrighted materials as noted in the text. Permission to reproduce copyrighted items must be secured from the copyright owner.

Suggested citation:

Risser, D.W., and Conlon, M.D., 2018, Surface-water quality in the Lycoming Creek watershed, north-central Pennsylvania, August 1-3, 2011: U.S. Geological Survey Scientific Investigations Report 2017-5154, 77 p.,

https://doi.org/10.3133/sir20175154.

ISSN 2328-0328 (online) 


\section{Acknowledgments}

The authors gratefully acknowledge the following individuals for their expertise, insight, and significant contributions to the study. Walter Nicholson, Director, Williamsport Municipal Water Authority, suggested the need for a study, guided the selection of watersheds for sampling, and provided local knowledge of the area. Mark Stephens, Source-Water Specialist, Pennsylvania Department of Environmental Protection (PaDEP), provided comments and suggestions on evaluation of the results. Dustin Shull from PaDEP collected surface-water samples and coordinated the analysis of samples by the PaDEP Bureau of Laboratories. Jeff Chaplin, John Clune, Edward Koerkle, and Dennis Low from the U.S. Geological Survey (USGS) also collected water samples. Colleague reviews of the report were provided by William Kappel and Drew Reif of USGS. 



\section{Contents}

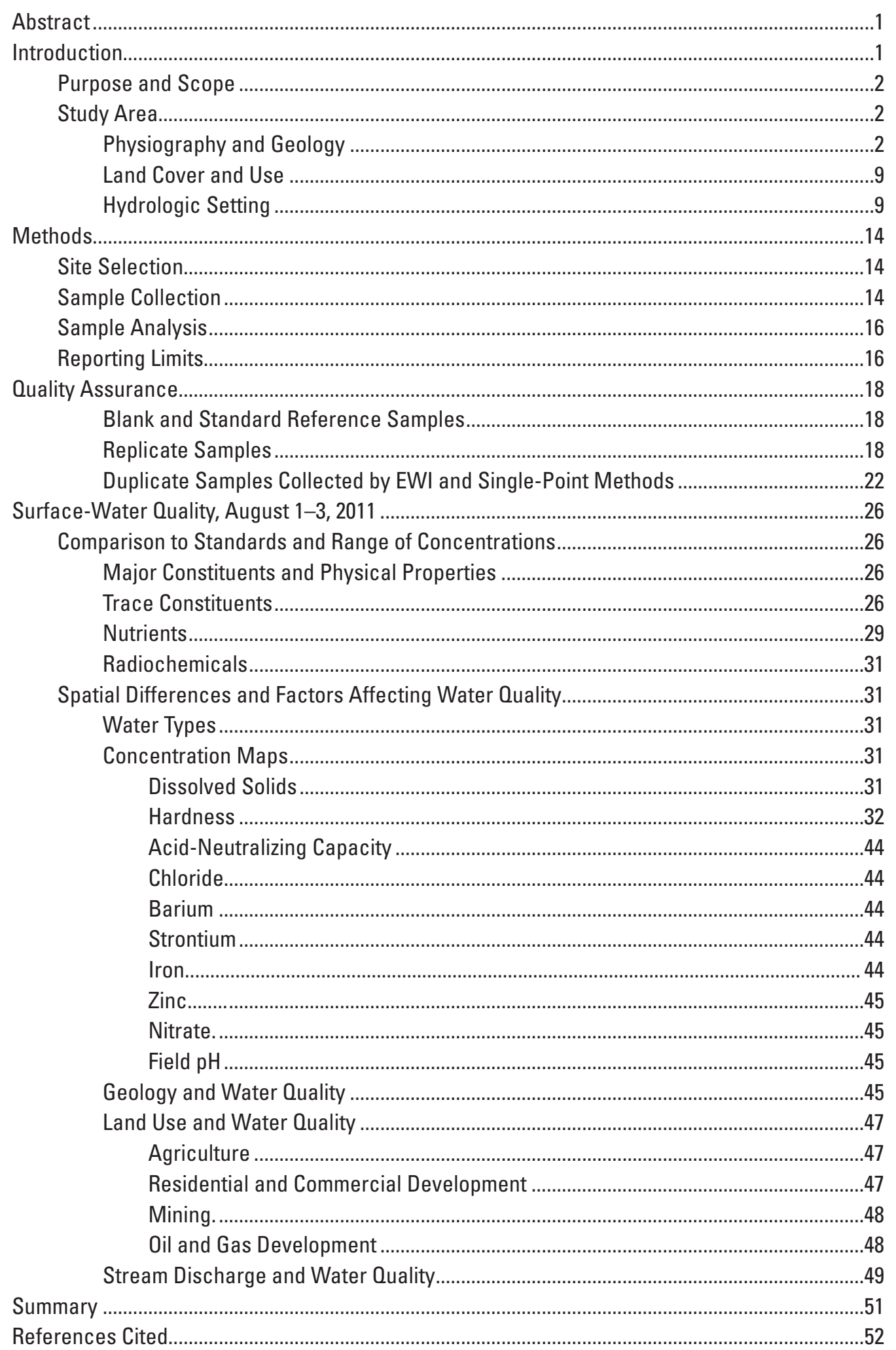




\section{Figures}

1. Map showing location of the Lycoming Creek watershed in north-central Pennsylvania and sites where surface-water samples were collected during August 1-3, 2011, by personnel from the U.S. Geological Survey and Pennsylvania Department of Environmental Protection

2. Map showing physiographic setting of the Lycoming Creek watershed in north-central Pennsylvania.

3. Map showing bedrock geology of the Lycoming Creek watershed in north-central Pennsylvania.

4. Map showing land cover as shown in the 2011 National Land Cover Database within the Lycoming Creek watershed in north-central Pennsylvania.

5. Map showing underlying bituminous coalbeds and oil and gas pools in the Lycoming Creek watershed in north-central Pennsylvania

6. Graph showing hydrograph of Lycoming Creek near Trout Run at USGS streamgage 01550000 , showing streamflow conditions when water samples were taken in relation to streamflow during 2011 and to streamflow recorded at the streamgage from 1913 to 2014

7. Graph showing streamflow in Lycoming Creek near Trout Run recorded at USGS streamgage 01550000 , and periods when stream samples were collected in the Lycoming Creek watershed, August 1-3, 2011

8. Graph showing stream discharge and specific conductance of 160 samples collected at Lycoming Creek near Trout Run for the Pennsylvania Water-Quality Network during 1975-2015.

9. Graph showing comparison of concentrations for selected water-quality constituents in surface-water samples in the Lycoming Creek watershed, north-central Pennsylvania, August 1-3, 2011

10. Graphs showing percentage of the watershed area of selected $(A)$ land uses and $(B)$ geologic formations for tributary streams and sampling sites on the main stem of Lycoming Creek, in downstream order from the upper, middle, and lower sections of Lycoming Creek watershed.

11. Image showing stiff diagrams and specific-conductance values for 20 water samples collected by the U.S. Geological Survey in the Lycoming Creek watershed, August 1-3, 2011

12. Map showing spatial variability for $(A)$ total dissolved solids, $(B)$ hardness, $(C)$ acid neutralizing capacity, $(D)$ chloride, $(E)$ barium, $(F)$ strontium, $(G)$ iron, $(H)$ zinc, (/) nitrate, and (J) field pH in the Lycoming Creek, Watershed, August 1-3, 2011

13. Graphs showing comparison of concentrations for water-quality constituents from watersheds underlain predominantly by quartz sandstone (60 percent or more Huntley Mountain Formation and younger formations) and watersheds underlain by siltstone and shale (40 percent or more Catskill Formation and older formations) within the Lycoming Creek watershed, August 1-3, 2011 for (A) nine constituents analyzed by both the U.S. Geological Survey and the Pennsylvania Department of Environmental Protection, and $(B)$ nine trace constituents analyzed by USGS

14. Graph showing relation between bromide and chloride concentrations for 14 base-flow samples from the Lycoming Creek watershed, north-central Pennsylvania, August 1-3, 2011 compared to theoretical mixing curves for freshwater with basin brine and road de-icing salts. 
15. Graph showing constituents that were elevated in water samples from Dutchman Run near Ralston and Red Run at Ralston compared to results from samples from 15 other tributary streams in Lycoming Creek watershed, north-central Pennsylvania

16. Graph showing comparison of selected water-quality constituents associated with coal mining at three sites on the main stem of Lycoming Creek, north-central Pennsylvania, August 1-3, 2011.

\section{Tables}

1. Sites where surface water was sampled by USGS and PaDEP in the Lycoming Creek watershed in north-central Pennsylvania, August 1-3, 2011.

2. Bedrock geologic units upstream of each sampling station in the Lycoming Creek watershed, north-central Pennsylvania

3. Land cover and use upstream of each sampling location in the Lycoming Creek watershed, north-central Pennsylvania

4. Comparison of water-quality constituents analyzed by the Pennsylvania Department of Environmental Protection and U.S. Geological Survey laboratories and reporting limits for samples collected from streams in the Lycoming Creek watershed, north-central Pennsylvania, August 1-3, 2011

5. Concentrations reported by the U.S. Geological Survey National Water Quality Laboratory for the inorganic blank water sample

6. Comparison of concentrations reported by the U.S. Geological Survey National Water Quality Laboratory to expected values for the standard reference samples T-181 (trace metals) and N-109 (nutrients)

7. Concentrations reported by the U.S. Geological Survey National Water Quality Laboratory for replicate samples collected from two streams in the Lycoming Creek watershed, north-central Pennsylvania, August 1-3, 2011

8. Comparison of analytical results for samples analyzed by the U.S. Geological Survey Laboratory and Pennsylvania Department of Environmental Protection Laboratory

9A. Comparison of analytical results for samples collected by the equal-widthinterval composite method and single-point sample method, analyzed by the U.S. Geologcical Survey National Water Quality Laboratory.

9B. Comparison of analytical results for samples collected by the equal-widthinterval composite method and single-point method, analyzed by the Pennsylvania Department of Environmental Protection Laboratory

10. Results of field measurements for water-quality characteristics and analyses by the U.S. Geologcial Survey laboratory for major ions, trace constituents, and nutrients for water samples collected from streams in the Lycoming Creek Watershed, north-central Pennsylvania, August 1-3, 2011

11. Detailed radiochemical analytical results for water samples collected from streams in the Lycoming Creek watershed, north-central Pennsylvania, August $1-3,2011$ 
12. Results of analyses of quality-assurance samples by the U.S. Geological Survey laboratory for major ions, trace constituents, and nutrients for water samples collected from streams in the Lycoming Creek watershed, north-central Pennsylvania, August 1-3, 2011

13. Results of analyses by the Pennsylvania Department of Environmental Protection laboratory for water-quality characteristics, major ions, trace constituents, and nutrients for water samples collected from streams in the Lycoming Creek watershed, north-central Pennsylvania, August 1-3, 2011.

14. Minimum, median, and maximum values for major constituents, trace constituents, nutrients, and radiochemicals for surface-water samples from the Lycoming Creek watershed, north-central Pennsylvania, August 1-3, 2011

15. Surface-water sampling sites where a secondary maximum contaminant level or health based screening level for at least one constituent was not achieved in the Lycoming Creek watershed, north-central Pennsylvania, August 1-3, 2011 


\section{Conversion Factors}

\begin{tabular}{lcl}
\multicolumn{1}{c}{ Inch/Pound to SI } & \multicolumn{1}{c}{ Bultiply } & \multicolumn{1}{c}{ To obtain } \\
\hline inch (in.) & Length & \\
foot (ft) & 2.54 & centimeter $(\mathrm{cm})$ \\
mile (mi) & 0.3048 & meter $(\mathrm{m})$ \\
\hline & 1.609 & kilometer $(\mathrm{km})$ \\
\hline square mile $\left(\mathrm{mi}^{2}\right)$ & Area & \\
\hline & 2.590 & square kilometer $\left(\mathrm{km}^{2}\right)$ \\
\hline gallon (gal) & Volume & \\
cubic foot $\left(\mathrm{ft}^{3}\right)$ & 3.785 & liter $(\mathrm{L})$ \\
\hline & 0.02832 & cubic meter $\left(\mathrm{m}^{3}\right)$ \\
\hline cubic foot per second $\left(\mathrm{ft}^{3} / \mathrm{s}\right)$ & Flow rate & \\
gallon per minute $(\mathrm{gal} / \mathrm{min})$ & 0.02832 & cubic meter per second $\left(\mathrm{m}^{3} / \mathrm{s}\right)$ \\
\hline & 0.06309 & liter per second $(\mathrm{L} / \mathrm{s})$ \\
\hline inch of mercury at $60^{\circ} \mathrm{F}($ in $\mathrm{Hg})$ & Pressure & \\
pound per square inch $\left(\mathrm{lb} / \mathrm{in}^{2}\right)$ & 3.377 & kilopascal $(\mathrm{kPa})$ \\
\hline & 6.895 & kilopascal $(\mathrm{kPa})$ \\
\hline picocurie per liter $(\mathrm{pCi} / \mathrm{L})$ & Radioactivity & \\
\hline
\end{tabular}

Temperature in degrees Celsius $\left({ }^{\circ} \mathrm{C}\right)$ may be converted to degrees Fahrenheit $\left({ }^{\circ} \mathrm{F}\right)$ as follows:

$$
{ }^{\circ} \mathrm{F}=\left(1.8 \times^{\circ} \mathrm{C}\right)+32 \text {. }
$$

Temperature in degrees Fahrenheit $\left({ }^{\circ} \mathrm{F}\right)$ may be converted to degrees Celsius $\left({ }^{\circ} \mathrm{C}\right)$ as follows:

${ }^{\circ} \mathrm{C}=\left({ }^{\circ} \mathrm{F}-32\right) / 1.8$.

Vertical coordinate information is referenced to the North American Vertical Datum of 1988 (NAVD 88).

Horizontal coordinate information is referenced to the North American Datum of 1983 (NAD 83).

Altitude, as used in this report, refers to distance above the vertical datum.

Specific conductance is given in microsiemens per centimeter at 25 degrees Celsius $(\mu \mathrm{S} / \mathrm{cm}$ at $\left.25^{\circ} \mathrm{C}\right)$.

Concentrations of chemical constituents in water are given either in milligrams per liter (mg/L) or micrograms per liter ( $\mu \mathrm{g} / \mathrm{L})$. 



\title{
Surface-Water Quality in the Lycoming Creek Watershed, North-Central Pennsylvania, August 1-3, 2011
}

\author{
By Dennis W. Risser and Matthew D. Conlon
}

\section{Abstract}

This report presents the methodology and results for a study of surface-water quality of the Lycoming Creek watershed in north-central Pennsylvania during August 1-3, 2011. The study was done in cooperation with the Williamsport Municipal Water Authority and the Pennsylvania Department of Environmental Protection. Samples of stream water were collected from 31 sites in an area of exploration and production of natural gas from the Marcellus Shale -5 sites on the main stem of Lycoming Creek and 26 sites on tributary streams. The samples provide a snapshot of the base-flow water-quality conditions, which helps document the spatial variability in water-quality and could be useful for assessing future changes.

The 272-square mile Lycoming Creek watershed is located within Lycoming, Tioga, and Sullivan Counties in north-central Pennsylvania. Lycoming Creek flows 37.5 miles to its confluence with the West Branch Susquehanna River in the city of Williamsport. A well field that supplies water for Williamsport captures some water that has infiltrated the streambed of Lycoming Creek. Because the stream provides a source of water to the well field, this study focused on the stream-water quality as it relates to drinking-water standards as opposed to aquatic life.

Surface-water samples collected at 20 sites by the U.S. Geological Survey and 11 sites by the Pennsylvania Department of Environmental Protection were analyzed by each agency for a suite of constituents that included major ions, trace metals, nutrients, and radiochemicals. None of the analytical results failed to meet standards set by the U.S. Environmental Protection Agency as maximum contaminant levels for drinking water.

Results of the sampling show the substantial spatial variability in base-flow water quality within the Lycoming Creek watershed caused by the interrelated effects of physiography, geology and land use. Dissolved-solids concentrations ranged from less than the laboratory reporting level of 12 milligrams per liter $(\mathrm{mg} / \mathrm{L})$ in Wolf Run, a pristine forested watershed, to $202 \mathrm{mg} / \mathrm{L}$ in Bottle Run, a watershed with more development near Williamsport. Concentrations of the major ions ranged over at least one order of magnitude; chloride had the largest range from 0.3 to $45.4 \mathrm{mg} / \mathrm{L}$, with nine samples exceeding the natural background level of about $5 \mathrm{mg} / \mathrm{L}$, most likely because of the application of deicing salt to roads. Trace constituents were even more variable, with concentrations for aluminum, cobalt, and manganese ranging over almost four orders of magnitude. Samples from Red Run and Dutchman Run, watersheds that experienced past coal mining activity, had concentrations of 11 metals that were significantly greater than in samples collected from other streams. Samples from Bottle Run, the tributary of Lycoming Creek nearest to Williamsport, contained elevated levels of chloride and boron, constituents associated with urban development.

\section{Introduction}

The Williamsport Municipal Water Authority (WMWA) is the public water supplier for about 50 percent of the population of Lycoming County. During periods of low streamflow, WMWA supplements its surface-water sources located south of the West Branch Susquehanna River with groundwater from a well field in the city of Williamsport near Lycoming Creek. The nine shallow production wells in the Lycoming Creek well field withdraw water from the alluvial sand-and-gravel aquifer. Infiltration induced from Lycoming Creek is a source of recharge to the alluvial deposits that is captured by the production wells (Spotts, Stevens, McCoy, 2009). Thus, the quality of groundwater withdrawn by the wells can be affected by the chemical composition of water in the creek. In turn, the quality of water in Lycoming Creek can be affected by landuse activities within the watershed.

Current or past land-use activities in Lycoming Creek watershed include agriculture, silviculture, aquiculture, urban development, and mining, but the most notable recent activity is related to extraction of natural gas from the Marcellus Shale. The first Marcellus Shale gas well in Lycoming Creek watershed was drilled in July 2007, and by August 1, 2011, sixty-five wells had been drilled at 38 pads in the watershed on both private and public lands (Pennsylvania Department of Environmental Protection, 2016a). During that time, briny wastewater from some gas wells in Pennsylvania was being transported to sewage-treatment facilities (outside of the Lycoming Creek watershed), where the water was treated with conventional techniques and diluted with the conventional 
wastewater before being discharged to Pennsylvania streams (Abdalla and others, 2011). That disposal practice, along with land disturbances from access roads, gas wells, and pipeline construction, caused the WMWA to have concerns about the possible effects of shale-gas development on the quality of water in Lycoming Creek. Because of that concern, WMWA asked the U.S. Geological Survey (USGS) to collect water samples in Lycoming Creek and its tributaries to provide information about water-quality conditions that could be used to assess future changes.

\section{Purpose and Scope}

This report describes the methods and results of a study, in cooperation with the WMWA and Pennsylvania Department of Environmental Protection (PaDEP), to survey the quality of water in Lycoming Creek and its tributary streams. The purpose of the study was to establish data on base-flow water quality for a broad set of chemical constituents that could provide a basis for distinguishing contaminants from various land-use activities such as natural-gas development, road maintenance, agricultural operations, and urbanization.

The quality of surface water throughout the watershed was documented with a single reconnaissance survey by collecting water samples at 31 sites on the main stem of Lycoming Creek and its tributary streams during base-flow conditions August 1-3, 2011 (fig. 1 and table 1). The samples were analyzed for field constituents, major ions, nutrients, trace metals, and radiochemicals. The results provide a snapshot of water quality during that single base-flow condition. The concentrations of the water-quality constituents found in water samples from streams are presented and compared against U.S. Environmental Protection Agency (EPA) drinking-water standards or health-based screening levels. Differences in water chemistry throughout the watershed are discussed in relation to geology and land use. Quality-assurance samples are discussed to evaluate possible errors introduced by contamination in the field, sampling methods, and different laboratories used to analyze the samples. Data are presented in tables; data also are available online through the USGS National Water Information System (NWIS) (U.S. Geological Survey, 2017), and can be accessed by using the station identifiers in table 1 .

\section{Study Area}

Lycoming Creek watershed covers 272 square miles $\left(\mathrm{mi}^{2}\right)$ in Lycoming, Tioga, and Sullivan Counties in north-central Pennsylvania (fig. 1). From its headwaters in northern Lycoming County, Lycoming Creek flows 37.5 miles to its confluence with West Branch Susquehanna River in Williamsport. The Lycoming Creek well field is near the confluence. The diversity in physiography, geology, land use, and hydrologic setting within the watershed all influence the quality of water flowing past the well field.

\section{Physiography and Geology}

The Lycoming Creek watershed is situated within the Ridge and Valley and Appalachian Plateaus Physiographic Provinces (fig. 2). The southern part of the watershed (about 16 percent) lies within the Susquehanna Lowland Section of the Ridge and Valley Province (Sevon, 2000), which is characterized in this area by low to moderate relief developed mostly on shale, siltstone, and sandstone of Devonian age. The majority of the watershed (about 84 percent) is situated within three different sections of the Appalachian Plateaus Physiographic Province - the Deep Valleys Section, Glaciated Low Plateau Section, and Glaciated High Plateau Section. The Deep Valleys and Glaciated High Plateau sections compose the middle part of the watershed, which is characterized by steep relief, deep valleys, and broad to narrow ridges capped by sandstones of Mississippian and Pennsylvanian age. The Glaciated Low Plateau Section and a small sliver of the Glaciated High Plateau Section compose the northern part of the watershed. The Glaciated Low Plateau section is characterized by rounded hills and broad valleys of low relief carved into shale, siltstone, and sandstone of Devonian age.

Land-surface altitudes range widely across the watershed. The highest altitude is about 2,380 feet on the watershed boundary in Sullivan County within the Glaciated High Plateau Section of the Appalachian Plateaus Province; the lowest is about 510 feet at the confluence of Lycoming Creek and the West Branch Susquehanna River within the Susquehanna Lowland Section of the Valley and Ridge Province.

Lycoming Creek watershed is underlain by clastic bedrock units of Devonian, Mississippian, and Pennsylvanian age consisting predominantly of siltstone, shale, and sandstone, with some coal. The bedrock geologic units, as shown on the geologic map of Pennsylvania (Miles and Whitfield, 2001) from oldest to youngest are the Old Port Formation, Onondaga Formation, Hamilton Group, Brallier Formation, Harrell Formation, Lock Haven Formation, and Catskill Formation of Devonian age; the Huntley Mountain Formation of Devonian and Mississippian ages; the Burgoon Sandstone and Mauch Chunk Formation of Mississippian age; and the Pottsville and Allegheny Formations of Pennsylvanian age (fig. 3 and table 2). The Onondaga and Old Port Formations are not included on figure 3 and table 2 because their outcrop areas, at the confluence of Lycoming Creek and West Branch Susquehanna River, are too small to be shown. The bedrock units are considered aquifers because all are capable of producing adequate quantities of water for domestic use, though adequate yields for public supply are less reliable.

Glaciers covered the entire watershed during the preIllinoian Stage and about two-thirds of the watershed during the latest glacial advance, the Wisconsinan Stage. The south boundary of the Wisconsinan glaciation is shown in figure 3 (Sevon and Braun, 2000). Glaciers deposited a thin mantel of glacial till on the uplands, and stratified sand and gravel deposits predominantly along the main stem of Lycoming 


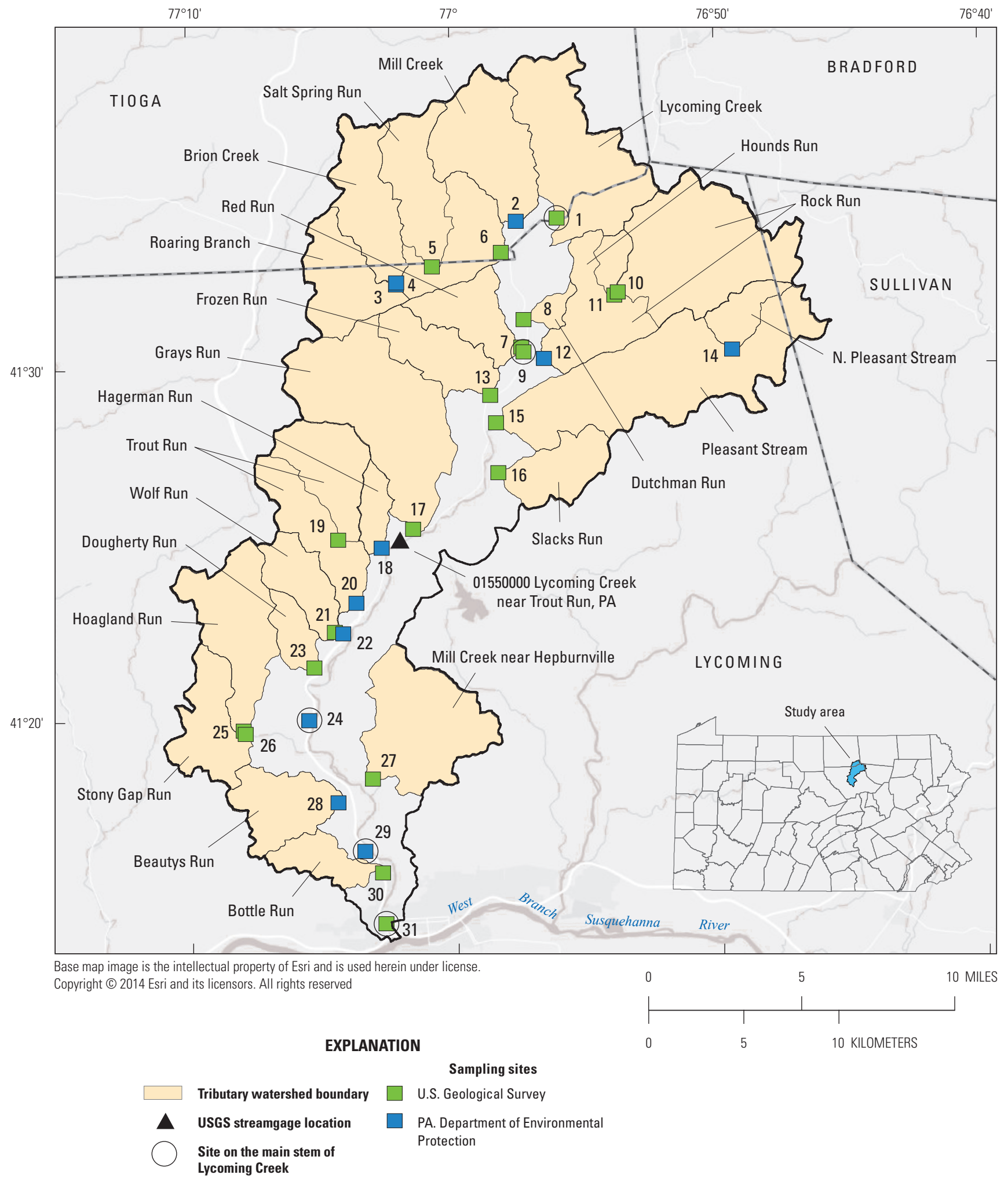

Figure 1. Location of the Lycoming Creek watershed in north-central Pennsylvania and sites where surface-water samples were collected during August 1-3, 2011, by personnel from the U.S. Geological Survey and Pennsylvania Department of Environmental Protection. See table 1 for key to station numbers. 
Table 1. Sites where surface water was sampled by USGS and PaDEP in the Lycoming Creek watershed in north-central Pennsylvania, August 1-3, 2011.

[ID, identifier; PA, Pennsylvania; USGS, U.S. Geological Survey; PaDEP, Pennsylvania Department of Environmental Protection; NAD, North American Datum of 1983; mi², square miles; St., street; dark shading indicates site on main stem of Lycoming Creek; --, no data]

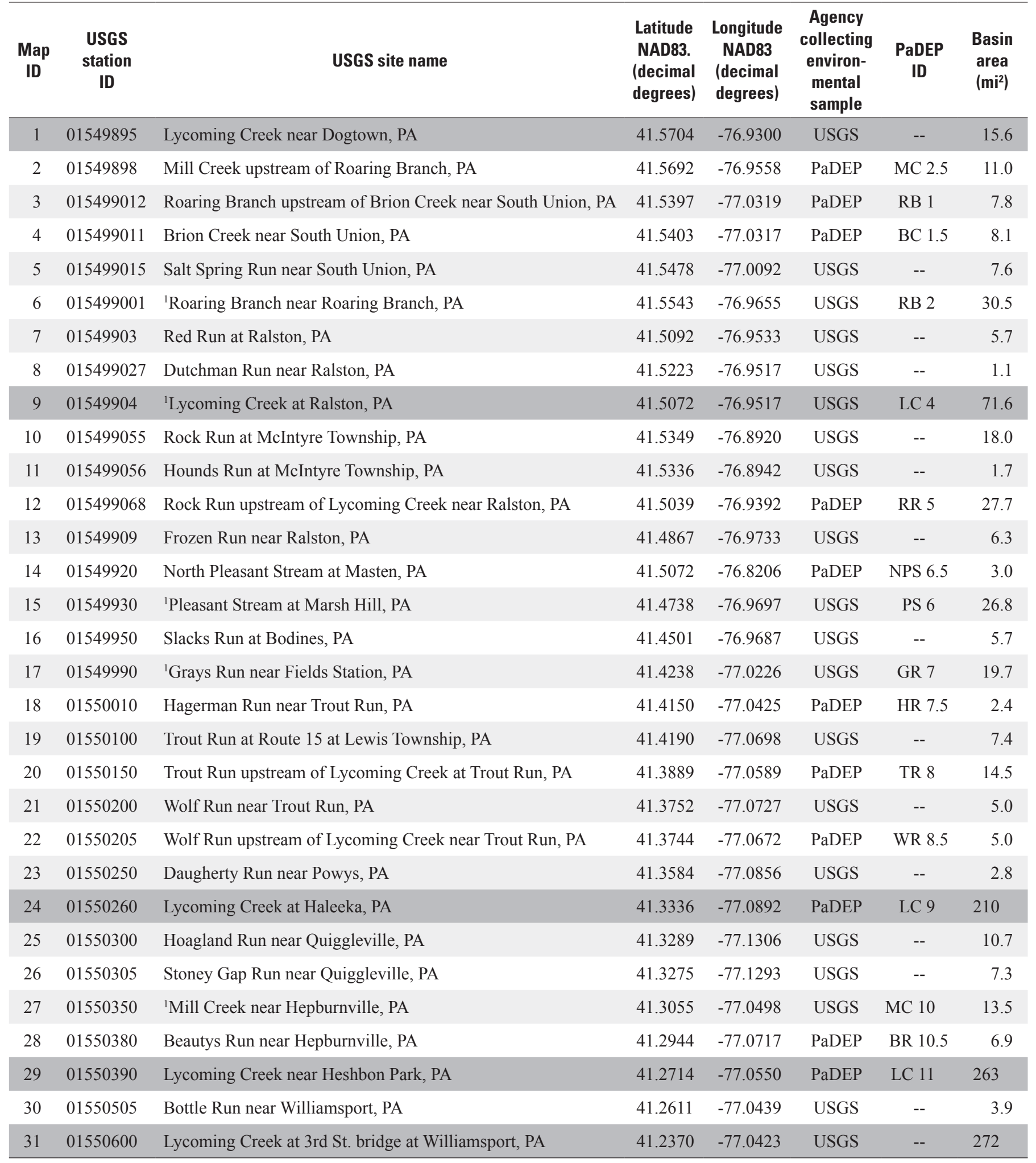

${ }^{1}$ Site where quality-assurance samples were collected by USGS and PaDEP personnel to evaluate the effects of different sample-collection protocols and laboratories. 

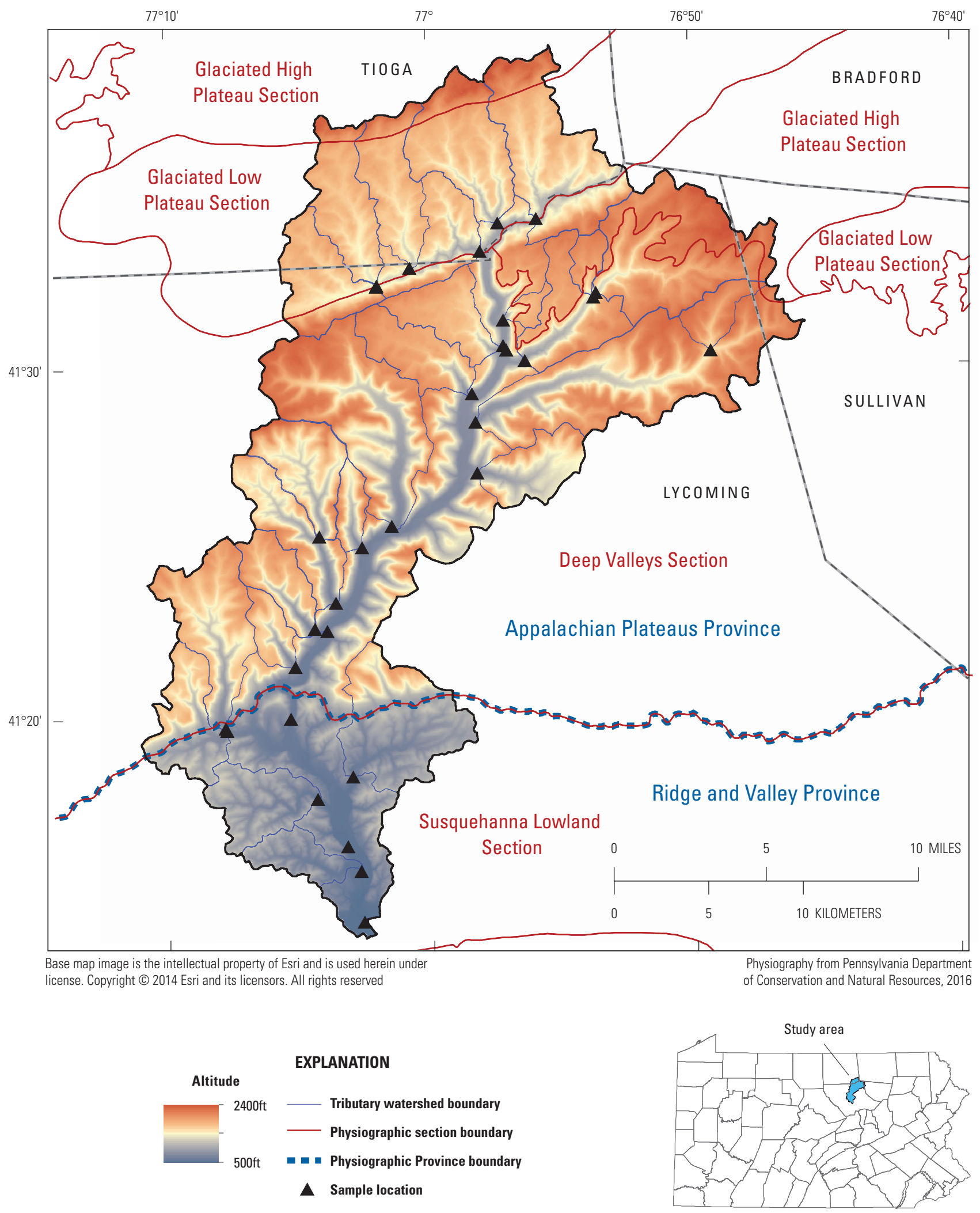

Figure 2. Physiographic setting of the Lycoming Creek watershed in north-central Pennsylvania. 


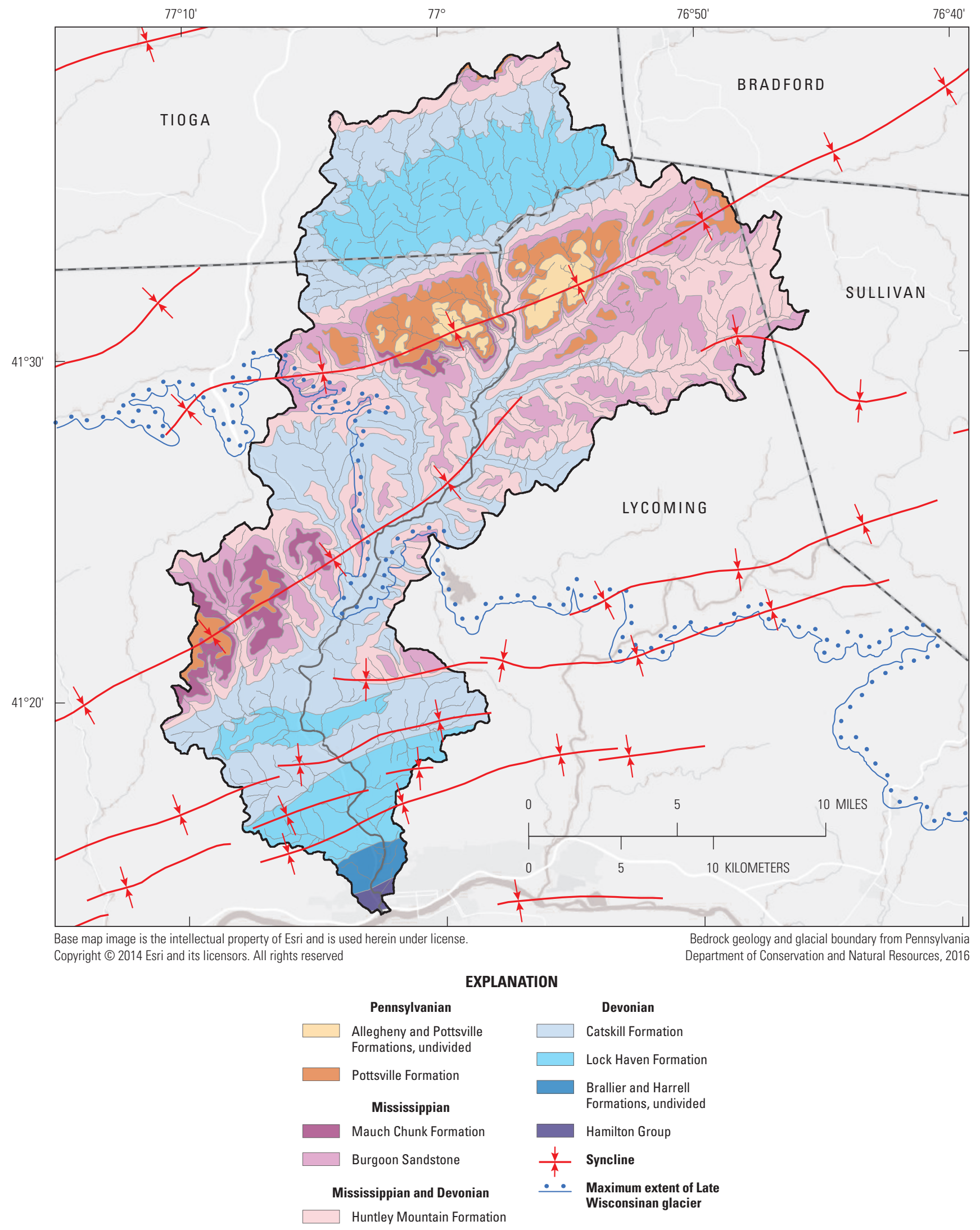

Figure 3. Bedrock geology of the Lycoming Creek watershed in north-central Pennsylvania. 


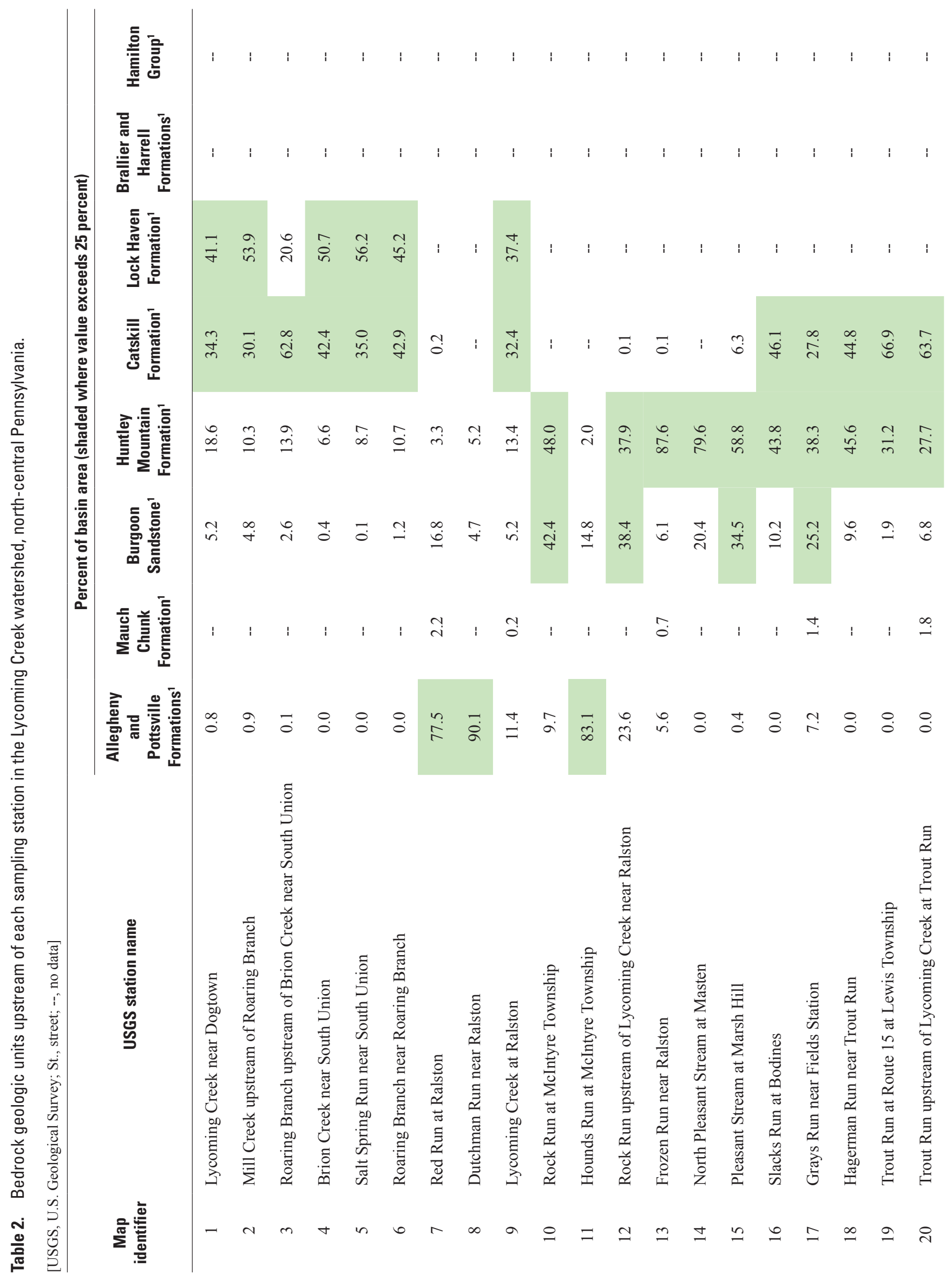




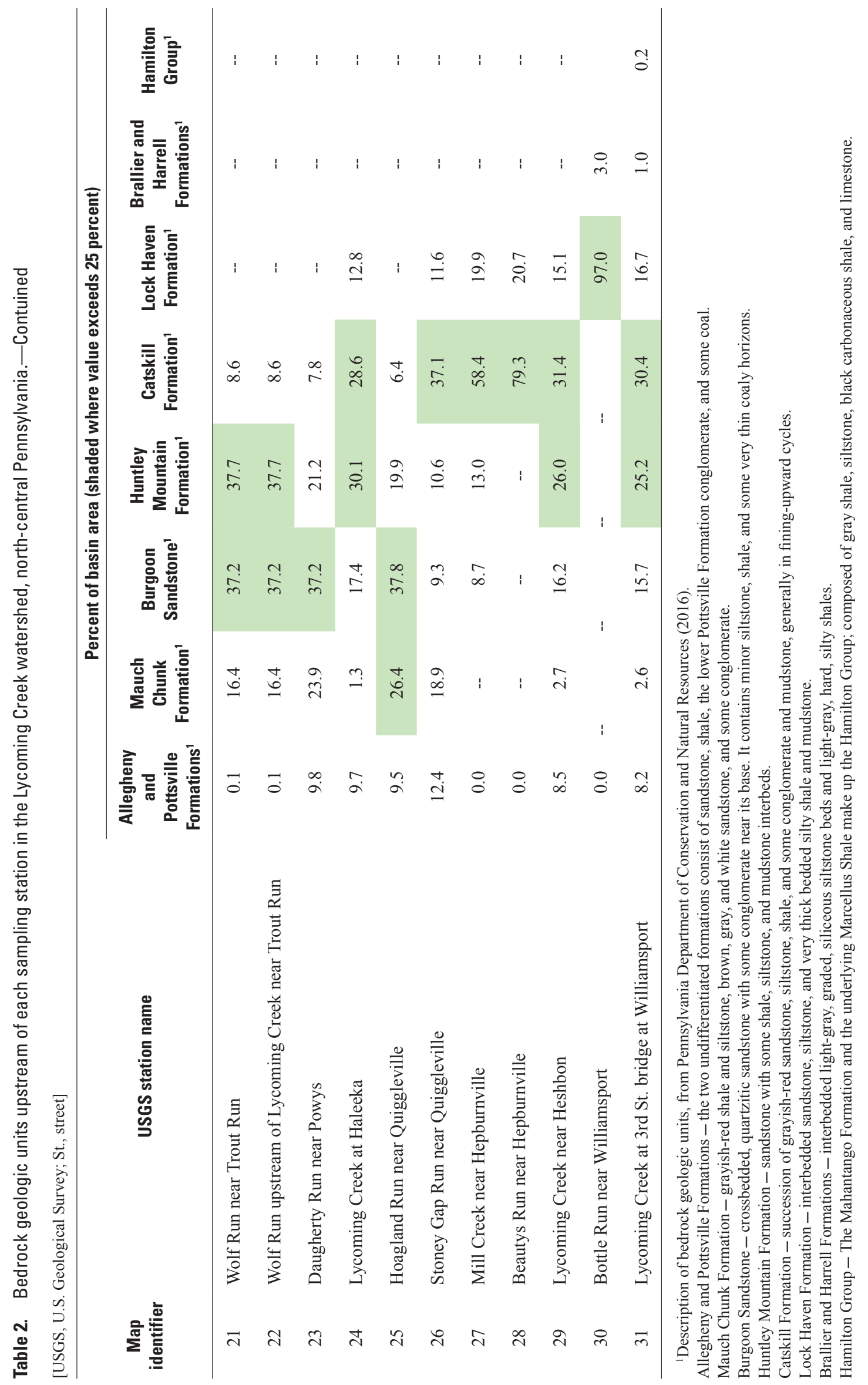


Creek. The stratified sand-and-gravel deposits along Lycoming Creek form by far the most productive aquifer in the watershed, capable of yielding as much as 3,000 gallons per minute (gal/min) of water to wells (Lloyd and Carswell, 1981). The Lycoming Creek well field is located within the glacial deposits along Lycoming Creek.

\section{Land Cover and Use}

Lycoming Creek watershed is primarily a mix of forested and agricultural lands with some small areas of past coal mining and more recent suburban and commercial development. About 79 percent of the land is characterized as forested and 15 percent agricultural in the 2011 National Land Cover Database (NLCD) (Homer and others, 2015). The land cover classes are illustrated in figure 4 and table 3 . The land cover is related to the physiography and geology of the watershed and land ownership. Agricultural lands are concentrated in the northern and southern parts of the watershed and along Lycoming Creek. These areas are underlain predominantly by siltstone and shale beds of Devonian age, and are privately owned. Most of the forested lands are in the rugged topography in the middle part of the watershed within the Deep Valleys and Glaciated High Plateau sections of the Appalachian Plateaus Physiographic Province, which is underlain by the coarser clastic bedrock of Mississippian and Pennsylvanian age. Large tracts of the forest are on public lands managed as Pennsylvania State Forest or Game Lands.

The Lycoming Creek watershed is not densely populated. The creek joins the West Branch Susquehanna River within the city of Williamsport, but only about 4 percent of the watershed is categorized as developed in the NLCD dataset. The population of Williamsport in 2010 was 29,381 (U.S. Census Bureau, 2010). The developed area is concentrated in the southern part of the watershed within and near the city of Williamsport, and in the valley along the main stem of Lycoming Creek. U.S. Route 15 is a major north-south transportation artery. From Williamsport, it follows Lycoming Creek north for about 12.5 miles, turns northwest up the Trout Run valley, and leaves the basin at the headwaters of the Trout Run watershed.

Treated wastewater from the city of Williamsport is discharged to the West Branch Susquehanna River downstream from the confluence with Lycoming Creek. Four discharges of septic or treated sewage waste to Lycoming Creek are reported from manufacturing facilities (Pennsylvania Department of Environmental Protection, 2017). They are downstream from the mouth of Grays Run (site 17 on fig. 1).

Coal has been mined in the Lycoming Creek watershed by surface and underground methods. The coal occurs in the Allegheny Formation, and to a lesser degree, in the Pottsville Formation, which is part of Pennsylvania's north-central bituminous coal field (fig. 5). Some of the areas categorized on figure 4 as barren land are old mining sites. Five of the tributary watersheds (Red Run, Dutchman Run, Rock Run, Frozen
Run, and Hoagland Run) contain areas that were formerly mined (table 3).

Although small deposits of oil and gas have been found in the past (Pennsylvania Department of Conservation and Natural Resources, 2016), few wells were drilled in the Lycoming Creek watershed until the beginning of exploration for natural gas from the Marcellus Shale. Six conventional vertical gas wells, all drilled prior to 2007 and subsequently plugged, are in the watershed (Pennsylvania Department of Environmental Protection, 2016a). Between July 23, 2007, and August 1, 2011, thirty-eight well pads were constructed and 65 wells were drilled to produce natural gas from the Marcellus Shale (Pennsylvania Department of Environmental Protection, 2016a). In 2011, drilling was concentrated in the northern and western parts of the watershed (fig. 5); by the end of 2015, 213 additional wells had been drilled.

\section{Hydrologic Setting}

There are about 530 miles of mapped streams within the Lycoming Creek watershed (U.S. Geological Survey, 2016a). The three largest tributaries to Lycoming Creek (in terms of watershed area) are Roaring Branch, Pleasant Stream, and Rock Run (fig. 1). Streamflow in Lycoming Creek and its tributaries originates from precipitation within the watershed. Normal average-annual precipitation for the watershed was 39.4 inches during 1971-2000, but it varies between 33 and 43 inches depending on location (Prism Climate Group, 2003). Runoff measured in Lycoming Creek near Trout Run at USGS streamgage 01550000 during the same period, expressed as a depth over the watershed, was 24.9 inches (63 percent of precipitation).

Precipitation that is not lost to evapotranspiration either runs off directly to streams or infiltrates the soil and glacial overburden and moves downward to the water table through fractures in bedrock or through open pores in the sandand-gravel aquifer. Groundwater moves from areas of high hydraulic head beneath hills toward areas of lower hydraulic head in valleys, where it discharges to streams and springs. Some groundwater probably moves beneath small headwater streams to discharge in larger streams at lower altitudes. The groundwater-flow system probably consists of shallow flow paths of recently recharged water that discharge to headwater streams, nested within deeper flow paths of older groundwater that discharge to the main stem of Lycoming Creek and its major tributaries.

The depth of groundwater circulation is not accurately known, but according to Lloyd and Carswell (1981), most groundwater discharging as base flow to streams probably has circulated less than about 150 feet below land surface. The quality of base flow in streams is affected by the residence time of water in the aquifer; old groundwater that has followed a long flow path tends to have higher concentrations of dissolved solids than recently recharge groundwater (Back and others, 1993, p. 117). On the basis of hydrograph separation 


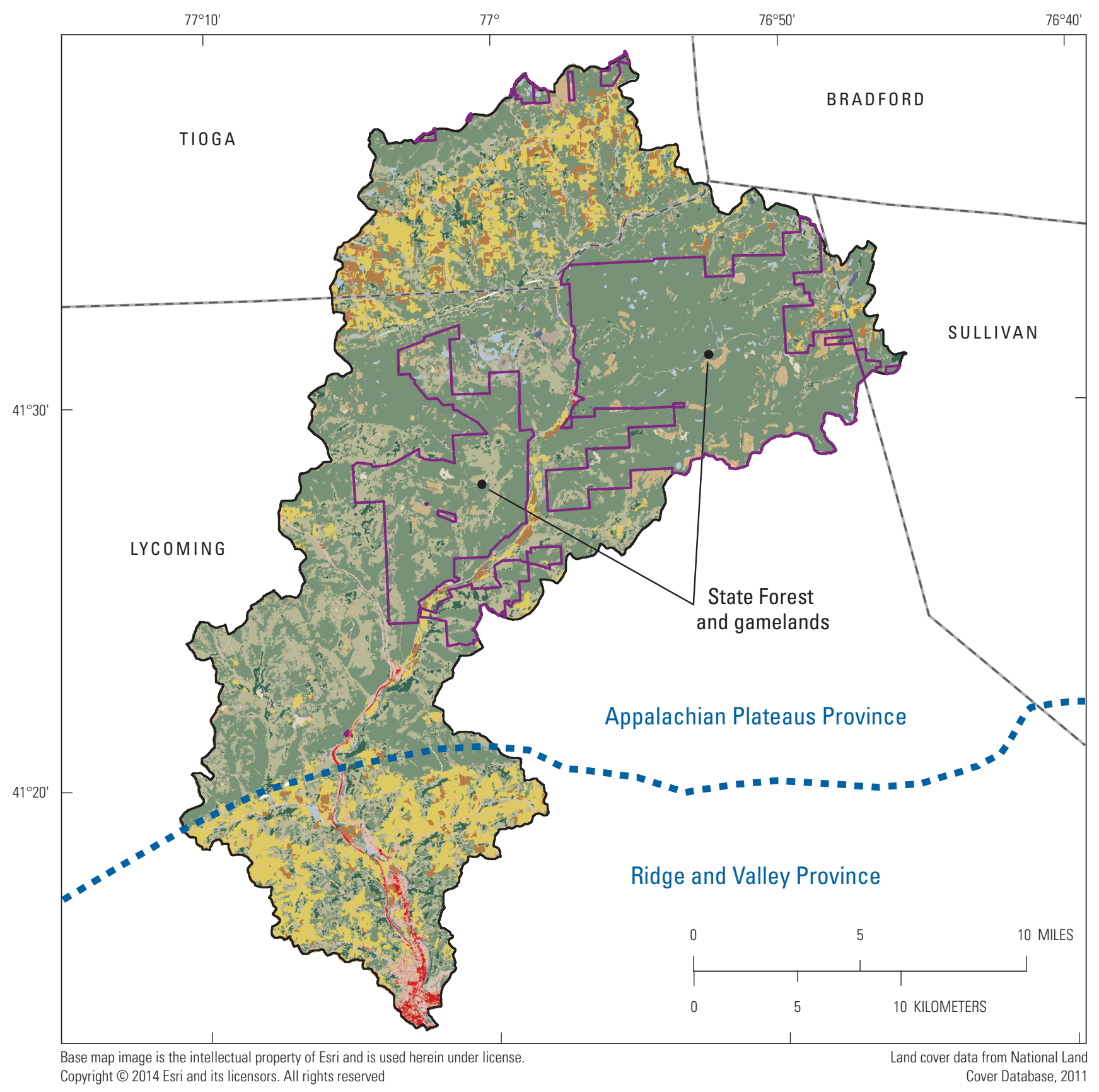

EXPLANATION

\begin{tabular}{|l|l|l|}
\hline Open water & Barren land & Grassland/ herbaceous \\
\hline Developed, open space & Deciduous forest & Pasture/ hay \\
\hline Developed, low intensity & Evergreen forest & Cultivated crops \\
\hline Developed, medium intensity & Mixed forest & Woody wetlands \\
\hline Developed, high intensity & Shrub/scrub & Emergent herbaceous wetlands \\
\hline
\end{tabular}

Figure 4. Land cover as shown in the 2011 National Land Cover Database within the Lycoming Creek watershed in north-central Pennsylvania. 
Table 3. Land cover and use upstream of each sampling location in the Lycoming Creek watershed, north-central Pennsylvania.

[USGS, U.S. Geological Survey; St., street; --, land use category not present; shading indicates basin having greater than 10 percent of land use in that category]

\begin{tabular}{|c|c|c|c|c|c|c|c|c|c|}
\hline \multirow{2}{*}{$\begin{array}{l}\text { Map } \\
\text { identifier }\end{array}$} & \multirow[b]{2}{*}{ USGS station name } & \multicolumn{6}{|c|}{$\begin{array}{c}\text { Percent of basin area } \\
\text { (shaded where value exceeds } 10 \text { percent) }\end{array}$} & \multirow{2}{*}{$\begin{array}{l}\text { Marcellus gas } \\
\text { wells drilled } \\
\text { (number and } \\
\text { density per } \\
\text { square mile) }{ }^{1}\end{array}$} & \multirow{2}{*}{$\begin{array}{l}\text { Historical } \\
\text { coal mining } \\
\text { in water- } \\
\text { shed? }\end{array}$} \\
\hline & & Water & Developed & Barren & Forest & $\begin{array}{c}\text { Pasture } \\
\text { and } \\
\text { crops }\end{array}$ & Wetland & & \\
\hline 1 & Lycoming Creek near Dogtown & 0.07 & 3.36 & -- & 66.17 & 28.79 & 1.61 & $12 / 0.77$ & \\
\hline 2 & $\begin{array}{l}\text { Mill Creek upstream of Roaring } \\
\text { Branch }\end{array}$ & 0.05 & 3.48 & -- & 68.34 & 26.53 & 1.59 & -- & \\
\hline 3 & $\begin{array}{l}\text { Roaring Branch upstream of } \\
\text { Brion Creek near South Union }\end{array}$ & -- & 4.20 & -- & 55.70 & 39.83 & 0.27 & -- & \\
\hline 5 & Salt Spring Run near South Union & 0.03 & 3.86 & -- & 78.86 & 14.71 & 1.23 & $3 / 0.60$ & \\
\hline 6 & $\begin{array}{l}\text { Roaring Branch near Roaring } \\
\text { Branch }\end{array}$ & 0.09 & 3.16 & 0.01 & 62.87 & 32.06 & 1.82 & $1 / 0.13$ & \\
\hline 7 & Red Run at Ralston & 1.55 & 6.63 & 4.94 & 83.33 & 1.05 & 7.44 & $7 / 1.22$ & Yes \\
\hline 8 & Dutchman Run near Ralston & -- & 1.63 & -- & 98.37 & -- & -- & -- & Yes \\
\hline 11 & $\begin{array}{l}\text { Hounds Run at McIntyre Town- } \\
\text { ship }\end{array}$ & -- & -- & -- & 98.82 & 0.10 & 1.08 & -- & \\
\hline 12 & $\begin{array}{l}\text { Rock Run upstream of Lycoming } \\
\text { Creek near Ralston }\end{array}$ & 0.35 & 1.55 & 0.13 & 93.42 & 2.59 & 2.08 & -- & Yes \\
\hline 13 & Frozen Run near Ralston & -- & 2.12 & 1.38 & 94.13 & 0.45 & 3.30 & -- & Yes \\
\hline 14 & North Pleasant Stream at Masten & -- & 2.04 & -- & 83.65 & 14.08 & 0.23 & -- & \\
\hline 15 & Pleasant Stream at Marsh Hill & -- & 0.62 & 0.02 & 95.77 & 2.88 & 0.72 & -- & \\
\hline 16 & Slacks Run at Bodines & -- & 1.92 & 0.50 & 95.02 & 3.06 & -- & $3 / 0.40$ & \\
\hline
\end{tabular}




\section{Surface-Water Quality in the Lycoming Creek Watershed, North-Central Pennsylvania, August 1-3, 2011}

Table 3. Land cover and use upstream of each sampling location in the Lycoming Creek watershed, north-central Pennsylvania.Continued

[USGS, U.S. Geological Survey; St., street; --, land use category not present; shading indicates basin having greater than 10 percent of land use in that category]

\begin{tabular}{|c|c|c|c|c|c|c|c|c|c|}
\hline \multirow{2}{*}{$\begin{array}{l}\text { Map } \\
\text { identifier }\end{array}$} & \multirow[b]{2}{*}{ USGS station name } & \multicolumn{6}{|c|}{$\begin{array}{c}\text { Percent of basin area } \\
\text { (shaded where value exceeds } 10 \text { percent) }\end{array}$} & \multirow{2}{*}{$\begin{array}{l}\text { Marcellus gas } \\
\text { wells drilled } \\
\text { (number and } \\
\text { density per } \\
\text { square mile) }\end{array}$} & \multirow{2}{*}{$\begin{array}{l}\text { Historical } \\
\text { coal mining } \\
\text { in water- } \\
\text { shed? }\end{array}$} \\
\hline & & Water & Developed & Barren & Forest & $\begin{array}{c}\text { Pasture } \\
\text { and } \\
\text { crops }\end{array}$ & Wetland & & \\
\hline 17 & Grays Run near Fields Station & 0.04 & 0.87 & 0.24 & 97.70 & 0.99 & 0.41 & $3 / 0.17$ & \\
\hline 18 & Hagerman Run near Trout Run & -- & 1.93 & 1.66 & 97.82 & 0.25 & -- & -- & \\
\hline 19 & $\begin{array}{l}\text { Trout Run at Route } 15 \text { at Lewis } \\
\text { Township }\end{array}$ & -- & 1.04 & 0.95 & 97.31 & 1.64 & -- & $4 / 0.54$ & \\
\hline 21 & Wolf Run near Trout Run & 0.08 & 2.43 & 1.42 & 97.00 & 0.49 & -- & $3 / 0.15$ & \\
\hline 22 & $\begin{array}{l}\text { Wolf Run upstream of Lycoming } \\
\text { Creek near Trout Run }\end{array}$ & 0.08 & 2.21 & 1.38 & 97.22 & 0.49 & -- & -- & \\
\hline 23 & Daugherty Run near Powys & -- & 1.92 & 0.52 & 95.53 & 2.55 & -- & $1 / 0.07$ & \\
\hline 24 & Lycoming Creek at Haleeka & 0.12 & 2.89 & 0.46 & 84.87 & 10.77 & 1.35 & -- & \\
\hline 27 & Mill Creek near Hepburnville & 0.02 & 5.01 & 0.24 & 48.98 & 45.78 & 0.21 & $5 / 0.45$ & \\
\hline 28 & Beautys Run near Hepburnville & -- & 4.45 & -- & 45.69 & 49.86 & -- & -- & \\
\hline 29 & Lycoming Creek near Heshbon & 0.11 & 3.69 & 0.45 & 80.14 & 14.82 & 1.23 & -- & \\
\hline 30 & Bottle Run near Williamsport & 0.05 & 11.41 & -- & 50.13 & 37.56 & 0.85 & -- & \\
\hline 31 & $\begin{array}{l}\text { Lycoming Creek at 3rd St. bridge } \\
\text { at Williamsport }\end{array}$ & 0.12 & 4.60 & 0.43 & 78.97 & 15.07 & 1.23 & -- & \\
\hline
\end{tabular}

${ }^{1}$ Not computed for four sites on the main stem of Lycoming Creek below Dogtown. 


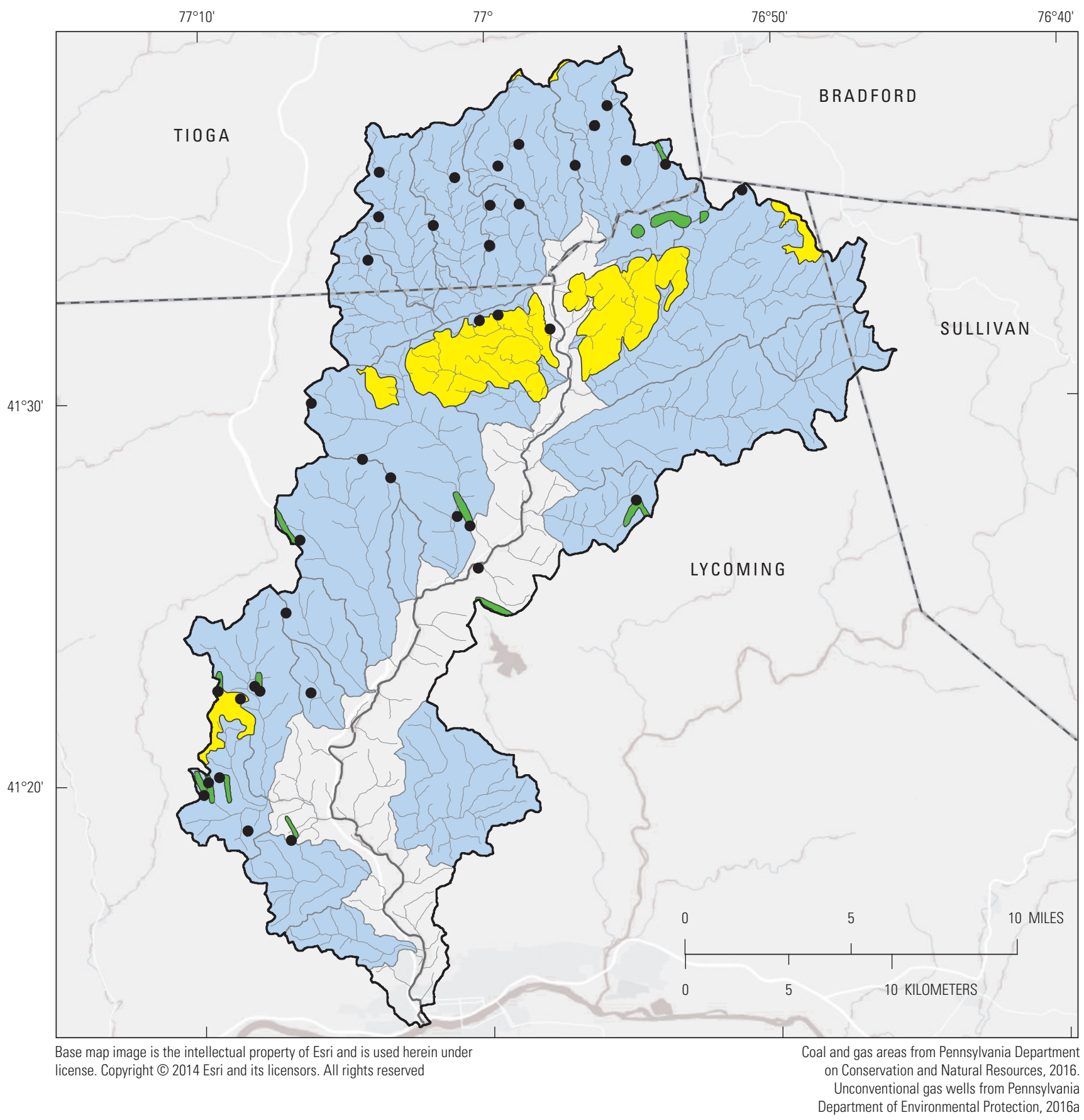

EXPLANATION

Oil and gas pools boundary

Bituminous coal boundary

Tributary watershed boundary

- Unconventional gas wells

Figure 5. Underlying bituminous coalbeds and oil and gas pools in the Lycoming Creek watershed in north-central Pennsylvania. Unconventional gas wells were drilled before August 1, 2011. 
(Risser and others, 2005), groundwater discharge to Lycoming Creek near Trout Run provided about two-thirds of the total flow in the stream during 1930-2001.

\section{Methods}

Surface water was sampled by the USGS and PaDEP during August 1-3, 2011 at 31 locations in Lycoming Creek watershed. The process of selecting the sampling sites, collecting and analyzing the water samples, and assessing the quality of the data is described in this section.

\section{Site Selection}

Surface-water sites were selected in coordination with WMWA and PaDEP. Eleven sites in the watershed were already established and were being sampled in 2011 by PaDEP for a regulatory program. Those sites and others locations were visited in the field with WMWA and 31 sites in total were selected for sampling (fig. 1 and table 1). Five sampling sites were on the main stem of Lycoming Creek. The watershed areas for the main-stem sites ranged from $15.6 \mathrm{mi}^{2}$ for the most upstream site near Dogtown to $272 \mathrm{mi}^{2}$ for the most downstream site at the 3rd Street Bridge near the mouth of Lycoming Creek. The other 26 sampling sites were located on 22 tributary streams. Four of the tributaries-Roaring Branch, Rock Run, Trout Run, and Wolf Run-were each sampled at two sites. Watersheds areas ranged from 1.1 to $30.5 \mathrm{mi}^{2}$ for the tributary streams that were sampled.

Sampling sites on tributary streams were selected to represent watersheds with various land uses (forest, agriculture, resource extraction, urban development) and underlying geology (tables 2 and 3). Samples from these streams provide a preliminary survey of base-flow water quality for those settings. Streams were sampled throughout the watershed to identify the chemical signatures of water in tributaries draining differing land uses and geology.

\section{Sample Collection}

The surface-water samples were collected during a relatively dry period August 1-3, 2011, during base-flow conditions. At the beginning of sample collection on August 1, 2011, streamflow in Lycoming Creek near Trout Run (USGS streamgage 01550000) was 21 cubic feet per second (ft3/s) (fig. 6). Lower flows were recorded at that streamgage only about 10 percent of the time during 100 years of record; although some soil interflow may be contributing, at this lowflow condition samples represent predominantly groundwater discharge to streams. A low, base-flow condition was targeted for sampling because the WMWA wells are only used during dry months to supplement the surface-water from sources located south of the West Branch Susquehanna River; thus, the reconnaissance sampling was timed to occur during the typical conditions when the well field would be in operation and have the potential to capture infiltration from Lycoming Creek.

All environmental and quality-assurance samples were collected by three crews during a 48-hour period between August 1, 2011, at 10:30 a.m. and August 3, 2011, at 10:30 a.m. Although not expected, scattered storms moved across northern Pennsylvania during the sampling period. Neither precipitation nor turbid stream water were reported by the crews during sample collection at any of the sites, but the USGS streamgage on Lycoming Creek near Trout Run did show that the flow in Lycoming Creek changed during the hours when samples were collected (fig. 7). At the time when the first sample was collected (August 1 at 10:30 a.m.) flow was $21 \mathrm{ft}^{3} / \mathrm{s}$; the flow peaked at $29 \mathrm{ft}^{3} / \mathrm{s}$ between August 2 at 8:45PM and August 3 at 8:00AM, and then fell to $27 \mathrm{ft}^{3} / \mathrm{s}$ when the last sample was collected on August 3 at 10:30 a.m.

The extent to which changes in streamflow could have affected the chemical quality of the water is not known, but it is probably small. The increase in flow from 21 to $29 \mathrm{ft}^{3} / \mathrm{s}$ is not a storm peak; it still represents low flow in Lycoming Creek that has historically been lower only about 11 percent of the time. Also, based on multiple samples collected during different flow conditions in Lycoming Creek near Trout Run, a change in streamflow from the measured flow of 21 to $29 \mathrm{ft}^{3} / \mathrm{s}$ would be expected to only decrease specific conductance from about 83 to $80 \mu \mathrm{S} / \mathrm{cm}$ at 25 degrees Celsius (fig. 8 ).

Surface-water samples were collected by both USGS and PaDEP personnel. Although the sample-collection was coordinated, sampling protocols used by the agencies differed. USGS personnel collected environmental samples at 20 sites (table 1) and processed them using standard field methods of the U.S. Geological Survey (U.S. Geological Survey, variously dated). Each sample was collected using the equal-width increment (EWI) method, in which aliquots of water are collected across the stream with vertical transects at each increment and mixed in a polyethylene churn. Sample bottles were filled by drawing the composite water from the churn with a peristaltic pump and filtering through a 0.45 -micron capsule filter. Samples were preserved with acid and chilled (if necessary), and shipped overnight to the appropriate laboratory under chain-of-custody protocols.

PaDEP personnel collected environmental surface-water samples at the 11 sites that they had previously established (table 1) by wading to near the centroid of flow in the stream and filling sample bottles by dipping them below the water surface at a single depth. Samples were not acidified or filtered in the field. They were chilled (if necessary), and delivered to the PaDEP laboratory by courier under chain-of-custody protocols.

Quality-assurance samples were collected at five sites (table 1) by both USGS and PaDEP personnel to evaluate the effects of different sample-collection protocols and laboratories used to analyze the water chemistry. Replicate samples were taken by USGS and PaDEP personnel using the EWI and single-point methods, respectively, and these samples were sent to both the USGS and PaDEP laboratories to compare results. 


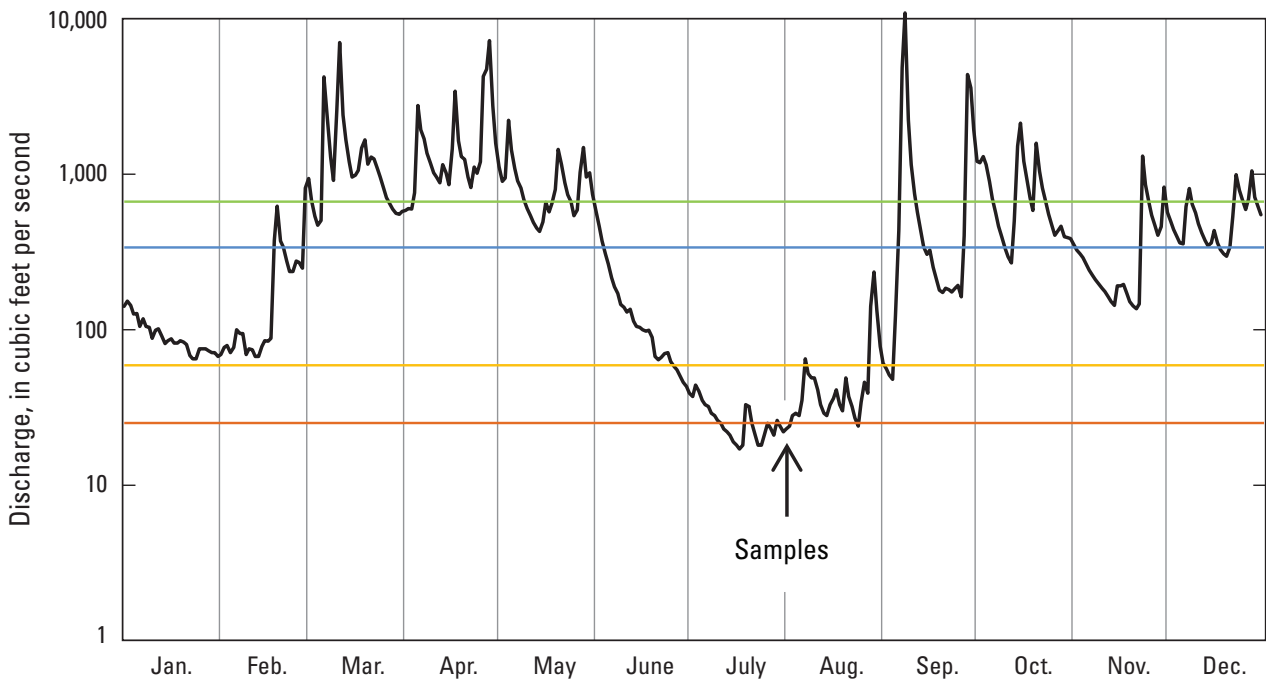

EXPLANATION

Percentiles

- p90

- p75

$-p 25$

Figure 6. Hydrograph of Lycoming Creek near Trout Run at USGS streamgage 01550000 , showing streamflow conditions when water samples were taken in relation to streamflow during 2011 and to streamflow recorded at the streamgage from 1913 to 2014.

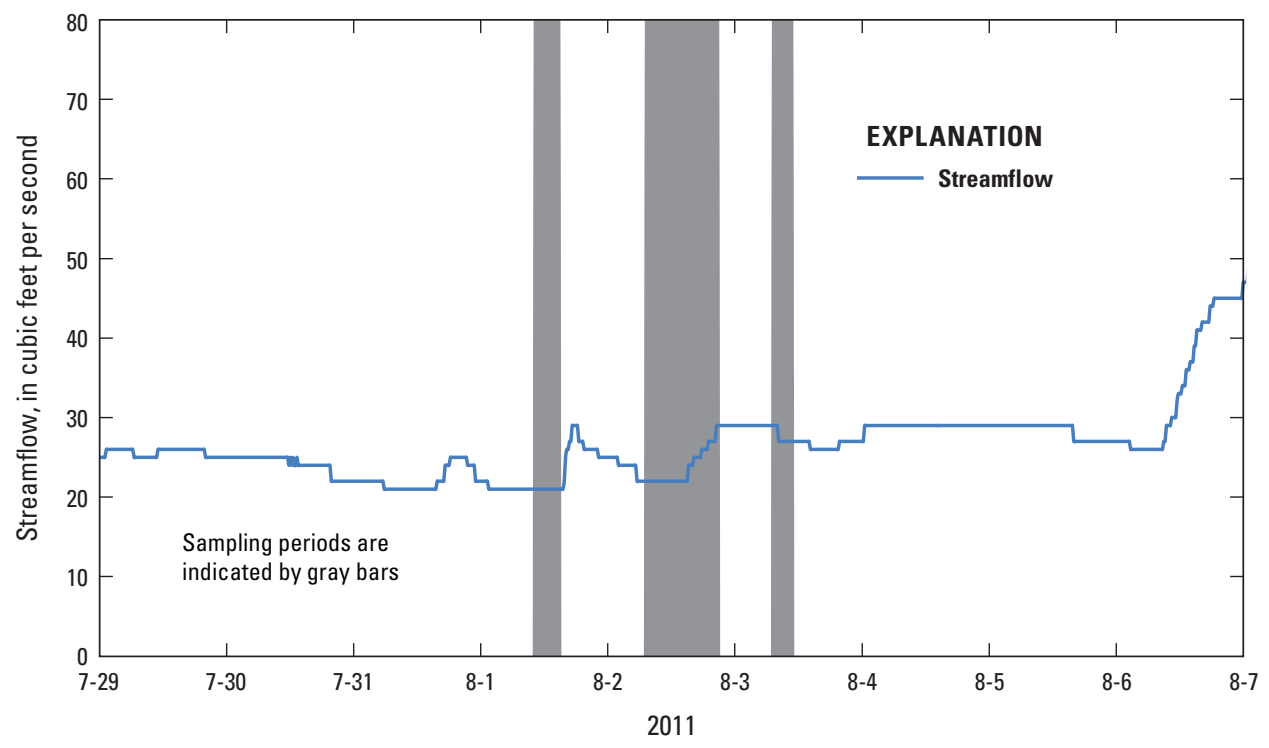

Figure 7. Streamflow in Lycoming Creek near Trout Run recorded at USGS streamgage 01550000, and periods when stream samples were collected in the Lycoming Creek watershed, August 1-3, 2011. 


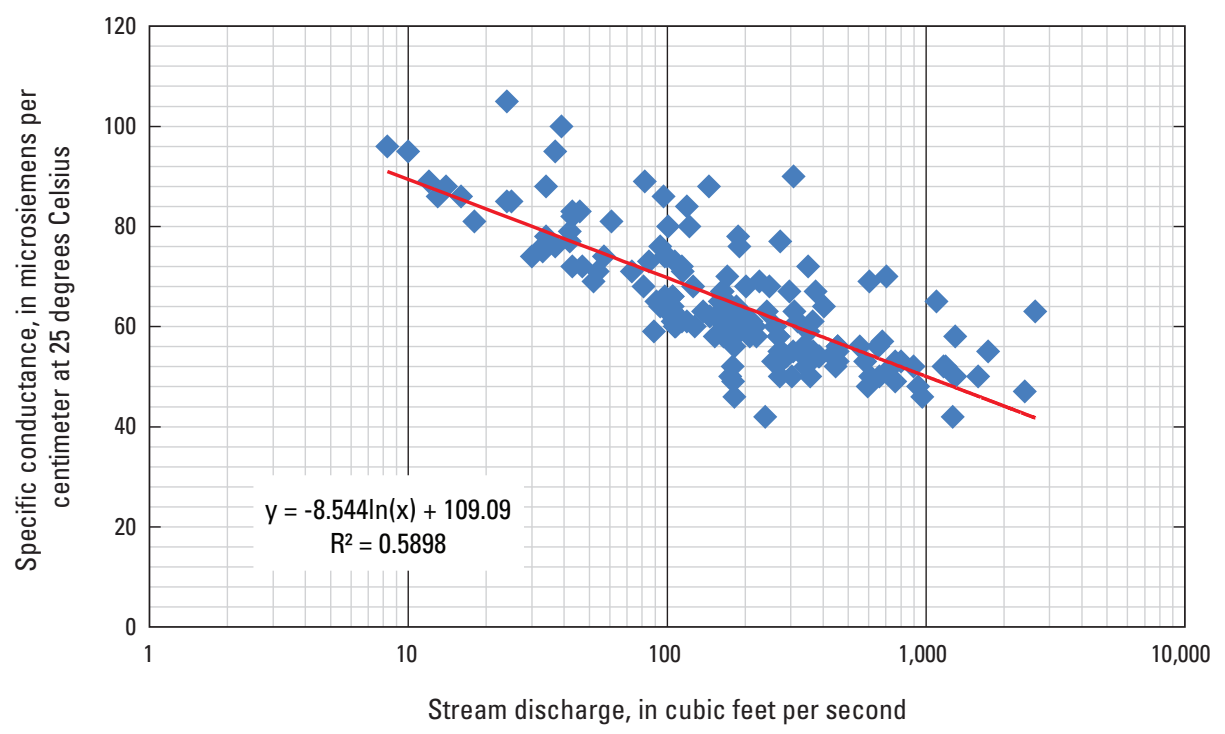

Figure 8. Stream discharge and specific conductance of 160 samples collected at Lycoming Creek near Trout Run for the Pennsylvania Water-Quality Network during 1975-2015.

\section{Sample Analysis}

Water samples collected by USGS were analyzed for field parameters, major ions, nutrients, trace metals, and radiochemicals. The $\mathrm{pH}$, water temperature, specific conductance, and dissolved oxygen were measured in the stream with a multiparameter meter. Turbidity was measured in the field with a portable turbidity meter. Acid neutralizing capacity was titrated either in the field at the time of sample collection or at the end of the day. USGS personnel measured stream discharge at each location at the time of sample collection. For analysis of major ions, nutrients, and trace metals, water samples were sent to the USGS National Water Quality Laboratory (NWQL) in Denver, Colo. Samples for radiochemicals were sent Eberline Services Inc., a private laboratory under contract to the NWQL. The NWQL is certified by the National Environmental Laboratory Accreditation Program (NELAP) for analysis of nonpotable waters by USGS methods. Details about the NWQL accreditations, laboratory audits, and proficiency testing are available online at http://nwql.usgs.gov/ quality.shtml. The Eberline Services, Inc., laboratory is also certified by the EPA.

Water samples collected by PaDEP were analyzed for major ions, nutrients, and trace metals. Samples were sent to the PaDEP laboratory in Harrisburg, Pa. The PaDEP laboratory is certified by NELAP for analytical testing of drinking water and nonpotable water and it participates in the USGS Standard Reference Sample Project (U.S. Geological Survey, 2016b).

\section{Reporting Limits}

The reporting limits for the analytical methods requested from the USGS NWQL and PaDEP laboratory differed for all of the water-quality constituents analyzed in this study (table 4). For the nutrients, the reporting limits were similar. Reporting limits differed substantially for trace metals and some major constituents. In some cases, the differences were greater than one order of magnitude. For example, the USGS NQWL reporting limit for sulfate was 0.09 milligrams per liter $(\mathrm{mg} / \mathrm{L})$, and the PaDEP laboratory reporting limit was $15 \mathrm{mg} / \mathrm{L}$. As a result, for some water-quality constituents, there are instances where most or all of the 20 sites sampled by USGS have values greater than the reporting level, but all 11 sites sampled by PaDEP are censored as less than the reporting level. The discussion of results for many of the trace metals is limited to the 20 USGS sample sites because of these differences. 
Table 4. Comparison of water-quality constituents analyzed by the Pennsylvania Department of Environmental Protection and U.S. Geological Survey laboratories and reporting limits for samples collected from streams in the Lycoming Creek watershed, north-central Pennsylvania, August 1-3, 2011.

[Shading indicates constituents analyzed by both laboratories. USGS, U.S. Geological Survey; PaDEP, Pennsylvania Department of Environmental Protection; $\mathrm{mg} / \mathrm{L}$, milligrams per liter; $\mu \mathrm{g} / \mathrm{L}$, micrograms per liter; $\mathrm{pCi} / \mathrm{L}$, picocuries per liter; NA; not analyzed]

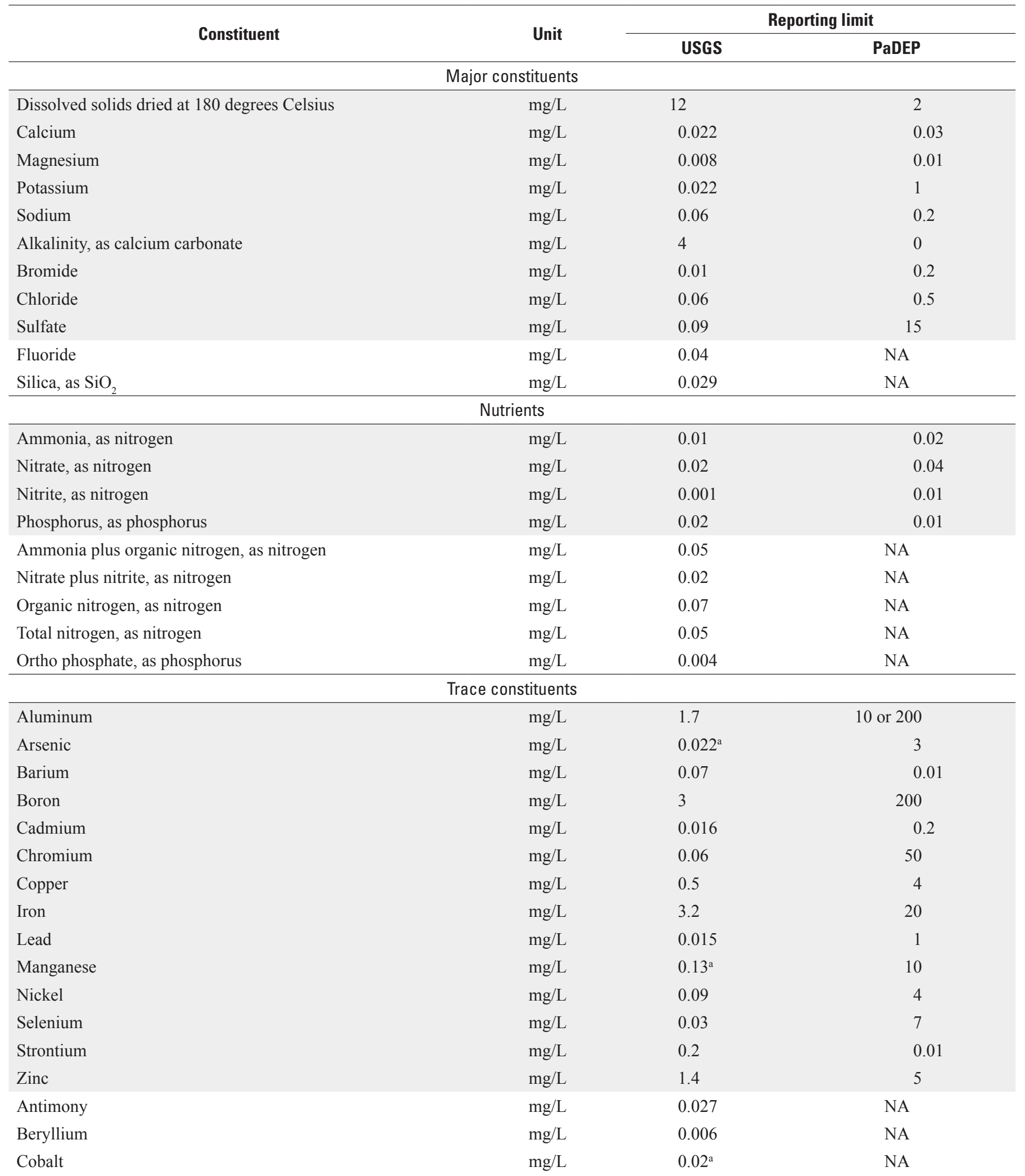


Table 4. Comparison of water-quality constituents analyzed by the Pennsylvania Department of Environmental Protection and U.S. Geological Survey laboratories and reporting limits for samples collected from streams in the Lycoming Creek watershed, north-central Pennsylvania, August 1-3, 2011.-Continued

[Shading indicates constituents analyzed by both laboratories. USGS, U.S. Geological Survey; PaDEP, Pennsylvania Department of Environmental Protection; $\mathrm{mg} / \mathrm{L}$, milligrams per liter; $\mu \mathrm{g} / \mathrm{L}$, micrograms per liter; $\mathrm{pCi} / \mathrm{L}$, picocuries per liter; NA; not analyzed]

\begin{tabular}{|c|c|c|c|}
\hline \multirow{2}{*}{ Constituent } & \multirow{2}{*}{ Unit } & \multicolumn{2}{|c|}{ Reporting limit } \\
\hline & & USGS & PaDEP \\
\hline Lithium & $\mathrm{mg} / \mathrm{L}$ & 0.22 & NA \\
\hline Silver & $\mathrm{mg} / \mathrm{L}$ & 0.005 & NA \\
\hline Uranium (natural) & $\mathrm{mg} / \mathrm{L}$ & 0.004 & NA \\
\hline Alpha radioactivity, 30-day count & $\mathrm{pCi} / \mathrm{L}$ & 3 & NA \\
\hline Alpha radioactivity, 72-hour count & $\mathrm{pCi} / \mathrm{L}$ & 3 & NA \\
\hline Beta radioactivity, 30-day count & $\mathrm{pCi} / \mathrm{L}$ & 4 & NA \\
\hline Beta radioactivity, 72-hour count & $\mathrm{pCi} / \mathrm{L}$ & 4 & NA \\
\hline
\end{tabular}

${ }^{a}$ Reporting limits for the project were raised to five times the concentration found in the blank sample for cobalt $(0.39 \mathrm{mg} / \mathrm{L}), \mathrm{manganese}(0.85 \mathrm{mg} / \mathrm{L})$, and $\operatorname{arsenic}(0.15 \mathrm{mg} / \mathrm{L})$.

\section{Quality Assurance}

Quality-assurance samples were collected to evaluate possible contamination, accuracy of laboratory results, reproducibility of results, and possible bias caused by the different sampling protocols and laboratories used by USGS and PaDEP. This was done by the analysis of blanks, standardreference samples, replicate samples, and duplicate samples collected at the same site by different methods. Analytical results for quality assurance samples are presented in tables; results are also available online in the USGS NWIS (U.S. Geological Survey, 2017).

\section{Blank and Standard Reference Samples}

Reagent-grade inorganic-free blank water was poured into a polyethylene churn and processed in the field at the Bottle Run site using standard USGS surface-water quality sampling procedures. The blank sample was analyzed by NWQL for major ions, trace metals, and nutrients. The laboratory results showed that concentrations were below reporting levels for all constituents except for cobalt, manganese, and arsenic. Those constituents were present in the blank water at $0.078,0.17$, and 0.03 micrograms per liter $(\mu \mathrm{g} / \mathrm{L})$, respectively (table 5 ). The detections indicate that concentrations reported by the NWQL at those low levels in the environmental surface-water samples might be affected by contamination introduced during the sampling or analytical process. For this study the reporting limits for cobalt, manganese, and arsenic found in the environmental samples were increased to five times the concentration found in the blank for those constituents, following guidelines cited in Mueller and others (2015, p. 19). The reported concentrations for cobalt in 13 samples, manganese in 3 samples, and arsenic in 4 samples were below the five-times threshold, so they were treated as nondetections.

One standard-reference water sample was processed in the field at the site on Slacks Run (site 16) by transferring standard-reference water into sample bottles used for the environmental samples. The standard-reference water was obtained from the NWQL Bureau of Quality Systems. It had been analyzed by many different laboratories and given a certified most-probable value and range of uncertainty for each constituent. The standard-reference sample was sent to the NWQL to evaluate accuracy for analyzing major cations, nutrients, and trace metals. Results for all constituents were acceptable with the exception of silica, nitrate plus nitrite, iron, lithium, and boron, which were noted by the NWQL Bureau of Quality Systems as being outside of two f-pseudosigmas (a statistically robust approximation of the standard deviation) from the most probable values for those constituents (table 6). These results indicate a possible high bias of values from NWQL for silica, nitrate plus nitrite, and lithium; and low bias for iron and boron. The possible bias was noted as a project data-quality indicator on the table of analytical results.

\section{Replicate Samples}

Replicate samples were obtained as aliquots of the same water composited in the sample churn at a site. Replicates were collected at Dutchman Run (site 8) and Hounds Run (site 11) to evaluate the reproducibility of results for samples collected by USGS personnel and sent to NWQL for analysis of major ions, nutrients, and trace metals (table 7). Results were reproduced within acceptable limits (differences less than 25 percent) for all constituents in the sample from Dutchman 
Table 5. Concentrations reported by the U.S. Geological Survey National Water Quality Laboratory for the inorganic blank water sample (field equipment black).

[Value in parentheses is the parameter code, a unique 5-digit number used by the U.S. Geological Survey to identify a constituent; <, less than. Dark shading highlights constituents that were detected in the blank]

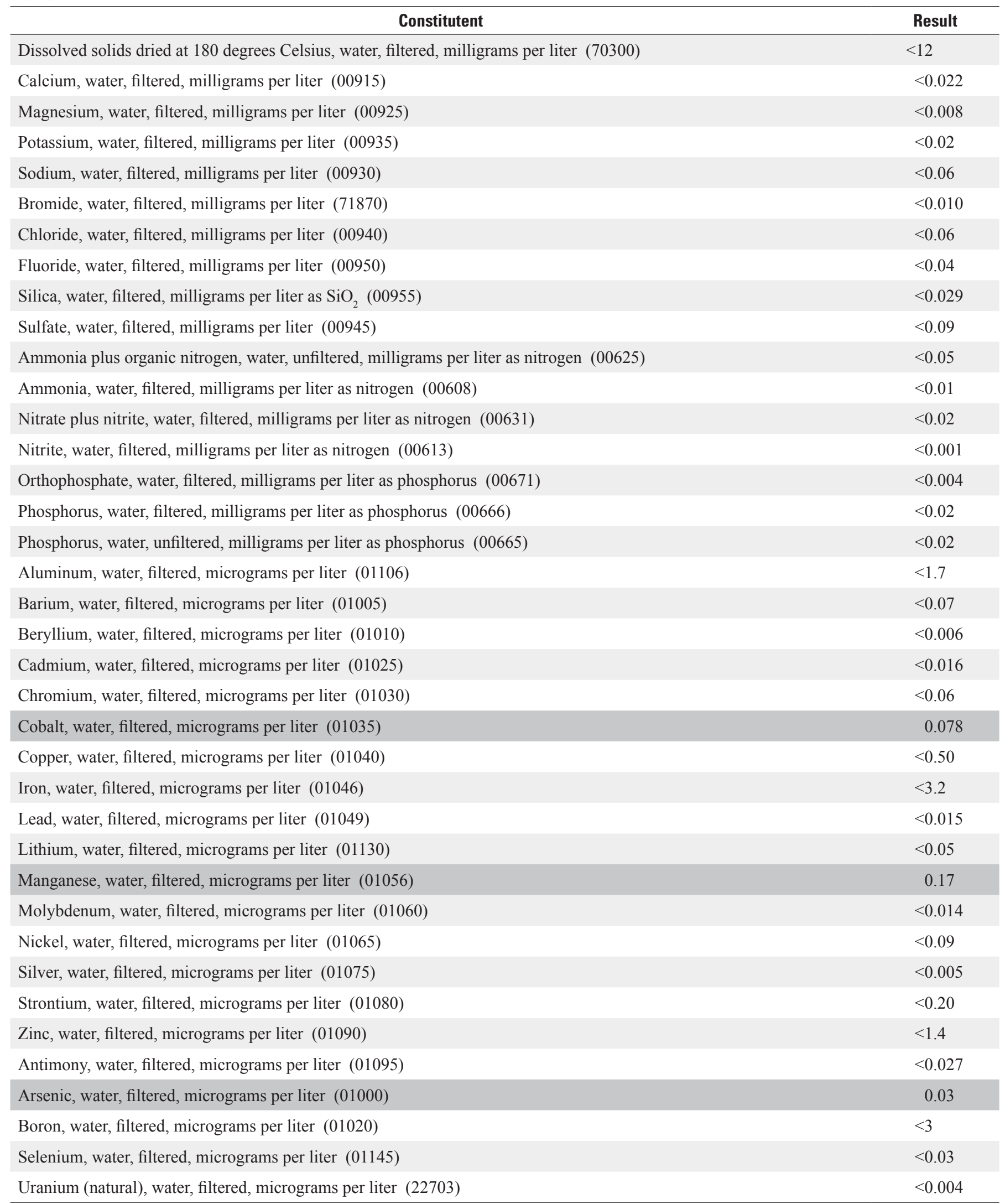


Table 6. Comparison of concentrations reported by the U.S. Geological Survey National Water Quality Laboratory to expected values for the standard reference samples T-181 (trace metals) and N-109 (nutrients).

[Value in parentheses is the parameter code, a unique 5-digit number used by the U.S. Geological Survey to identify a constituent; Most probable value is the median value for an analyte determimed by multiple laboratories participating in the blind sample quality assurace program; NWQL, U.S. Geological Survey National Water Quality Laboratory; Percent difference $=100 *((\mathrm{NWQL}$ result - Most probable value)/Most probable value). Dark shading indicates the result is outside of the acceptable deviation from the most probable value. Acceptable deviation is two f-pseudosigmas (a statistically robust approximation of the standard deviation) from the most probable value]

\begin{tabular}{|c|c|c|c|}
\hline Constitutent & $\begin{array}{l}\text { Most probable } \\
\text { value }\end{array}$ & $\begin{array}{l}\text { NWOL } \\
\text { result }\end{array}$ & $\begin{array}{c}\text { Percent } \\
\text { difference }\end{array}$ \\
\hline Calcium, water, filtered, milligrams per liter (00915) & 13.4 & 13.6 & 1.5 \\
\hline Magnesium, water, filtered, milligrams per liter (00925) & 3.05 & 3.26 & 6.9 \\
\hline Potassium, water, filtered, milligrams per liter (00935) & 1.52 & 1.51 & -0.7 \\
\hline Sodium, water, filtered, milligrams per liter (00930) & 15 & 15.2 & 1.3 \\
\hline Silica, water, filtered, milligrams per liter as $\mathrm{SiO}_{2}(00955)$ & 13.1 & 14.2 & 8.4 \\
\hline Ammonia, water, filtered, milligrams per liter as nitrogen (00608) & 0.195 & 0.19 & -2.6 \\
\hline Nitrate plus nitrite, water, filtered, milligrams per liter as nitrogen (00631) & 0.191 & 0.21 & 9.9 \\
\hline Orthophosphate, water, filtered, milligrams per liter as phosphorus (00671) & 0.193 & 0.2 & 3.6 \\
\hline Aluminum, water, filtered, micrograms per liter (01106) & 16.2 & 16.6 & 2.5 \\
\hline Barium, water, filtered, micrograms per liter (01005) & 25.5 & 24.2 & -5.1 \\
\hline Beryllium, water, filtered, micrograms per liter (01010) & 4.6 & 4.07 & -12 \\
\hline Cadmium, water, filtered, micrograms per liter (01025) & 1.6 & 1.68 & 5.0 \\
\hline Chromium, water, filtered, micrograms per liter (01030) & 5.64 & 5.5 & -2.5 \\
\hline Cobalt, water, filtered, micrograms per liter (01035) & 5.5 & 5.38 & -2.2 \\
\hline Copper, water, filtered, micrograms per liter (01040) & 7.79 & 7.5 & -3.7 \\
\hline Iron, water, filtered, micrograms per liter (01046) & 119 & 68.9 & -42 \\
\hline Lead, water, filtered, micrograms per liter (01049) & 9.4 & 9.2 & -2.1 \\
\hline Lithium, water, filtered, micrograms per liter (01130) & 8.4 & 9.75 & 16.0 \\
\hline Manganese, water, filtered, micrograms per liter (01056) & 11.6 & 12.2 & 5.2 \\
\hline Molybdenum, water, filtered, micrograms per liter (01060) & 4.49 & 4.62 & 2.9 \\
\hline Nickel, water, filtered, micrograms per liter (01065) & 4.72 & 4.8 & 1.7 \\
\hline Silver, water, filtered, micrograms per liter (01075) & 4.3 & 4.26 & -0.9 \\
\hline Strontium, water, filtered, micrograms per liter (01080) & 81.6 & 84.6 & 3.7 \\
\hline Zinc, water, filtered, micrograms per liter (01090) & 10.5 & 10.8 & 2.9 \\
\hline Antimony, water, filtered, micrograms per liter (01095) & 3.43 & 3.26 & -5.0 \\
\hline Arsenic, water, filtered, micrograms per liter $(01000)$ & 6.1 & 6.6 & 8.2 \\
\hline Boron, water, filtered, micrograms per liter (01020) & 21 & 16 & -24 \\
\hline Selenium, water, filtered, micrograms per liter (01145) & 1.3 & 1.3 & 0.0 \\
\hline Uranium (natural), water, filtered, micrograms per liter (22703) & 1.85 & 1.84 & -0.5 \\
\hline
\end{tabular}


Table 7. Concentrations reported by the U.S. Geological Survey National Water Quality Laboratory for replicate samples collected from two streams in the Lycoming Creek watershed, north-central Pennsylvania, August 1-3, 2011.

$[\mathrm{mg} / \mathrm{L}$, milligrams per liter; $\mu \mathrm{g} / \mathrm{L}$, micrograms per liter; N, nitrogen; P, phosphorus; PA, Pennsylvania; Twp, township; <, less than; --, not determined; positive percent difference indicates replicate value is larger than environmental sample. All samples were filtered in the field unless noted]

\begin{tabular}{|c|c|c|c|c|c|c|}
\hline \multirow[b]{2}{*}{ Constituent and USGS parameter code } & \multicolumn{3}{|c|}{ Dutchman Run near Ralston, PA } & \multicolumn{3}{|c|}{ Hounds Run at McIntyre Twp, PA } \\
\hline & $\begin{array}{c}\text { Environ- } \\
\text { mental } \\
\text { sample } \\
\text { 8/2/11 20:30 }\end{array}$ & $\begin{array}{l}\text { Replicate } \\
\text { sample } \\
8 / 2 / 11 \text { 20:31 }\end{array}$ & $\begin{array}{c}\text { Percent } \\
\text { difference }\end{array}$ & $\begin{array}{c}\text { Environ- } \\
\text { mental } \\
\text { sample } \\
\text { 8/2/11 19:00 }\end{array}$ & $\begin{array}{l}\text { Replicate } \\
\text { sample } \\
\text { 8/2/11 19:01 }\end{array}$ & $\begin{array}{c}\text { Percent } \\
\text { difference }\end{array}$ \\
\hline Dissolved solids dried at 180 degrees Celsius, mg/L (70300) & 191 & 182 & -4.8 & 14.0 & 17.0 & 19.4 \\
\hline Calcium, mg/L (00915) & 9.34 & 9.37 & 0.3 & 2.12 & 2.15 & 1.4 \\
\hline Magnesium, mg/L (00925) & 9.79 & 9.78 & -0.1 & 0.637 & 0.635 & -0.3 \\
\hline Potassium, mg/L (00935) & 1.07 & 1.09 & 1.9 & 0.32 & 0.35 & 9.0 \\
\hline Sodium, mg/L (00930) & 1.01 & 1.02 & 1.0 & 0.58 & 0.59 & 1.7 \\
\hline Bromide, mg/L (71870) & $<0.01$ & $<0.01$ & -- & 0.015 & 0.015 & 0.0 \\
\hline Chloride, mg/L (00940) & 0.28 & 0.30 & 6.9 & 0.53 & 0.54 & 1.9 \\
\hline Fluoride, mg/L (00950) & 0.09 & 0.08 & -11.8 & $<0.04$ & $<0.04$ & -- \\
\hline Silica, mg/L as $\mathrm{SiO}_{2}$ (00955) & 20.7 & 20.5 & -1.0 & 4.42 & 4.39 & -0.7 \\
\hline Sulfate, $\mathrm{mg} / \mathrm{L}(00945)$ & 130 & 131 & 0.8 & 6.51 & 6.87 & 5.4 \\
\hline Ammonia plus organic nitrogen, unfiltered, $\mathrm{mg} / \mathrm{L}$ as $\mathrm{N}(00625)$ & $<0.05$ & 0.15 & -- & $<0.05$ & $<0.05$ & -- \\
\hline Ammonia, $\mathrm{mg} / \mathrm{L}$ as N (00608) & $<0.01$ & 0.02 & -- & $<0.01$ & $<0.01$ & -- \\
\hline Nitrate plus nitrite, $\mathrm{mg} / \mathrm{L}$ as $\mathrm{N}(00631)$ & 0.06 & 0.06 & 0.0 & 0.33 & 0.33 & 0.0 \\
\hline Nitrite, $\mathrm{mg} / \mathrm{L}$ as N (00613) & $<0.001$ & $<0.001$ & -- & $<0.001$ & $<0.001$ & -- \\
\hline Orthophosphate, $\mathrm{mg} / \mathrm{L}$ as $\mathrm{P}$ (00671) & 0.005 & 0.004 & -22.2 & $<0.004$ & $<0.004$ & -- \\
\hline Phosphorus, mg/L as P (00666) & $<0.02$ & $<0.02$ & -- & $<0.02$ & $<0.02$ & -- \\
\hline Phosphorus, unfiltered, mg/L as P (00665) & $<0.02$ & $<0.02$ & -- & $<0.02$ & $<0.02$ & -- \\
\hline Aluminum, $\mu \mathrm{g} / \mathrm{L}$ (01106) & 4,950 & 4,810 & -2.9 & 27.8 & 21.2 & -26.9 \\
\hline Barium, $\mu \mathrm{g} / \mathrm{L}(01005)$ & 32.3 & 31.9 & -1.2 & 21.9 & 21.9 & 0.0 \\
\hline Beryllium, $\mu \mathrm{g} / \mathrm{L}$ (01010) & 3.38 & 3.77 & 10.9 & 0.063 & 0.063 & 0.0 \\
\hline Cadmium, $\mu \mathrm{g} / \mathrm{L}$ (01025) & 0.452 & 0.463 & 2.4 & 0.105 & 0.101 & 3.9 \\
\hline Chromium, $\mu \mathrm{g} / \mathrm{L}$ (01030) & 1.0 & 0.99 & 1.0 & $<0.06$ & $<0.06$ & -- \\
\hline Cobalt, $\mu \mathrm{g} / \mathrm{L}$ (01035) & 45.1 & 45.2 & 0.2 & 0.043 & 0.024 & 56.7 \\
\hline Copper, $\mu \mathrm{g} / \mathrm{L}$ (01040) & 20.5 & 20.4 & 0.5 & 0.68 & $<0.50$ & -- \\
\hline Iron, $\mu \mathrm{g} / \mathrm{L}(01046)$ & 498 & 495 & 0.6 & 4.7 & $<3.2$ & -- \\
\hline Lead, $\mu \mathrm{g} / \mathrm{L}$ (01049) & 4.06 & 4.09 & 0.7 & 0.028 & 0.016 & 54.5 \\
\hline Lithium, $\mu \mathrm{g} / \mathrm{L}$ (01130) & 49.2 & 47.6 & 3.3 & 0.91 & 0.91 & 0.0 \\
\hline Manganese, $\mu \mathrm{g} / \mathrm{L}$ (01056) & 1,770 & 1,780 & 0.6 & 6.13 & 6.9 & 11.8 \\
\hline Molybdenum, $\mu \mathrm{g} / \mathrm{L}$ (01060) & $<0.014$ & $<0.014$ & -- & $<0.014$ & $<0.014$ & -- \\
\hline Nickel, $\mu \mathrm{g} / \mathrm{L}(01065)$ & 90.2 & 90 & 0.2 & 2.1 & 2 & 4.9 \\
\hline Silver, $\mu \mathrm{g} / \mathrm{L}(01075)$ & $<0.005$ & $<0.005$ & -- & $<0.005$ & $<0.005$ & -- \\
\hline Strontium, $\mu \mathrm{g} / \mathrm{L}$ (01080) & 44.9 & 43.7 & 2.7 & 19.5 & 19.7 & 1.0 \\
\hline Zinc, $\mu \mathrm{g} / \mathrm{L}(01090)$ & 190 & 189 & 0.5 & 8.8 & 8.8 & 0.0 \\
\hline Antimony, $\mu \mathrm{g} / \mathrm{L}$ (01095) & $<0.027$ & $<0.027$ & -- & $<0.027$ & $<0.027$ & -- \\
\hline Arsenic, $\mu \mathrm{g} / \mathrm{L}(01000)$ & 0.20 & 0.23 & 14.0 & 0.08 & 0.07 & 13.3 \\
\hline Boron, $\mu \mathrm{g} / \mathrm{L}(01020)$ & 5 & 5 & 0.0 & 4 & 4 & 0.0 \\
\hline Selenium, $\mu \mathrm{g} / \mathrm{L}$ (01145) & 0.83 & 0.8 & 3.7 & 0.06 & 0.05 & 18.2 \\
\hline Uranium (natural), $\mu \mathrm{g} / \mathrm{L}$ (22703) & 0.688 & 0.68 & 1.2 & $<0.004$ & $<0.004$ & -- \\
\hline
\end{tabular}




\section{Surface-Water Quality in the Lycoming Creek Watershed, North-Central Pennsylvania, August 1-3, 2011}

Run. In the sample from Hounds Run, results for aluminum, cobalt, and lead all differed by more than 25 percent. This was partly the result of comparing the rounded values of very small concentrations. The water sample from Hounds Run has a very low concentration of total dissolved solids (between 14 and $17 \mathrm{mg} / \mathrm{L}$ ) causing very small absolute differences in analytical results to be shown as a large percent difference.

Replicate samples were also collected by USGS EWI methods at five sites to compare results from different laboratories (table 8). The comparison of filtered samples analyzed by both labs was not very useful because so many of the results were censored. The comparison of filtered to unfiltered samples for selected cations showed results that were generally in good agreement. One analysis for barium was 51 percent greater in the unfiltered sample analyzed by PaDEP than in the filtered sample analyzed by USGS for Pleasant Stream at Marsh Hill (table 8); however, because barium results agreed closely (within 5 percent) in samples from the other four stream sites, the barium data were not qualified.

\section{Duplicate Samples Collected by EWI and Single- Point Methods}

Duplicate samples were obtained by sampling stream water at the same site using the EWI method and field protocols used by USGS, and the single-point method used by PaDEP. The duplicate samples were sent to both the NWQL and PaDEP laboratories for analysis. The analytical results from NWQL did not indicate any consistent and substantial bias of one collection method over the other (table 9A). Bromide was consistently greater in the single-point samples, but the absolute differences in concentration were slight. Aluminum results were the most variable, with differences as large as 63 percent between the methods; but without consistent bias. The PaDEP laboratory provided fewer results to compare because they were censored at a higher reporting level (table 9B). The greatest difference was 45 percent in one result for barium in Pleasant Stream at Marsh Hill, but the other duplicates for barium were in good agreement. 


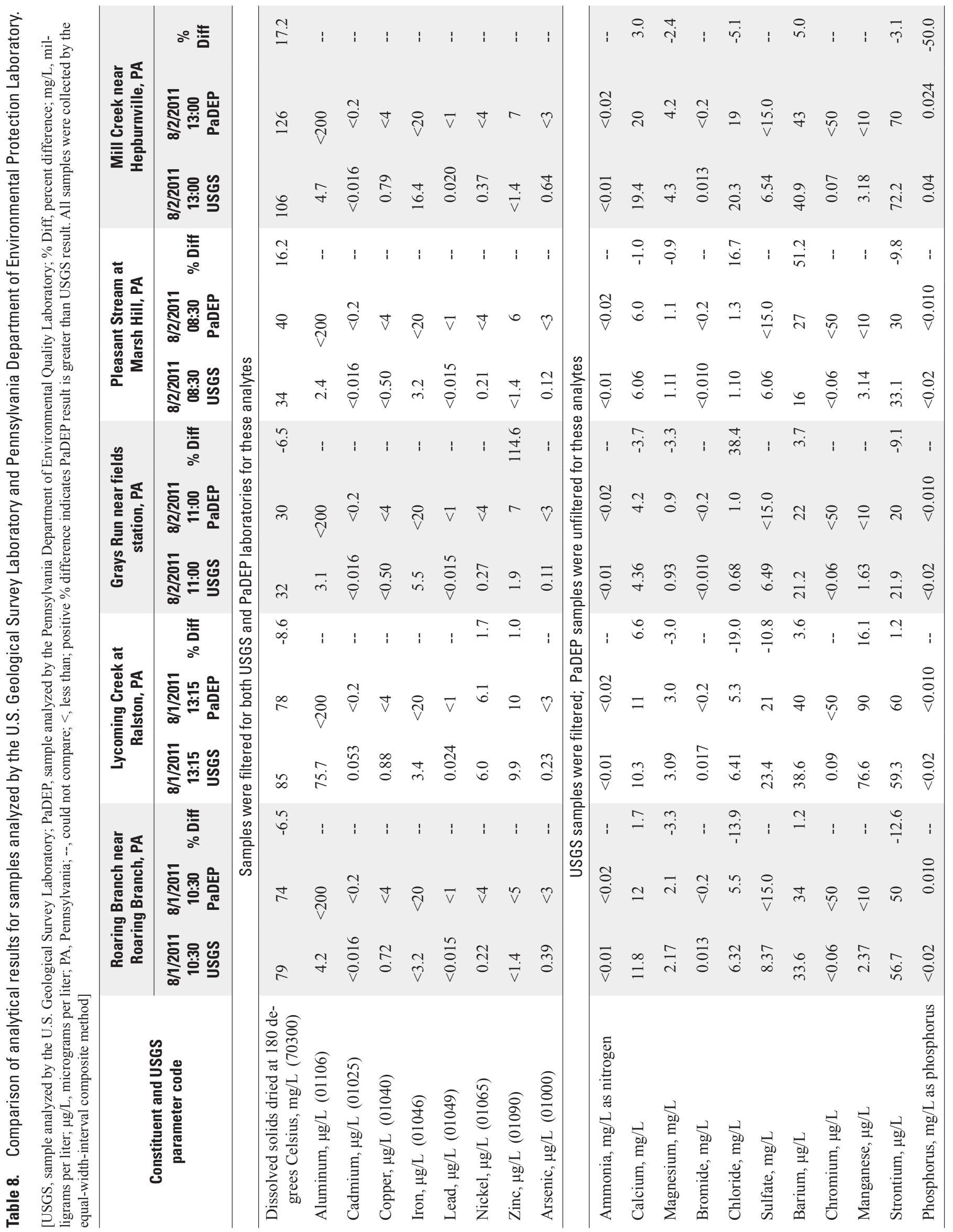




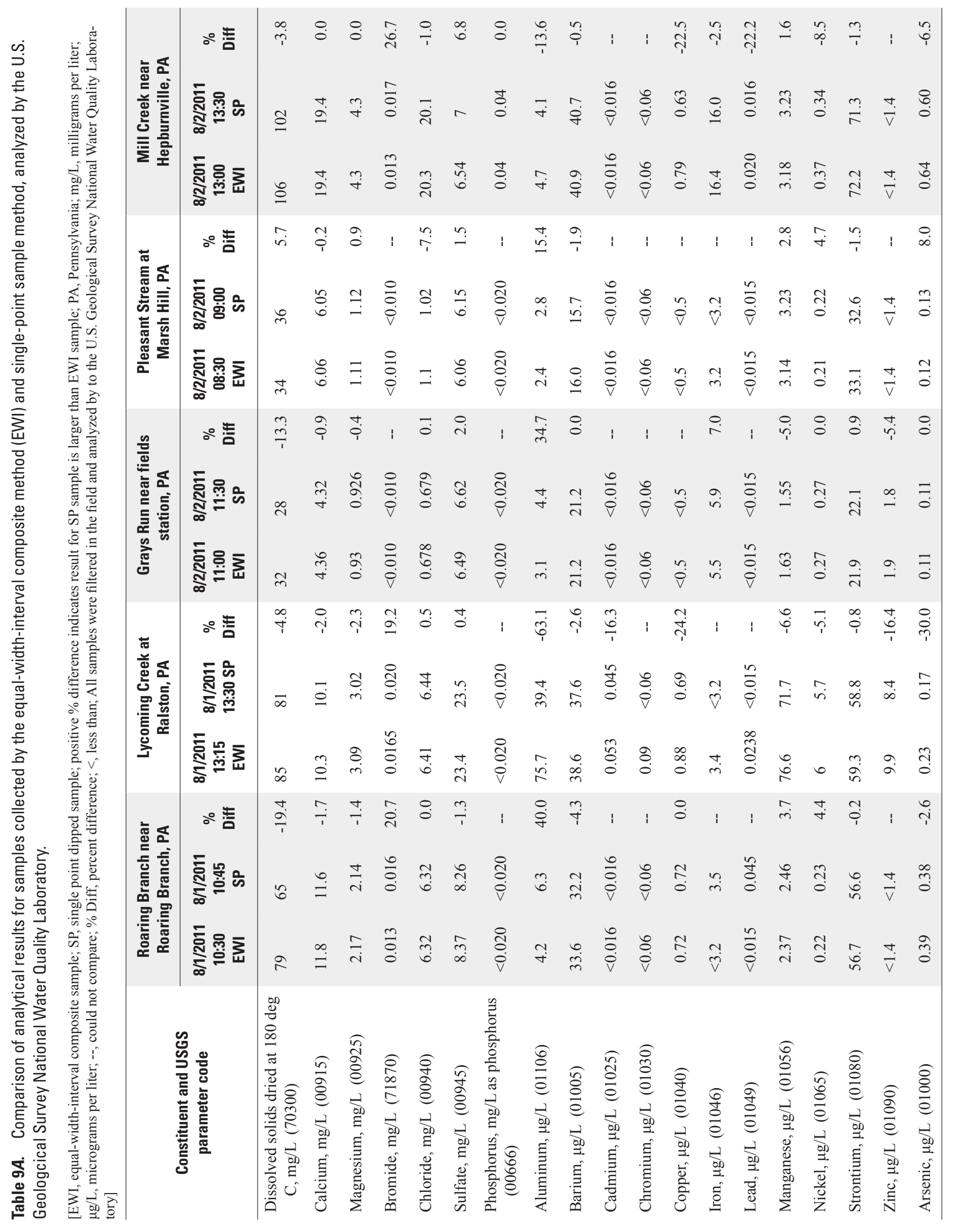




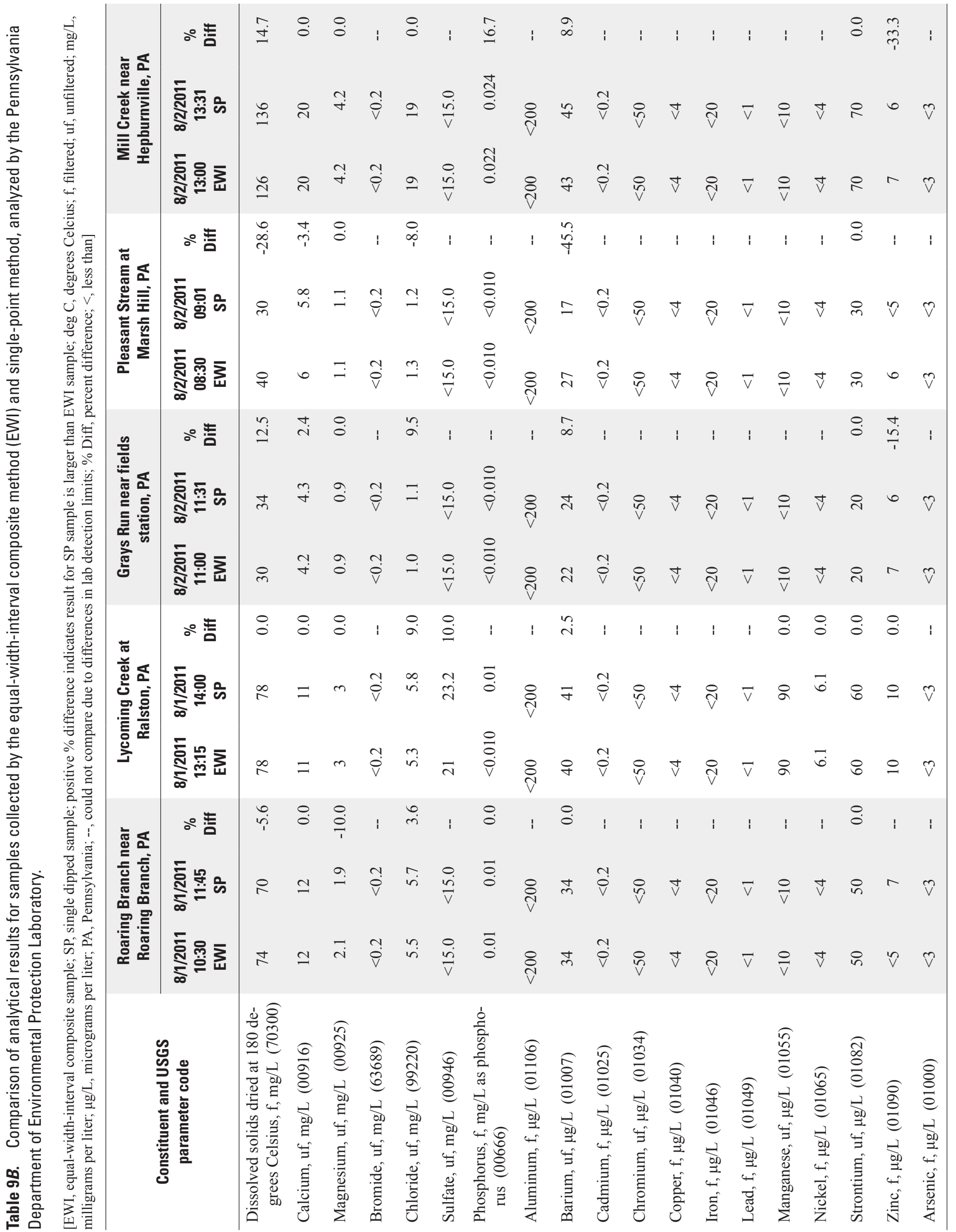




\section{Surface-Water Quality, August 1-3, 2011}

Analytical results for samples of base flow in surface water in the Lycoming Creek watershed sampled at 31 sites during August 1-3, 2011, are given in tables 10-13 (at the back of the report); results are also available online in the USGS NWIS (U.S. Geological Survey, 2017). Those results are summarized and discussed in relation to drinking-water standards, spatial differences, and factors affecting the water quality.

\section{Comparison to Standards and Range of Concentrations}

The results of the water samples are compared to EPA drinking-water standards and other guidelines, and the range of concentrations is given in table 14. Drinking water metrics are used for comparison because the surface water in Lycoming Creek is a source of water that may be captured by production wells as source of public drinking-water supply. The EPA has determined maximum contaminant levels (MCLs) that establish the maximum amount of a given constituent that is allowed in public drinking water (U.S. Environmental Protection Agency, 2016). Secondary maximum contaminant levels (SMCLs) were also established by EPA as guidelines for managing aesthetic considerations, such as taste, color, and odor. For some constituents that do not have an MCL or SMCL, a nonregulatory health-based screening level (HBSL) is listed in table 14. The HBSL is used by the USGS National WaterQuality Assessment Project to show water-quality results in a human-health context (Toccalino and others, 2012).

The concentrations of constituents analyzed for the water sample from the main stem of Lycoming Creek at 3rd Street Bridge (site 31 ) met the respective drinking water standards or screening levels. This sample represents water in Lycoming Creek nearest to the Lycoming Creek well field where water from the creek could be a source of water to the wells. None of the concentrations measured for other samples of surface water from the main stem or tributaries of Lycoming Creek failed to meet any of the MCLs for drinking water; however, concentrations for some constituents at a few sites in the watershed were outside of acceptable SMCL or HBSL ranges (table 15).

\section{Major Constituents and Physical Properties}

Of the major constituents and physical properties analyzed, none failed to meet the MCL and only $\mathrm{pH}$ and sodium were outside of acceptable SMCL or HBSL ranges. The $\mathrm{pH}$ was measured in the field at 20 sites by USGS and was found to be less than the minimum SMCL value of 6.5 at ten of those sites (table 15). Samples from 11 surface-water sites sampled by PaDEP were sent to the PaDEP laboratory for
$\mathrm{pH}$ determination, but comparison of the field and laboratory values showed that the laboratory value was substantially greater than the field value, and was probably not representative of the $\mathrm{pH}$ in the stream. The 10 low values of field $\mathrm{pH}$ are related to past coal mining and acid deposition on watersheds having little natural buffering capacity. The low $\mathrm{pH}$ is not a health concern, but acidic water can mobilize trace metals that do have health-based standards. The sodium concentration was analyzed in samples from 31 surface-water sites. The HBSL for sodium of $20 \mathrm{mg} / \mathrm{L}$ was exceeded at one sample site. The sodium concentration in the sample from Bottle Run (site 30) of $25.8 \mathrm{mg} / \mathrm{L}$ (table 15) failed to meet the HBSL for individuals on sodium-restricted diets.

The range of concentrations found in surface-water samples for the other major constituents that met the drinking water standard or guideline are also listed in table 14 and illustrated with boxplots for some constituents in figure 9. Concentrations of all constituents ranged over at least one order of magnitude, with chloride having the largest range from 0.3 to $45.4 \mathrm{mg} / \mathrm{L}$. The lowest values of acid neutralizing capacity were zero for the acidic waters in Dutchman Run (site 8) and $0.6 \mathrm{mg} / \mathrm{L}$ for Red Run at Ralston (site 7). The dissolved solids concentration was less than the laboratory reporting level of $12 \mathrm{mg} / \mathrm{L}$ for the sample from Wolf Run near Trout Run (site 21), indicating water with remarkably few dissolved solids.

\section{Trace Constituents}

The concentrations of trace constituents ranged widely in the surface-water samples from Lycoming Creek watershed. Of the 22 trace metals included in the analysis; only silver was a nondetect in all of the samples. The trace constituents detected at every site in the watershed were aluminum, arsenic, barium, boron, lithium, manganese, nickel, selenium, and strontium. Other constituents that were found in at least half of the sites include antimony, beryllium, bromide, cobalt, fluoride, iron, lead, molybdenum, and zinc. Other metals that were detected at less than half the sites include cadmium, chromium, and copper. The range in concentration of trace constituents in samples from Lycoming Creek watershed was generally greater than for the major constituents. Concentrations of aluminum, cobalt, and manganese ranged over at least three orders of magnitude in samples, and concentrations of beryllium, iron, lead, lithium, nickel, and zinc ranged over at least two orders of magnitude.

Of the 22 trace constituents analyzed, only concentrations of aluminum, manganese, and iron were outside acceptable SMCL ranges in one or more surface-water samples (table 15). Guidelines for these constituents are given because concentrations not meeting the standard can impart an objectionable water color, staining, or metallic taste. The SMCL of $50 \mu \mathrm{g} / \mathrm{L}$ for both aluminum and manganese was exceeded at sites on Dutchman Run (site 8), Red Run near Ralston (site 7), and Lycoming Creek at Ralston (site 9). The SMCL was also exceeded for aluminum in Frozen Run (site 13) and 
Table 14. Minimum, median, and maximum values for major constituents, trace constituents, nutrients, and radiochemicals for surface-water samples from the Lycoming Creek watershed, north-central Pennsylvania, August 1-3, 2011.

$\left[\mathrm{mg} / \mathrm{L}\right.$, milligrams per liter; $\mu \mathrm{g} / \mathrm{L}$, micrograms per liter; $\mathrm{mg} / \mathrm{L}$ as $\mathrm{CaCO}_{3}$, milligrams per liter as calcium carbonate; ${ }^{\circ} \mathrm{C}$, degrees Celsius; $\mu \mathrm{S} / \mathrm{cm}$, microsiemens per centimeter at 25 degrees Celsius; $\mathrm{SiO}_{2}$, silica; --, no data or not applicable; MCL, maximum contaminant level; HBSL, health based screening level; TT, treatment technology; SMCL, secondary maximum contaminant level]

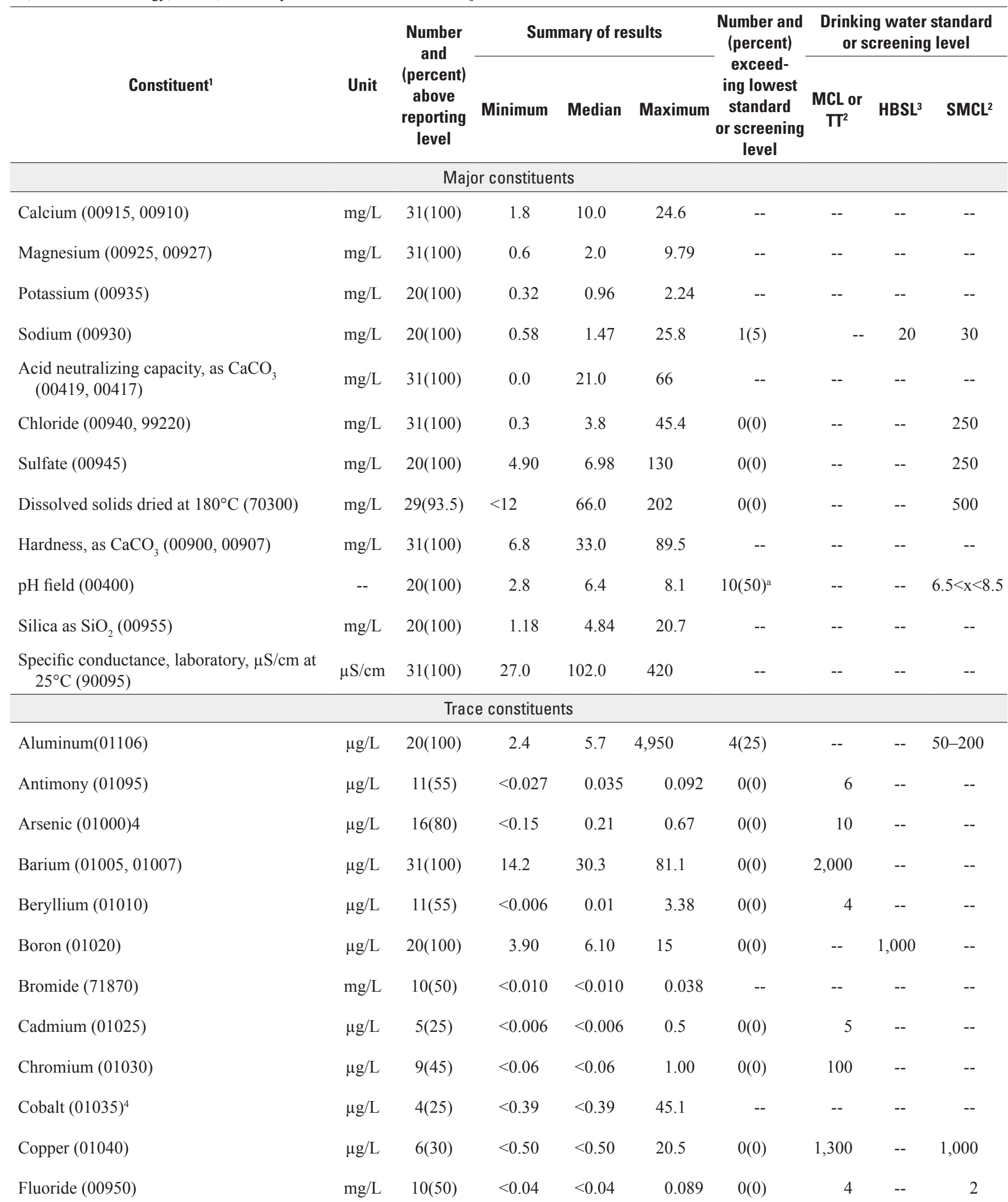


Table 14. Minimum, median, and maximum values for major constituents, trace constituents, nutrients, and radiochemicals for surface-water samples from the Lycoming Creek watershed, north-central Pennsylvania, August 1-3, 2011._Continued

$\left[\mathrm{mg} / \mathrm{L}\right.$, milligrams per liter; $\mu \mathrm{g} / \mathrm{L}$, micrograms per liter; $\mathrm{mg} / \mathrm{L}$ as $\mathrm{CaCO}_{3}$, milligrams per liter as calcium carbonate; ${ }^{\circ} \mathrm{C}$, degrees Celsius; $\mu \mathrm{S} / \mathrm{cm}$, microsiemens per centimeter at 25 degrees Celsius; $\mathrm{SiO}_{2}$, silica; --, no data or not applicable; MCL, maximum contaminant level; HBSL, health based screening level; TT, treatment technology; SMCL, secondary maximum contaminant level]

\begin{tabular}{|c|c|c|c|c|c|c|c|c|c|}
\hline Constituent ${ }^{1}$ & Unit & $\begin{array}{l}\text { Number } \\
\text { and } \\
\text { (percent) } \\
\text { above } \\
\text { reporting } \\
\text { level }\end{array}$ & \multicolumn{3}{|c|}{ Summary of results } & $\begin{array}{l}\text { Number and } \\
\text { (percent) } \\
\text { exceed- } \\
\text { ing lowest } \\
\text { standard } \\
\text { or screening } \\
\text { level }\end{array}$ & \multicolumn{3}{|c|}{$\begin{array}{l}\text { Drinking water standard } \\
\text { or screening level }\end{array}$} \\
\hline Lead (01049) & $\mu \mathrm{g} / \mathrm{L}$ & $12(60)$ & $<0.015$ & 0.02 & 4.06 & $0(0)$ & 15 & -- & -- \\
\hline Lithium (01130) & $\mu \mathrm{g} / \mathrm{L}$ & $20(100)$ & 0.26 & 0.57 & 49.2 & -- & -- & -- & -- \\
\hline Manganese $(01056)^{4}$ & $\mu \mathrm{g} / \mathrm{L}$ & $17(85)$ & $<0.85$ & 3.16 & 1,770 & $4(20)$ & -- & 300 & 50 \\
\hline Selenium (01145) & $\mu \mathrm{g} / \mathrm{L}$ & $20(100)$ & 0.04 & 0.05 & 0.83 & $0(0)$ & 50 & -- & -- \\
\hline Silver (01075) & $\mu \mathrm{g} / \mathrm{L}$ & $0(0)$ & $<0.005$ & $<0.005$ & $<0.005$ & $0(0)$ & -- & -- & 100 \\
\hline Strontium $(01080,01082)$ & $\mu \mathrm{g} / \mathrm{L}$ & $31(100)$ & 17.0 & 50.0 & 120 & $0(0)$ & -- & 4,000 & -- \\
\hline Zinc (01090) & $\mu \mathrm{g} / \mathrm{L}$ & $17(54.8)$ & $<1.4$ & 1.9 & 190 & $0(0)$ & -- & -- & 5,000 \\
\hline \multicolumn{10}{|c|}{ Nutrients } \\
\hline Ammonia as nitrogen $(00608,00610)$ & $\mathrm{mg} / \mathrm{L}$ & $3(9.7)$ & $<0.01$ & $<0.01$ & 0.0600 & $0(0)$ & -- & 30 & -- \\
\hline Phosphorus as phosphorus $(00666,00665)$ & $\mathrm{mg} / \mathrm{L}$ & $7(22.6)$ & $<0.02$ & $<0.02$ & 0.036 & -- & -- & -- & -- \\
\hline \multicolumn{10}{|c|}{ Radiochemicals } \\
\hline Uranium (22703) & $\mu \mathrm{g} / \mathrm{L}$ & $17(85)$ & $<0.004$ & 0.01 & 0.688 & $0(0)$ & 30 & -- & -- \\
\hline $\begin{array}{l}\text { Gross alpha radioactivity, } 30 \text { day count, } \\
\text { Th-230 curve (62639) }\end{array}$ & $\mathrm{pCi} / \mathrm{L}$ & $2(10)$ & $<0.20$ & $<0.20$ & 1.17 & $0(0)$ & 15 & -- & -- \\
\hline $\begin{array}{l}\text { Gross beta radioactivity, } 30 \text { day count, } \\
\text { Cs-137 curve }(62645)\end{array}$ & $\mathrm{pCi} / \mathrm{L}$ & $8(40)$ & $<0.70$ & $<0.70$ & 1.76 & -- & -- & -- & -- \\
\hline
\end{tabular}

${ }^{1}$ Constituents are listed with the parameter code. Where two codes are listed, the first corresponds to the U.S. Geological Survey analysis for a filtered sample followed by the Pennsylvania Department of Environmental Protection analyis of the unfiltered sample. The number of environmental samples listed is the sum of the. The number of environmental samples listed is the sum of filtered and unfiltered samples.

${ }^{2}$ U.S. Environmental Protection Agency (2016).

${ }^{3}$ Toccalino and others (2012).

${ }^{4}$ Reporting level increased to five-times the concentration detected in the blank water sample for this constituent.

${ }^{\mathrm{a}} \mathrm{pH}$ was less than 6.5 ; no values were greater than 8.5 . 
Table 15. Surface-water sampling sites where a secondary maximum contaminant level (SMCL) or health based screening level (HBSL) for at least one constituent was not achieved in the Lycoming Creek watershed, north-central Pennsylvania, August 1-3, 2011.

$[\mathrm{mg} / \mathrm{L}$, milligrams per liter; $\mu \mathrm{g} / \mathrm{L}$, micrograms per liter; $<$, less than; HBSL, health based screening level; SMCL, secondary maximum contaminant level; PA, Pennsylvania; N, north; --, results were within acceptable rage for the constituent]

\begin{tabular}{|c|c|c|c|c|c|}
\hline \multirow{3}{*}{ Site name } & \multicolumn{5}{|c|}{$\begin{array}{l}\text { Analytical results for constitutents that did not meet } \\
\text { the SMCL or HBSL for drinking water }\end{array}$} \\
\hline & $\underset{\text { (units) }}{\mathrm{pH}}$ & $\begin{array}{c}\text { Aluminum } \\
(\mu \mathrm{g} / \mathrm{L})\end{array}$ & $\begin{array}{l}\text { Iron } \\
(\mu \mathrm{g} / \mathrm{L})\end{array}$ & Manganese $(\mu \mathrm{g} / \mathrm{L})$ & $\begin{array}{l}\text { Sodium } \\
\text { (mg/L) }\end{array}$ \\
\hline & SMCL $6.5<\mathrm{pH}<8.5$ & SMCL is 50 & SMCL is 300 & SMCL is 50 & HBSL is 20 \\
\hline Lycoming Creek near Dogtown, PA & 5.4 & -- & -- & -- & -- \\
\hline Salt Spring Run near South Union, PA & 5.6 & -- & -- & -- & -- \\
\hline Red Run at Ralston, PA & 3.9 & 606 & -- & 641 & -- \\
\hline Dutchman Run near Ralston, PA & 2.8 & 4,950 & 498 & 1,770 & -- \\
\hline Hounds Run at McIntyre Township, PA & 5.0 & -- & -- & -- & -- \\
\hline Frozen Run near Ralston, PA & 4.9 & 59.1 & -- & -- & -- \\
\hline Grays Run near Fields Station, PA & 6.3 & -- & -- & -- & -- \\
\hline Trout Run at Route $15 \mathrm{~N}$ at Lewis Township, PA & 4.7 & -- & -- & -- & -- \\
\hline Wolf Run near Trout Run, PA & 5.2 & -- & -- & -- & -- \\
\hline
\end{tabular}

for manganese in Bottle Run (site 30). The SMCL for iron of $300 \mu \mathrm{g} / \mathrm{L}$ was exceeded at Dutchman Run. The relatively elevated concentrations of these trace metals are related to low $\mathrm{pH}$ at these sites, except for the sample collected in Bottle Run, which is the most urbanized tributary basin in the Lycoming Creek watershed.

\section{Nutrients}

Surface-water samples from the Lycoming Creek watershed were analyzed for total nitrogen, organic nitrogen, nitrate, nitrite, and ammonia, as well as phosphorus and orthophosphate. None of the species of nitrogen or phosphorus were found in concentrations failing to meet a drinking water standard or guideline (table 14). Elevated concentrations of nitrogen compounds can pose a hazard for human consumption, so an MCL has been established by EPA for nitrate $(10 \mathrm{mg} / \mathrm{L})$ and nitrite $(1 \mathrm{mg} / \mathrm{L})$ and a HBSL is available for ammonia $(30 \mathrm{mg} / \mathrm{L})$. Phosphate is not associated with humanhealth problems, but concentrations greater than $1 \mathrm{mg} / \mathrm{L}$ may affect coagulation processes at water-treatment facilities. Nationally, nitrogen and phosphorus compounds occur naturally at concentrations typically less than about $0.58 \mathrm{mg} / \mathrm{L}$ for nitrate and 0.034 for total phosphorus (Dubrovsky and others, 2010, p. 52). Higher concentrations may indicate contamination from a number of potential sources, such as domestic and municipal wastewater, fertilizer, animal manure, and storm-water runoff.

Nitrate was detected at levels above the laboratory reporting level in all 31 samples. The highest measured concentration of nitrate of $1.55 \mathrm{mg} / \mathrm{L}$ (as nitrogen) from the sample in Mill Creek near Hepburnville (site 27) is less than 20 percent of the MCL value. Concentrations of ammonia (as nitrogen) were detected in only 3 of 31 samples, with a maximum value of $0.06 \mathrm{mg} / \mathrm{L}$ (table 14). Ammonium and nitrite were found in low concentrations because they are reduced forms of nitrogen that are typically more stable in low-oxygen environments, while nitrate is oxidized and therefore more stable in these stream settings.

Orthophosphate concentrations above the reporting level of $0.004 \mathrm{mg} / \mathrm{L}$ were found in 10 of the 20 USGS sampling 


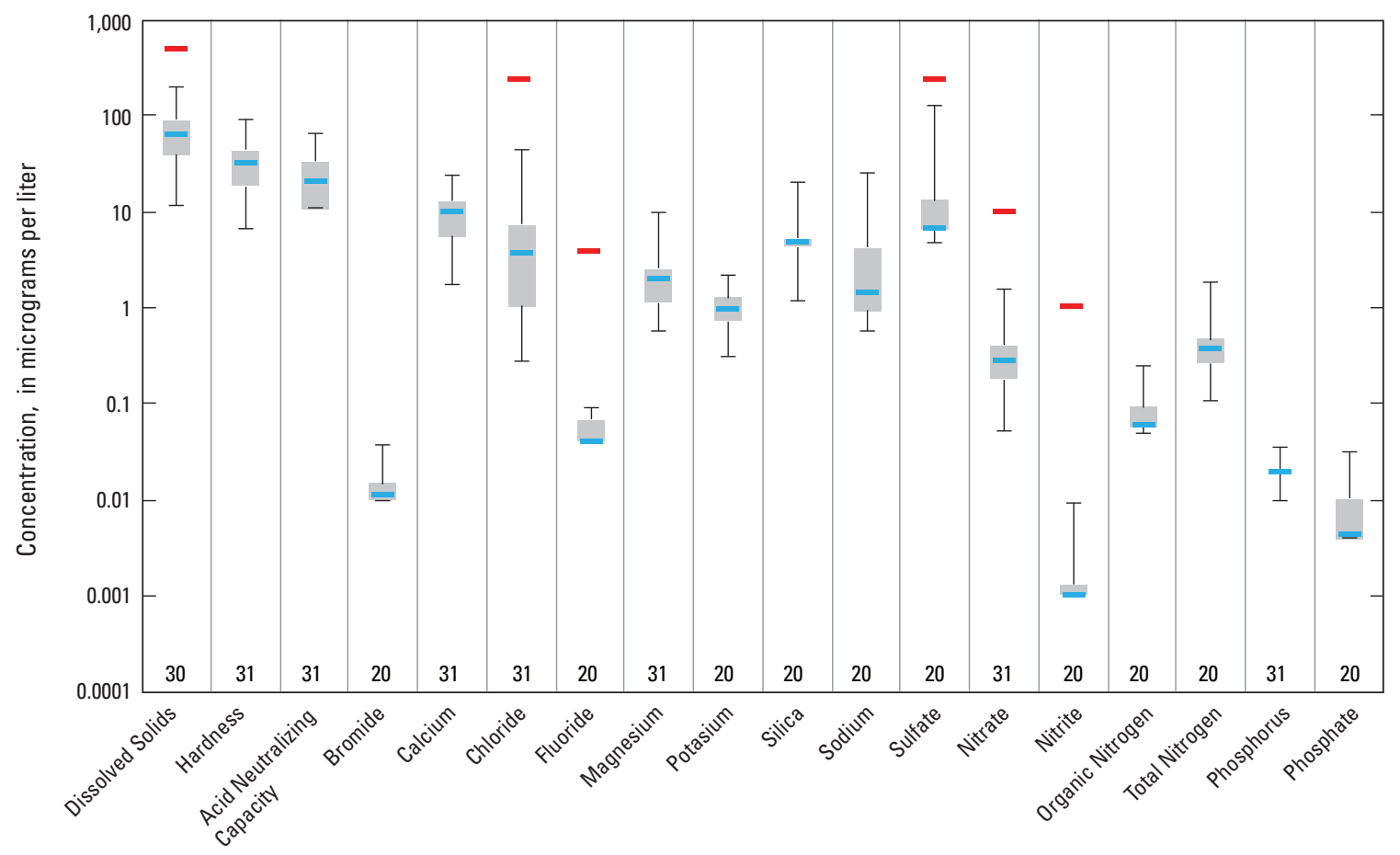

EXPLANATION

Maximum contaminant level (MCL)

$\left[\begin{array}{l}\text { Maximum } \\ \text { 75th percentile }\end{array}\right.$

Median

25th percentile

Minimum

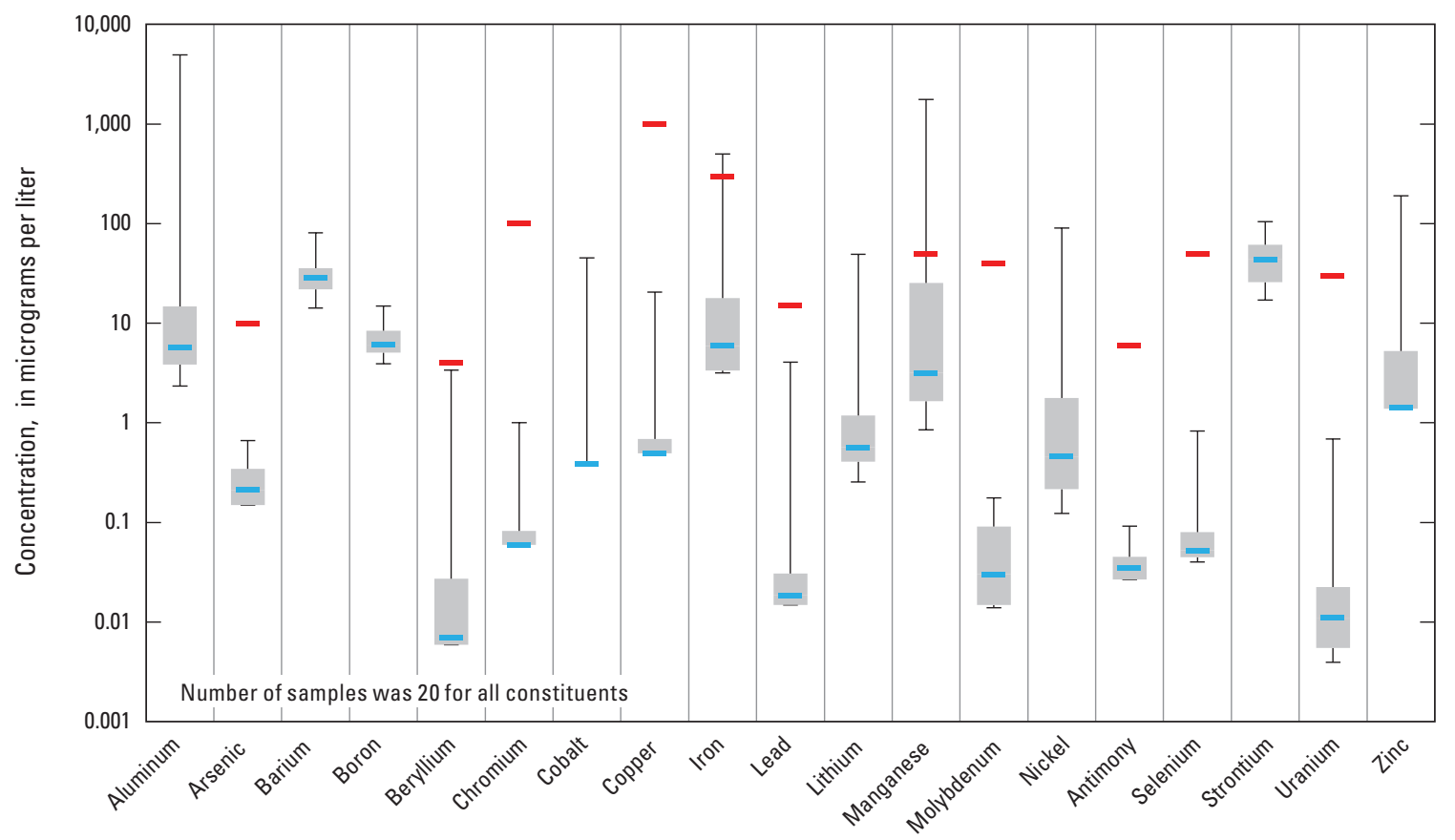

30 Number of samples

Figure 9. Comparison of concentrations for selected water-quality constituents in surface-water samples in the Lycoming Creek watershed, north-central Pennsylvania, August 1-3, 2011. 
locations in the Lycoming Creek watershed. The reported concentrations were very low, ranging from 0.005 to $0.032 \mathrm{mg} / \mathrm{L}$ (as phosphorus), with a median value of $0.010 \mathrm{mg} / \mathrm{L}$. Orthophosphate concentrations equal to or less than about $0.01 \mathrm{mg} / \mathrm{L}$ are within the range of national background levels (Dubrovsky and others, 2010, p. 52).

\section{Radiochemicals}

Radionuclides that are naturally present in soils and rocks may be dissolved and enter into surface water. Each radionuclide will emit alpha particles or beta particles while it undergoes radioactive decay. Surface-water samples from 20 sites were analyzed at the laboratory for gross alpha and gross beta radiation and total uranium. The highest gross alpha activity was $2.1 \mathrm{pCi} / \mathrm{L}$, well within the acceptable range below the $\mathrm{MCL}$ of $15 \mathrm{pCi} / \mathrm{L}$ (table 11 at the end of the report). Uranium was present in 17 of the 20 samples and had a maximum value of $0.688 \mu \mathrm{g} / \mathrm{L}$ at Dutchman Run near Ralston (site 8), much less than the MCL of $30 \mu \mathrm{g} / \mathrm{L}$ (table 14).

\section{Spatial Differences and Factors Affecting Water Quality}

The quality of surface water is not uniform throughout the Lycoming Creek watershed. The Lycoming Creek watershed was divided into three parts - upper, middle, and lowerbased on physiographic sections, which provides a useful way to discuss the major spatial differences in base-flow quality. The upper basin is mostly within the Glaciated Low Plateau Section of the Appalachian Plateaus Physiographic Province; the middle basin is within the Deep Valleys and Glaciated High Plateau Sections of the Appalachian Plateaus Physiographic Province; and the lower part is in the Susquehanna Lowland Section of the Valley and Ridge Physiographic Province (fig. 2). Many of the major differences in water quality among the tributary streams and along the main stem of Lycoming Creek can be attributed to differences in the geology and land use of the upper, middle, and lower parts of the watershed.

The geologic formations and land uses for sampling sites in the upper, middle, and lower parts of Lycoming Creek watershed are generalized in figure 10. The figure shows that bedrock geology and land use are related. The upper and lower parts of the Lycoming Creek watershed are partly underlain with siltstones and shales of the Lock Haven Formation and older formations and a substantial amount of land is used for agriculture, with some suburban/commercial development. The middle part of the watershed is underlain by the Huntley Mountain Formation and younger formations, which consist predominantly of resistant sandstones that create steep topography that is not well suited for agriculture or development. Land use in the middle part is also constrained because about 40 percent of the area is state forest or state game land, where access and use is controlled.

\section{Water Types}

The relative concentrations of major ions in the upper, middle, and lower parts of Lycoming Creek watershed are illustrated by the use of stiff diagrams and specific-conductance values for the 20 stream sites sampled by USGS (fig. 11). The pattern of the Stiff diagram is determined by the relative proportions of cations and anions, expressed in equivalent weight units, and the size is determined by the absolute concentrations. The thickness of the stream in figure 11 also illustrates the approximate relative magnitude of stream discharge measured at the time of sample collection.

Figure 11 shows that streams in the upper part of Lycoming Creek watershed have calcium-bicarbonate-type waters with specific conductance values from 89 to $128 \mu \mathrm{S} / \mathrm{cm}$ at $25^{\circ} \mathrm{C}$. Streams in the middle part of the watershed are characterized, in general, by waters with much lower dissolved solids (specific conductance generally less than $50 \mu \mathrm{S} / \mathrm{cm}$ ) and a greater percentage of sulfate relative to other anions. Two streams in the middle part (Dutchman Run and Red Run) have specific conductance values greater than $100 \mu \mathrm{S} / \mathrm{cm}$ and sulfate is the predominant anion, probably because of past coal mining in these watersheds. Samples from streams in the lower part of the watershed show an increase in chloride concentration relative to the other anions when compared to samples from the upper and middle parts of the Lycoming Creek watershed.

\section{Concentration Maps}

Maps showing the spatial variability in concentrations for selected constituents are shown in figures $12 \mathrm{~A}-\mathrm{J}$. The constituents selected for mapping were those that were analyzed by USGS and PaDEP at all 31 surface-water sites and had results greater than the laboratory reporting level (the larger level if the reporting levels differed) at six or more sites. The constituents mapped are dissolved solids, hardness, acid neutralizing capacity, chloride, barium, strontium, iron, zinc, and nitrate. A map for $\mathrm{pH}$ determined in the field is also presented for the 20 sites sampled by USGS.

\section{Dissolved Solids}

Concentrations of dissolved solids (analyzed by drying at 180 degrees Celsius) ranged from less than 12 to $202 \mathrm{mg} / \mathrm{L}$ (fig. 12A). In the upper part of the watershed, concentrations were fairly similar, mostly within 44 to $79 \mathrm{mg} / \mathrm{L}$. Samples from streams in the middle part of the watershed showed the greatest differences, from the nearly pristine water (less than $12 \mathrm{mg} / \mathrm{L}$ ) in Wolf Run (site 21) to the coal-mining affected water (191 mg/L) in Dutchman Run (site 8), indicating that differences in land use in this part of the basin can have a large influence on dissolved-solids concentrations. In general, however, most of the streams in the middle part of the watershed (12 of 18 sites) had water with low dissolved solids concentrations-less than $44 \mathrm{mg} / \mathrm{L}$. The highest concentration 

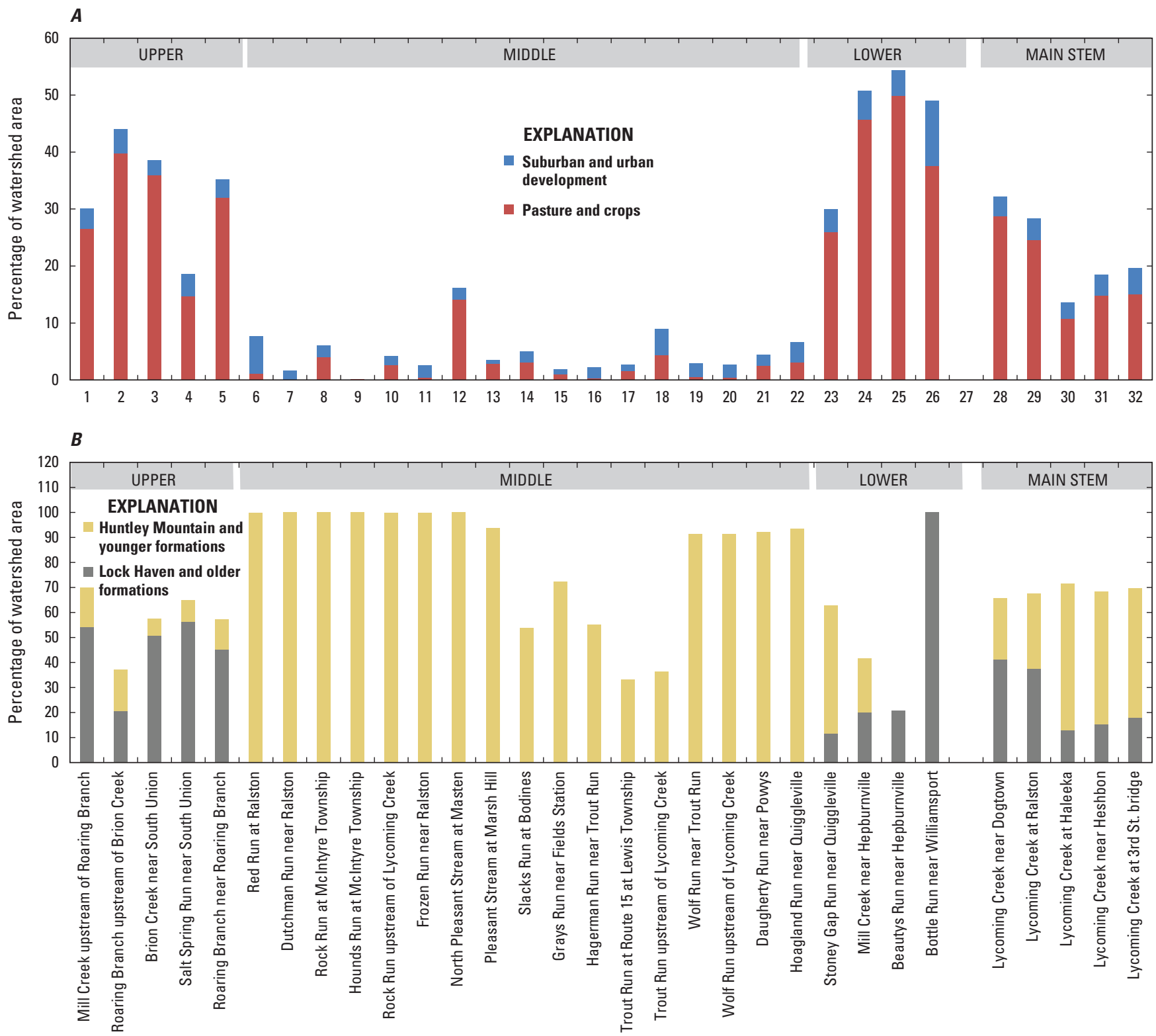

Figure 10. Percentage of the watershed area of selected $(A)$ land uses and $(B)$ geologic formations for tributary streams and sampling sites on the main stem of Lycoming Creek, in downstream order (left to right) from the upper, middle, and lower sections of Lycoming Creek watershed.

of $202 \mathrm{mg} / \mathrm{L}$ was from Bottle Run (site 30), which flows through an area of suburban/commercial development in the lower part of the study area near Williamsport. On the main stem of Lycoming Creek, concentrations of dissolved solids in five samples ranged from $66-96 \mathrm{mg} / \mathrm{L}$. Concentrations were greatest at the most upstream site on Lycoming Creek near Dogtown (site 1) and lowest at the site near Heshbon Park (site 29). The low value at Heshbon Park is difficult to explain. Based on dilution from tributary inflows with low dissolvedsolids concentrations from the middle part of the watershed, the main-stem site at Haleeka (site 24) would be expected to have the lowest dissolved-solids concentration. It is possible that this sample, the last one collected on August 3, was affected by the slight increase in stream discharge during the previous day (fig. 7).

\section{Hardness}

Concentrations of hardness ranged from 6.8 to $89.5 \mathrm{mg} / \mathrm{L}$ as calcium carbonate (fig. 12B). Water from all but four sites can be characterized as "soft" with hardness concentrations of less than $60 \mathrm{mg} / \mathrm{L}$ (Hem, 1985, p 159). Water sampled from the other four sites - Bottle Run (site 30), Beautys Run (site 28), Mill Creek near Hepburnville (site 27), and Dutchman Run (site 8) - is within the "moderately hard" category 


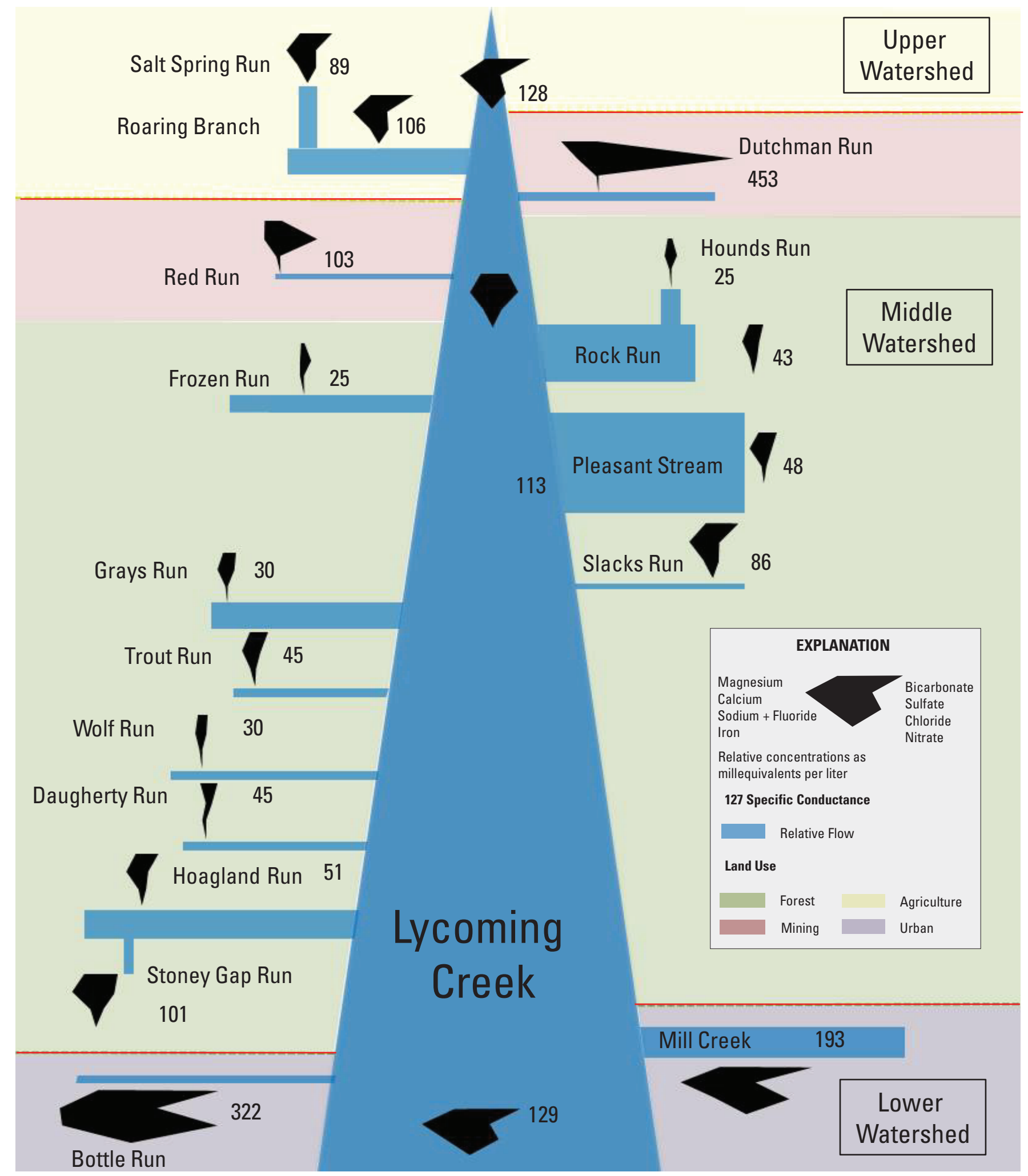

Figure 11. Stiff diagrams and specific-conductance values for 20 water samples collected by the U.S. Geological Survey in the Lycoming Creek watershed, August 1-3, 2011. 


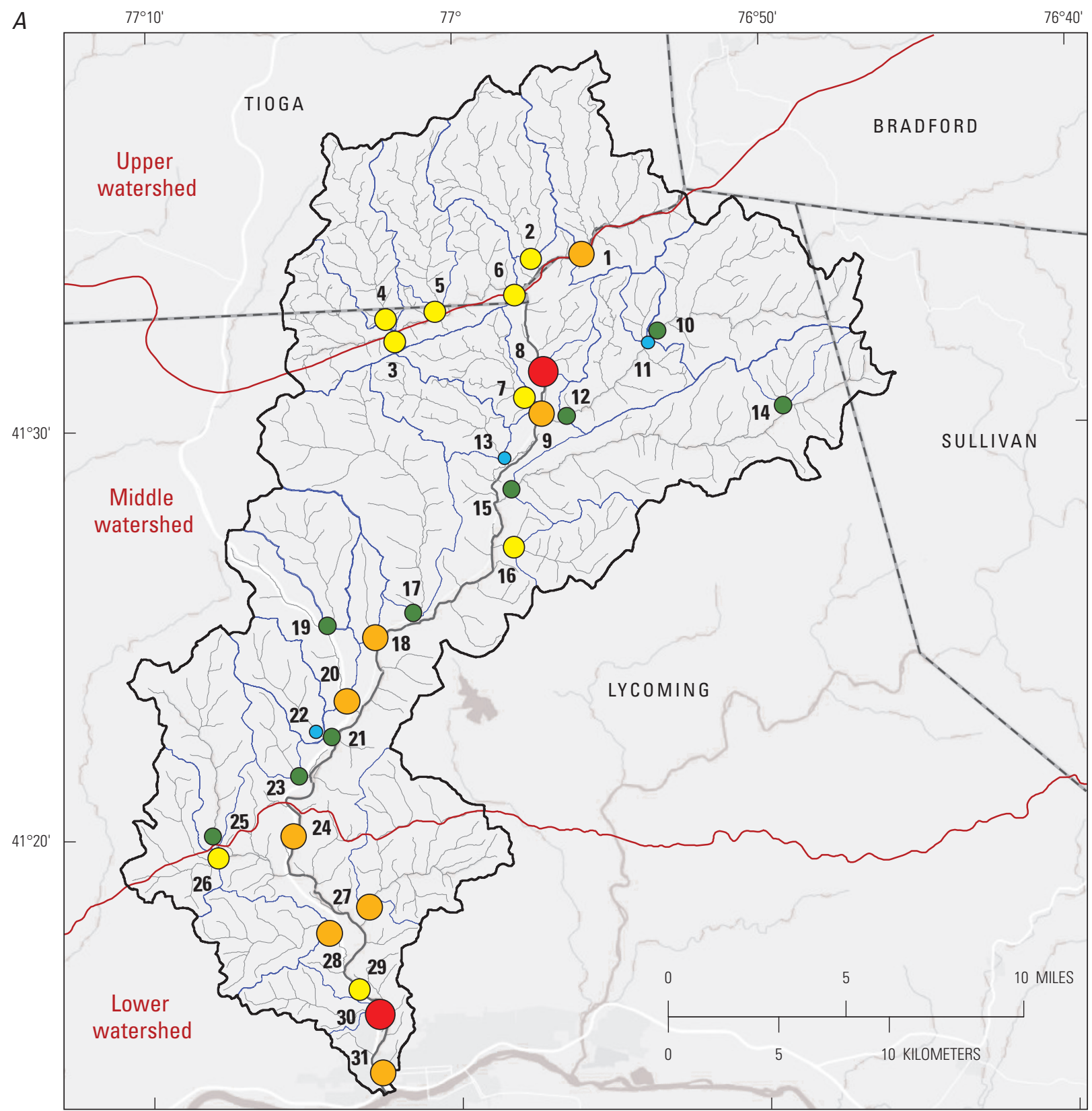

Base map image is the intellectual property of Esri and is used herein under license. Copyright $\odot 2014$ Esri and its licensors. All rights reserved

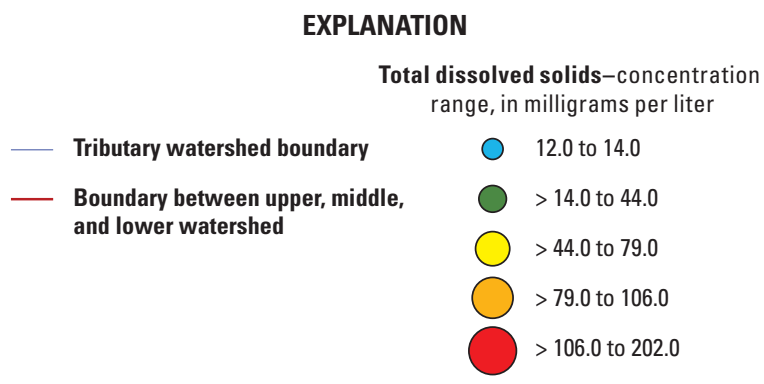

Figure 12A. Spatial variability for $(A)$ total dissolved solids, $(B)$ hardness, $(C)$ acid neutralizing capacity, $(D)$ chloride, $(E)$ barium, $(F)$ strontium, (G) iron, (H) zinc, (/) nitrate, and (J) field pH in the Lycoming Creek, Watershed, August 1-3, 2011. (Sites 1, 9, 24, 29, and 31 are on the main stem of Lycoming Creek) 


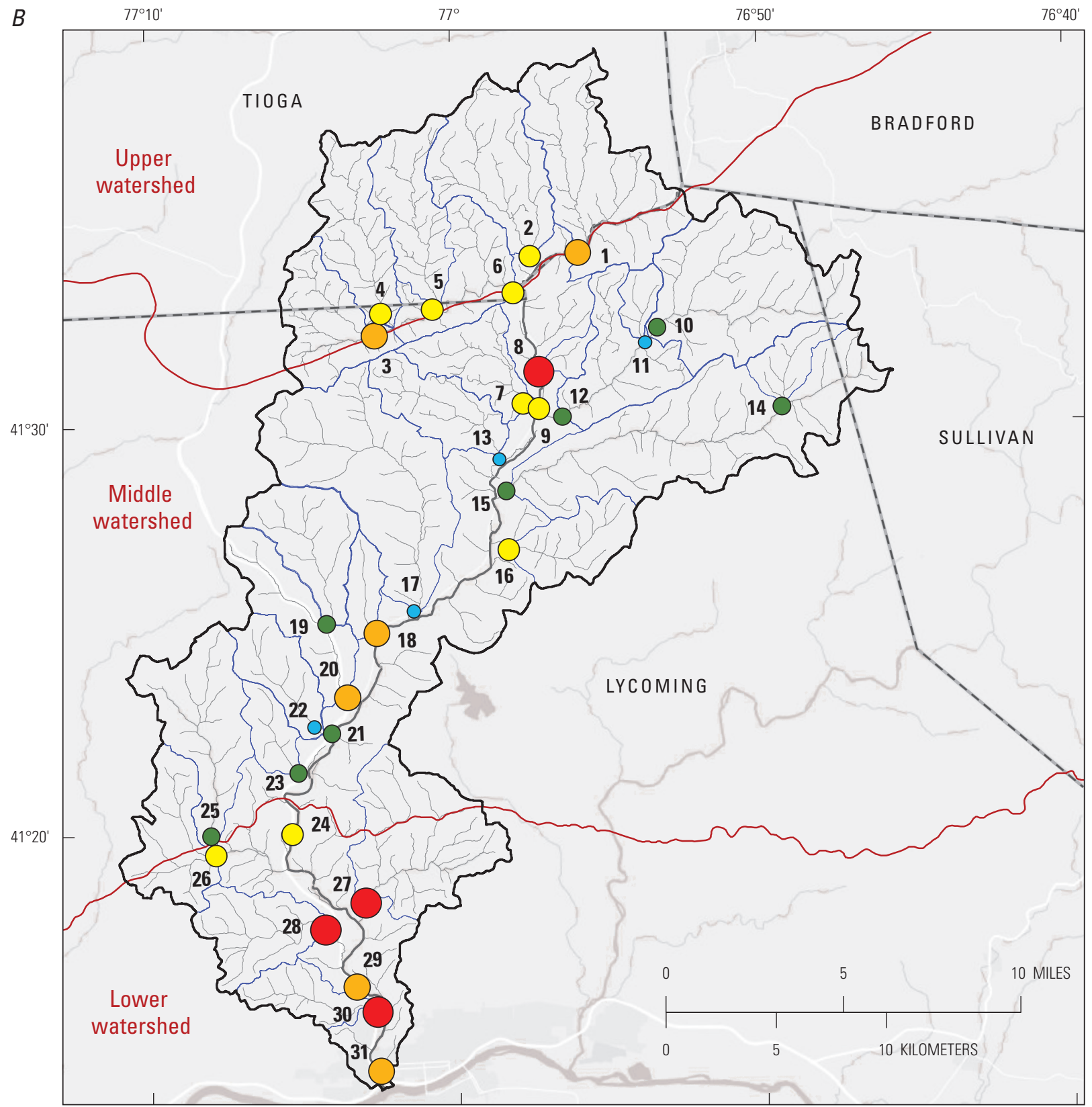

Base map image is the intellectual property of Esri and is used herein under license. Copyright (c) 2014 Esri and its licensors. All rights reserved

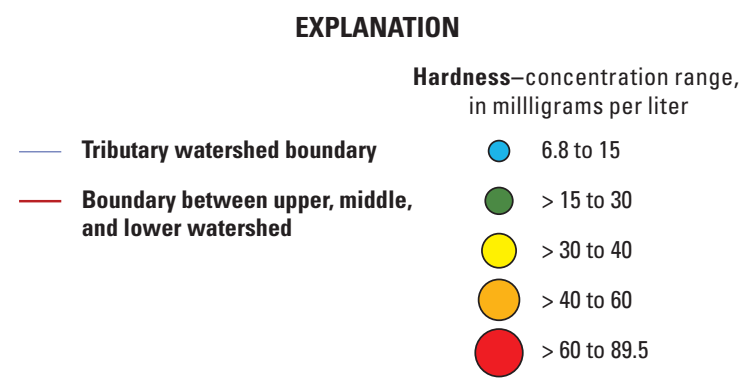

Figure 12B. Spatial variability for $(A)$ total dissolved solids, $(B)$ hardness, $(C)$ acid neutralizing capacity, $(D)$ chloride, $(E)$ barium, $(F)$ strontium, $(G)$ iron, $(H)$ zinc, ( $/$ ) nitrate, and (J) field pH in the Lycoming Creek, Watershed, August 1-3, 2011. (Sites 1, 9, 24, 29, and 31 are on the main stem of Lycoming Creek)—Contuined 


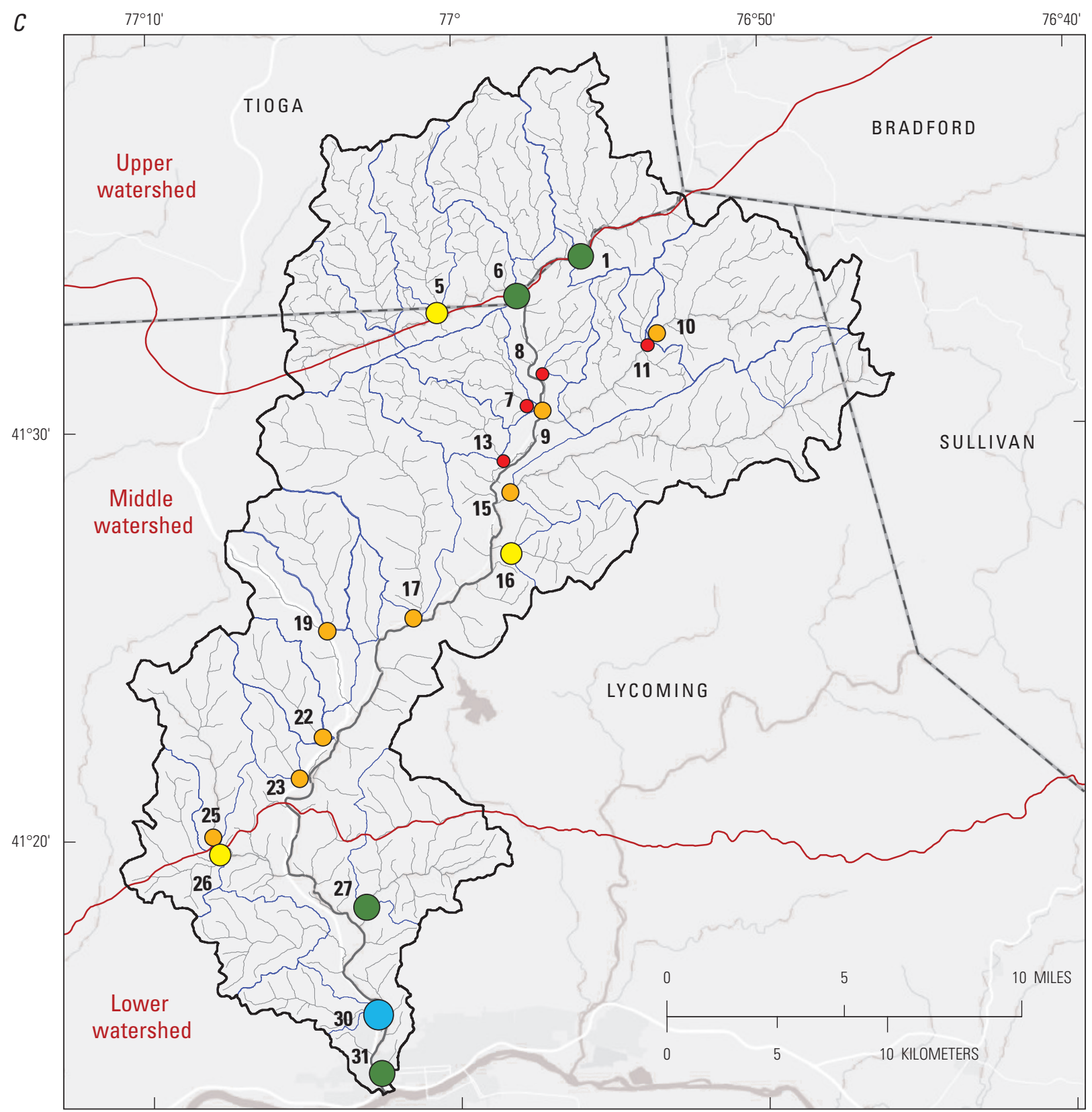

Base map image is the intellectual property of Esri and is used herein under license. Copyright (c) 2014 Esri and its licensors. All rights reserved

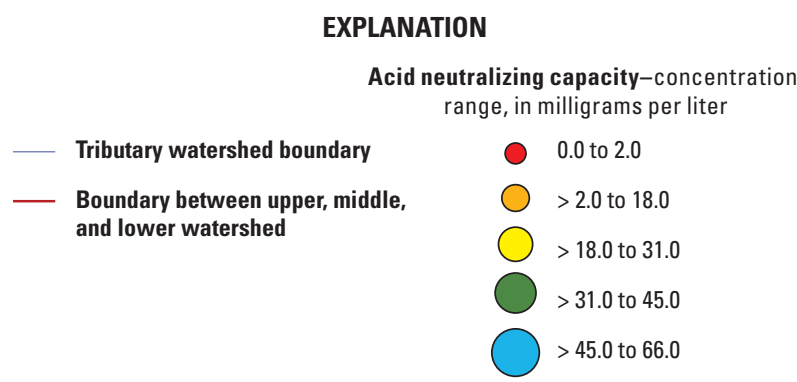

Figure 12C. Spatial variability for $(A)$ total dissolved solids, $(B)$ hardness, $(C)$ acid neutralizing capacity, $(D)$ chloride, $(E)$ barium, $(F)$ strontium, $(G)$ iron, $(H)$ zinc, (/) nitrate, and (J) field pH in the Lycoming Creek, Watershed, August 1-3, 2011. (Sites 1, 9, 24, 29, and 31 are on the main stem of Lycoming Creek)—Contuined 


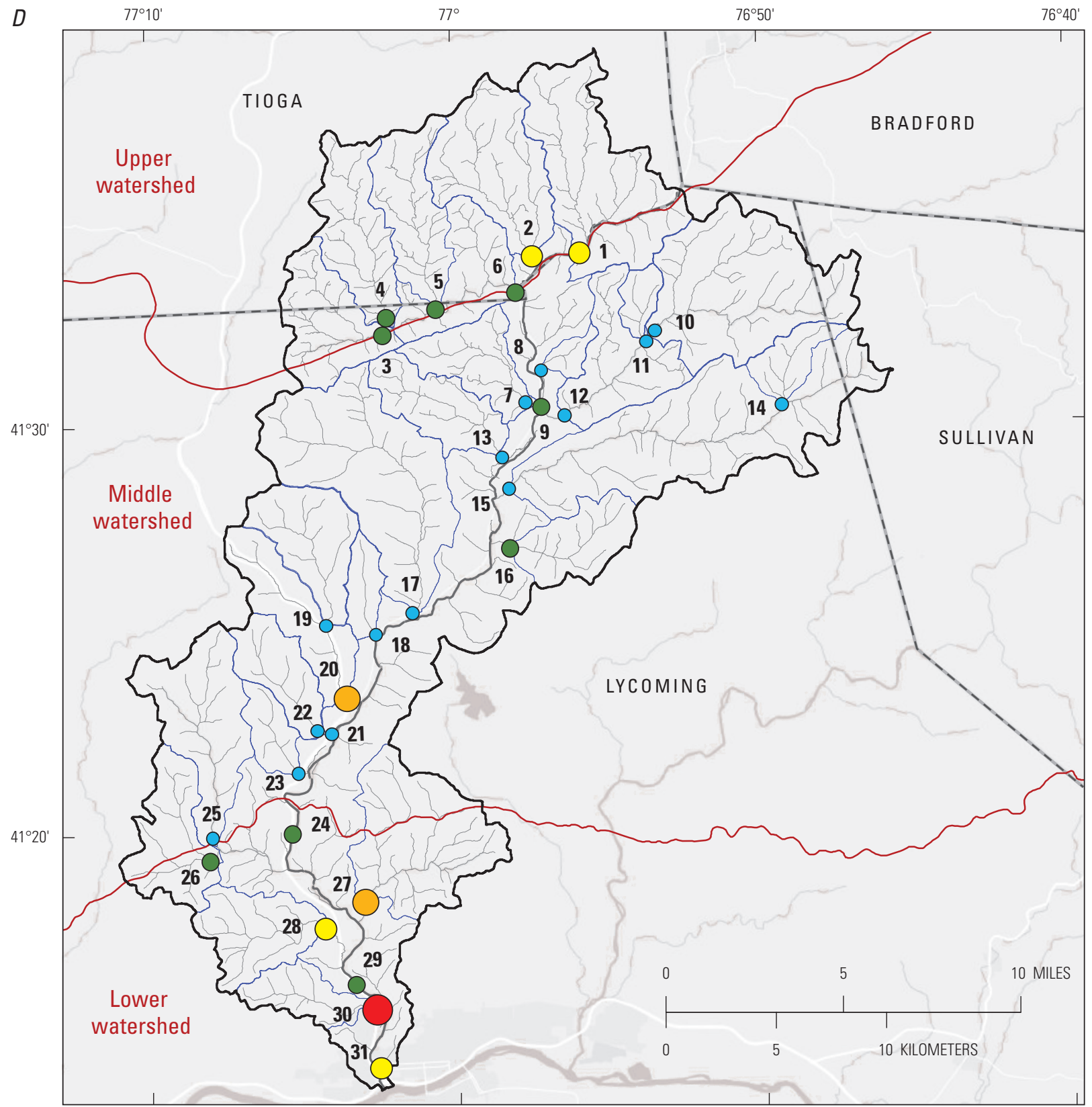

Base map image is the intellectual property of Esri and is used herein under license. Copyright (c) 2014 Esri and its licensors. All rights reserved

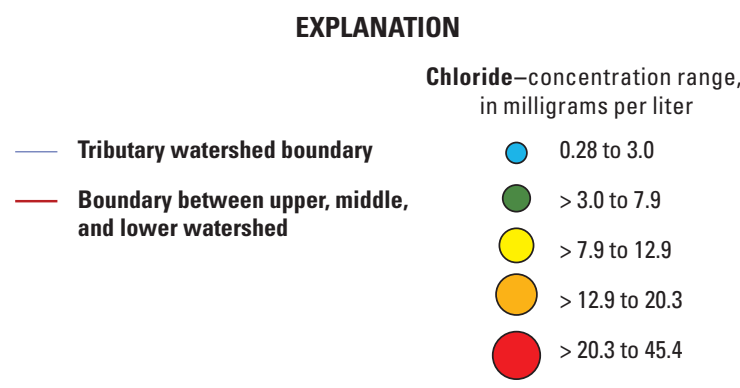

Figure 12D. Spatial variability for $(A)$ total dissolved solids, $(B)$ hardness, $(C)$ acid neutralizing capacity, $(D)$ chloride, $(E)$ barium, $(F)$ strontium, (G) iron, (H) zinc, (/) nitrate, and (J) field pH in the Lycoming Creek, Watershed, August 1-3, 2011. (Sites 1, 9, 24, 29, and 31 are on the main stem of Lycoming (reek)—Contuined 


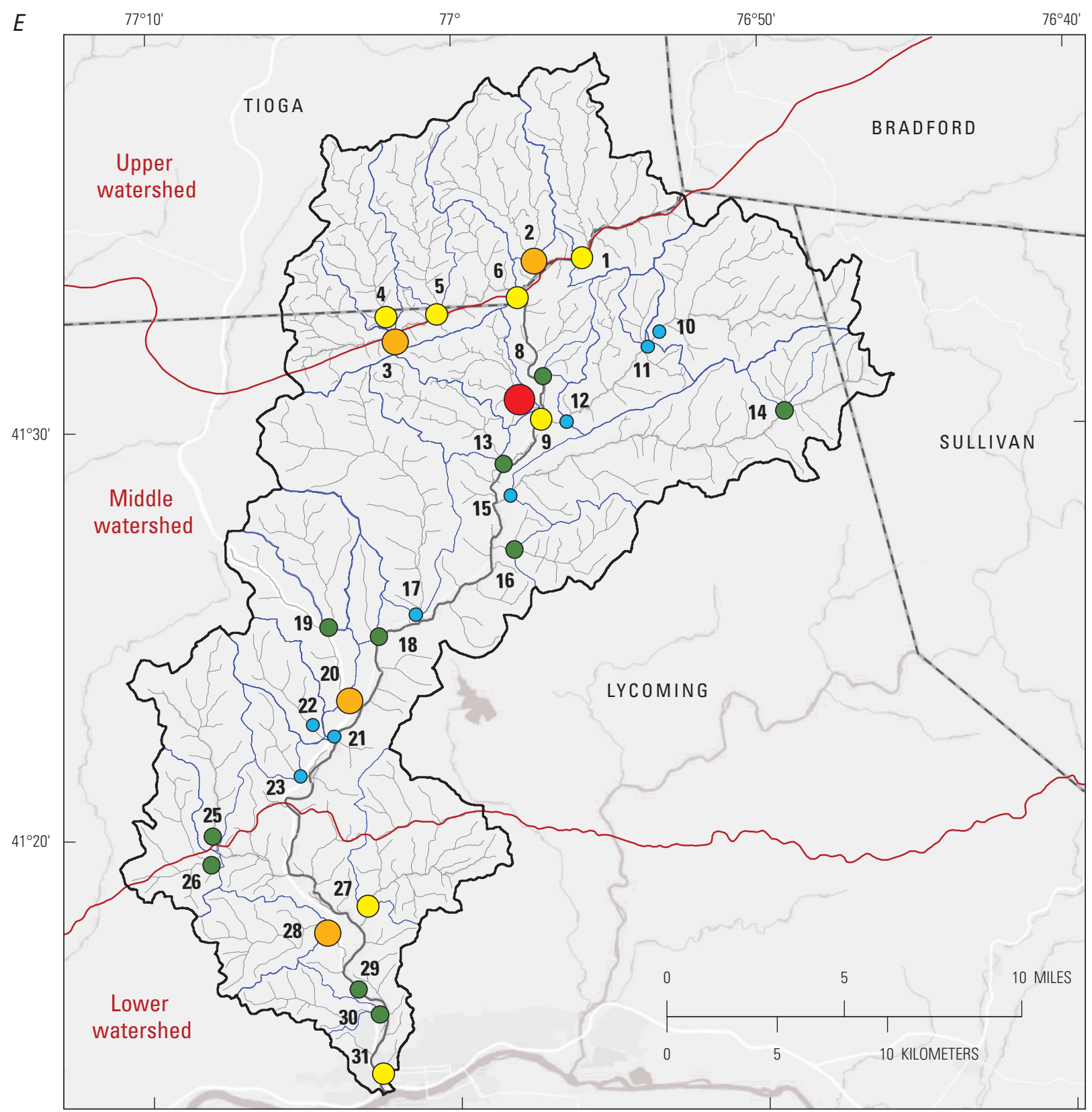

Base map image is the intellectual property of Esri and is used herein under license. Copyright (c) 2014 Esri and its licensors. All rights reserved

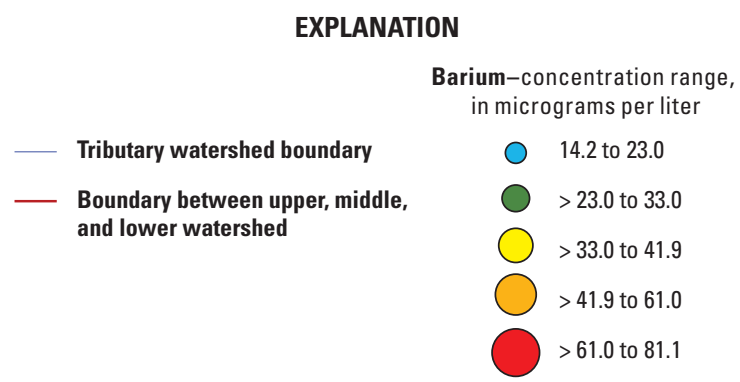

Figure 12E. Spatial variability for $(A)$ total dissolved solids, $(B)$ hardness, $(C)$ acid neutralizing capacity, $(D)$ chloride, $(E)$ barium, $(F)$ strontium, (G) iron, (H) zinc, (/) nitrate, and (J) field pH in the Lycoming Creek, Watershed, August 1-3, 2011. (Sites 1, 9, 24, 29, and 31 are on the main stem of Lycoming (reek)—Contuined 


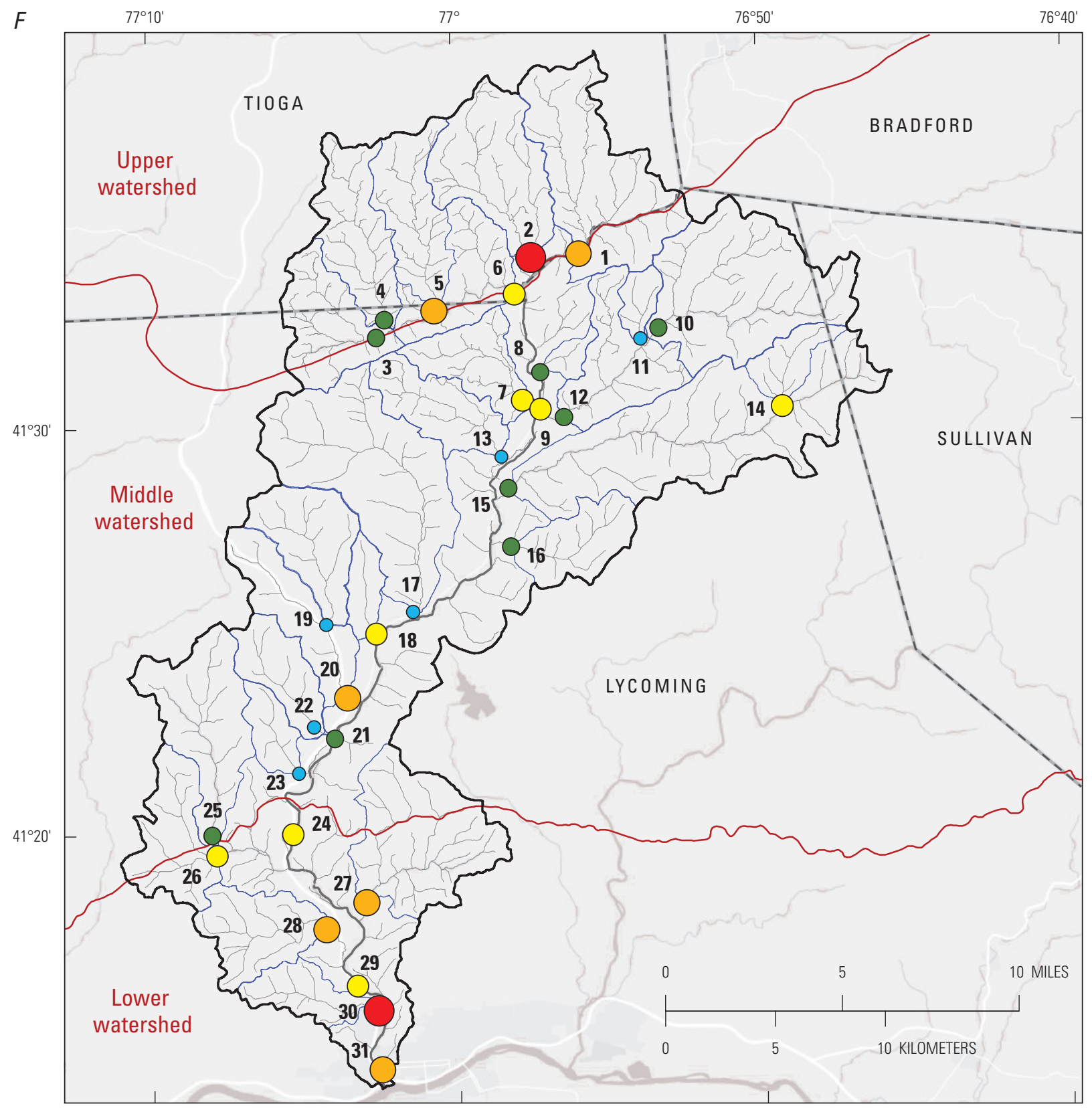

Base map image is the intellectual property of Esri and is used herein under license. Copyright (c) 2014 Esri and its licensors. All rights reserved

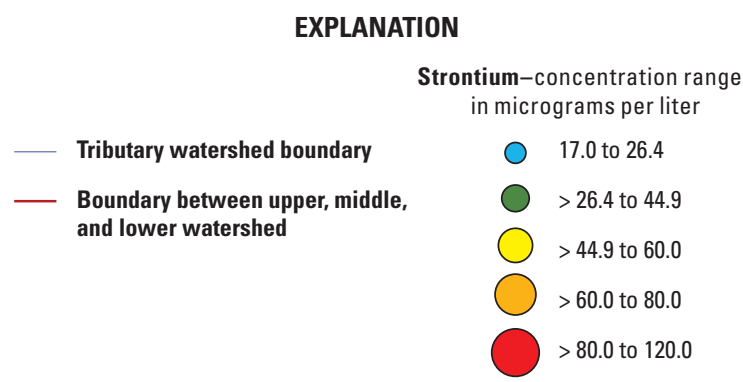

Figure 12F. Spatial variability for $(A)$ total dissolved solids, $(B)$ hardness, $(C)$ acid neutralizing capacity, $(D)$ chloride, $(E)$ barium, $(F)$ strontium, $(G)$ iron, $(H)$ zinc, (/) nitrate, and (J) field pH in the Lycoming Creek, Watershed, August 1-3, 2011. (Sites 1, 9, 24, 29, and 31 are on the main stem of Lycoming (reek)-Contuined 


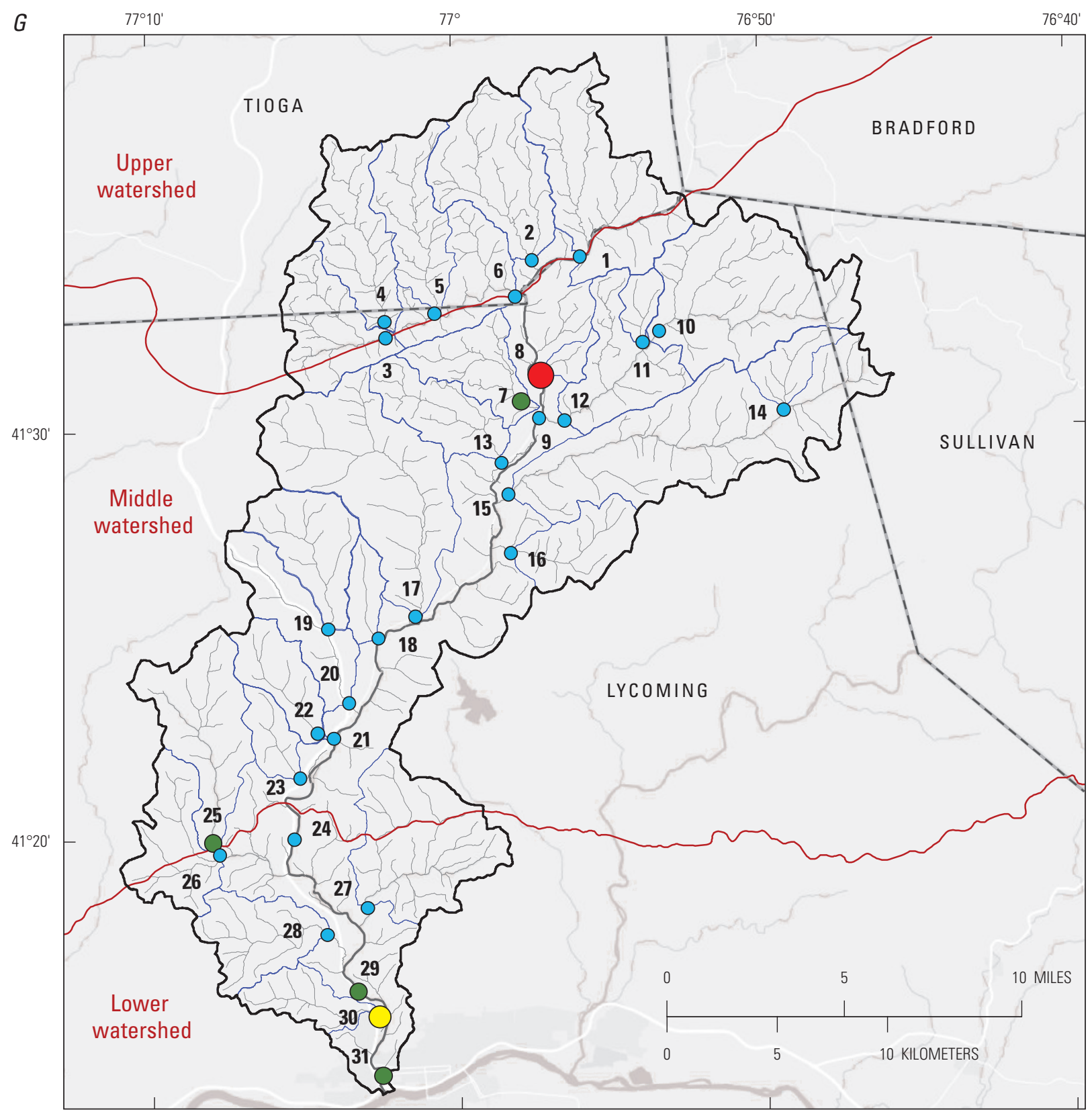

Base map image is the intellectual property of Esri and is used herein under license. Copyright (c) 2014 Esri and its licensors. All rights reserved

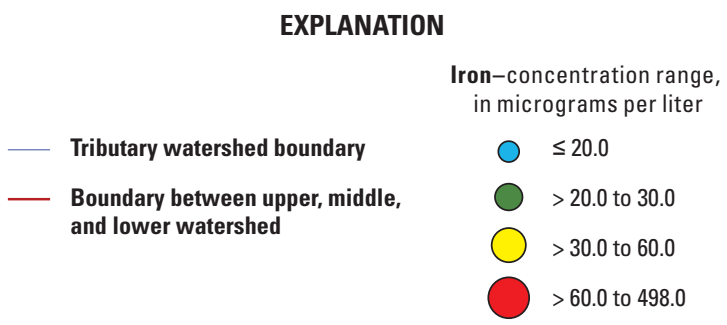

Figure 12G. Spatial variability for $(A)$ total dissolved solids, $(B)$ hardness, $(C)$ acid neutralizing capacity, $(D)$ chloride, $(E)$ barium, $(F)$ strontium, (G) iron, (H) zinc, (/) nitrate, and (J) field pH in the Lycoming Creek, Watershed, August 1-3, 2011. (Sites 1, 9, 24, 29, and 31 are on the main stem of Lycoming Creek) - Contuined 


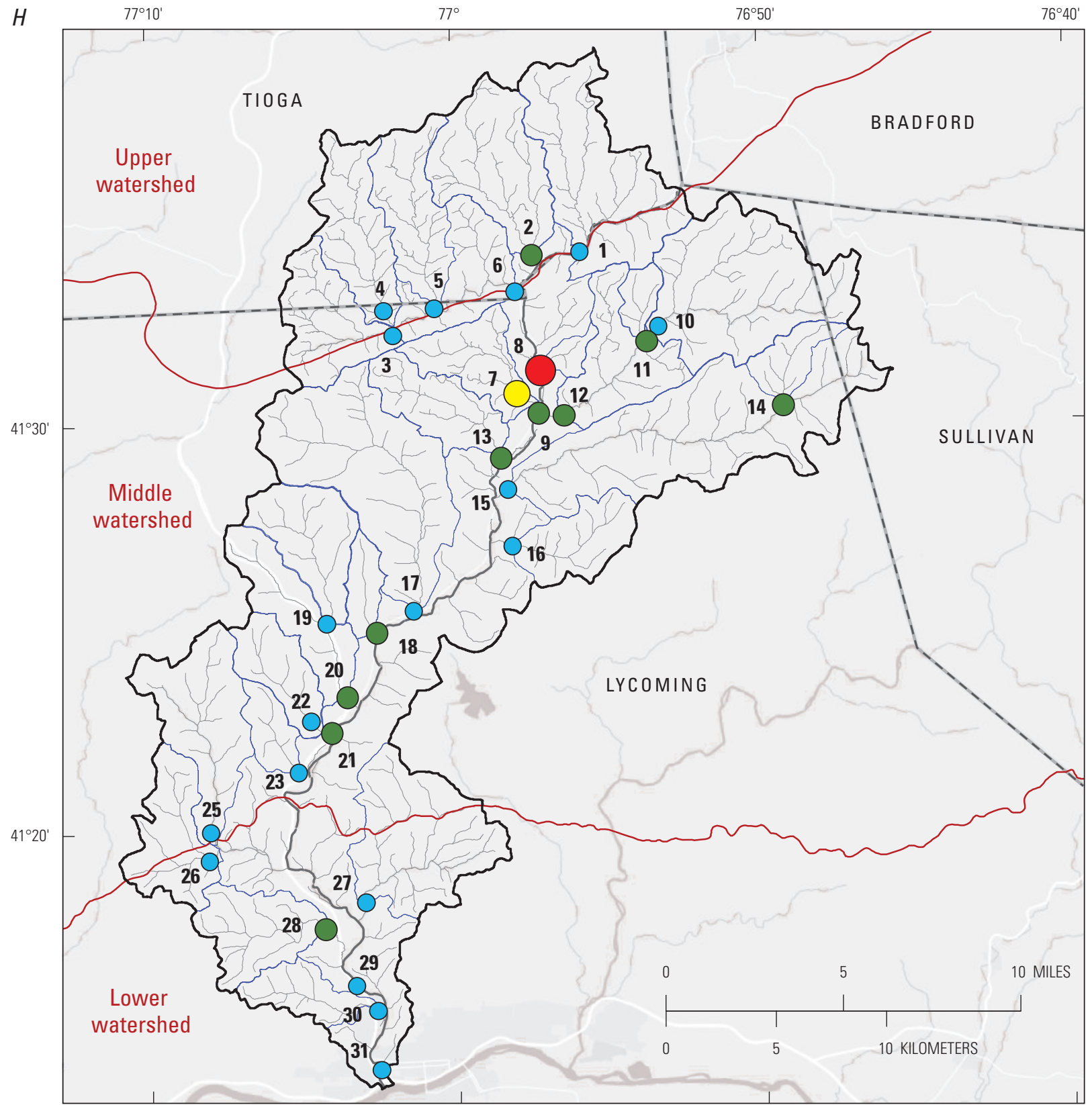

Base map image is the intellectual property of Esri and is used herein under license. Copyright (c) 2014 Esri and its licensors. All rights reserved

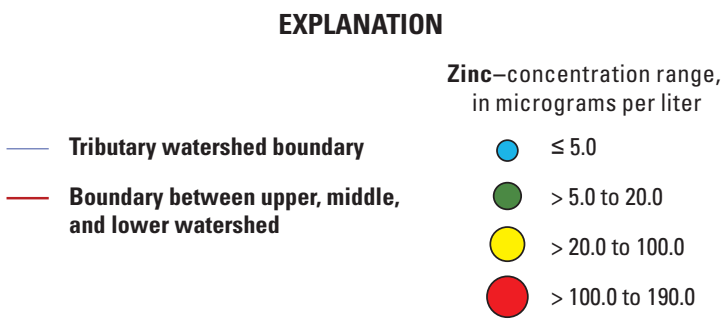

Figure 12H. Spatial variability for $(A)$ total dissolved solids, $(B)$ hardness, $(C)$ acid neutralizing capacity, $(D)$ chloride, $(E)$ barium, $(F)$ strontium, (G) iron, (H) zinc, (/) nitrate, and (J) field pH in the Lycoming Creek, Watershed, August 1-3, 2011. (Sites 1, 9, 24, 29, and 31 are on the main stem of Lycoming (reek)—Contuined 


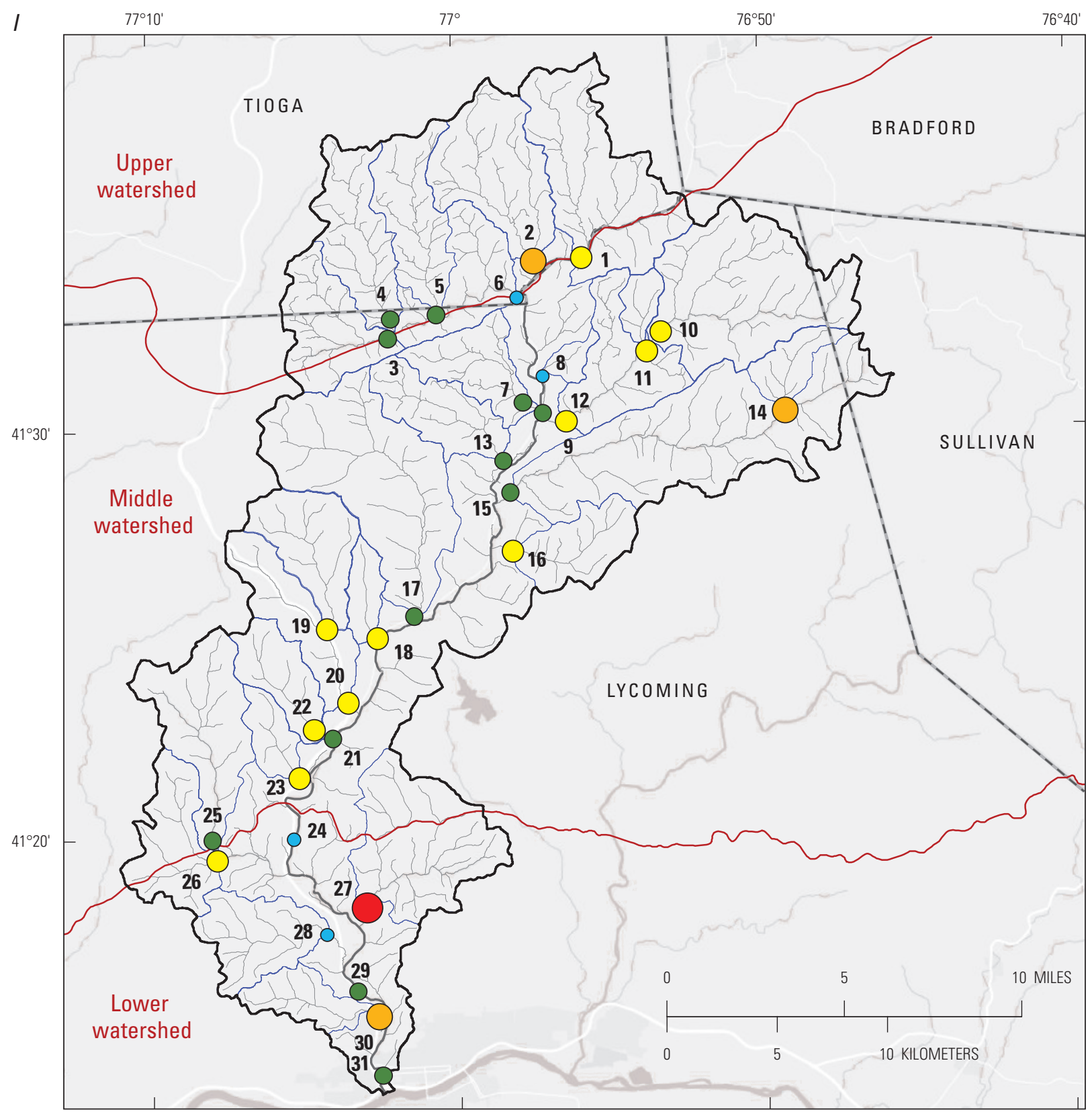

Base map image is the intellectual property of Esri and is used herein under license. Copyright (c) 2014 Esri and its licensors. All rights reserved

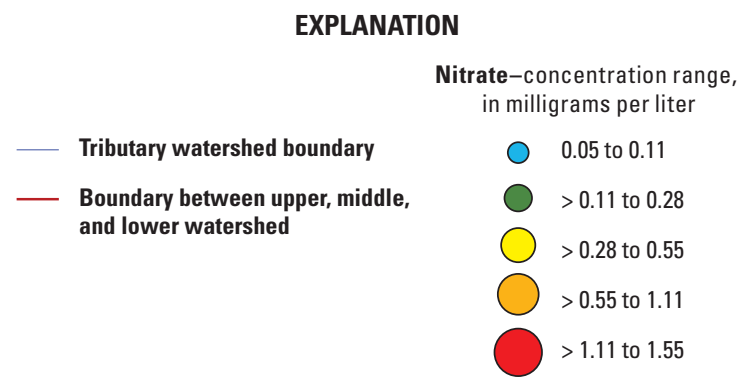

Figure 12I. Spatial variability for $(A)$ total dissolved solids, $(B)$ hardness, $(C)$ acid neutralizing capacity, $(D)$ chloride, $(E)$ barium, $(F)$ strontium, (G) iron, (H) zinc, (/) nitrate, and (J) field pH in the Lycoming Creek, Watershed, August 1-3, 2011. (Sites 1, 9, 24, 29, and 31 are on the main stem of Lycoming (reek)—Contuined 


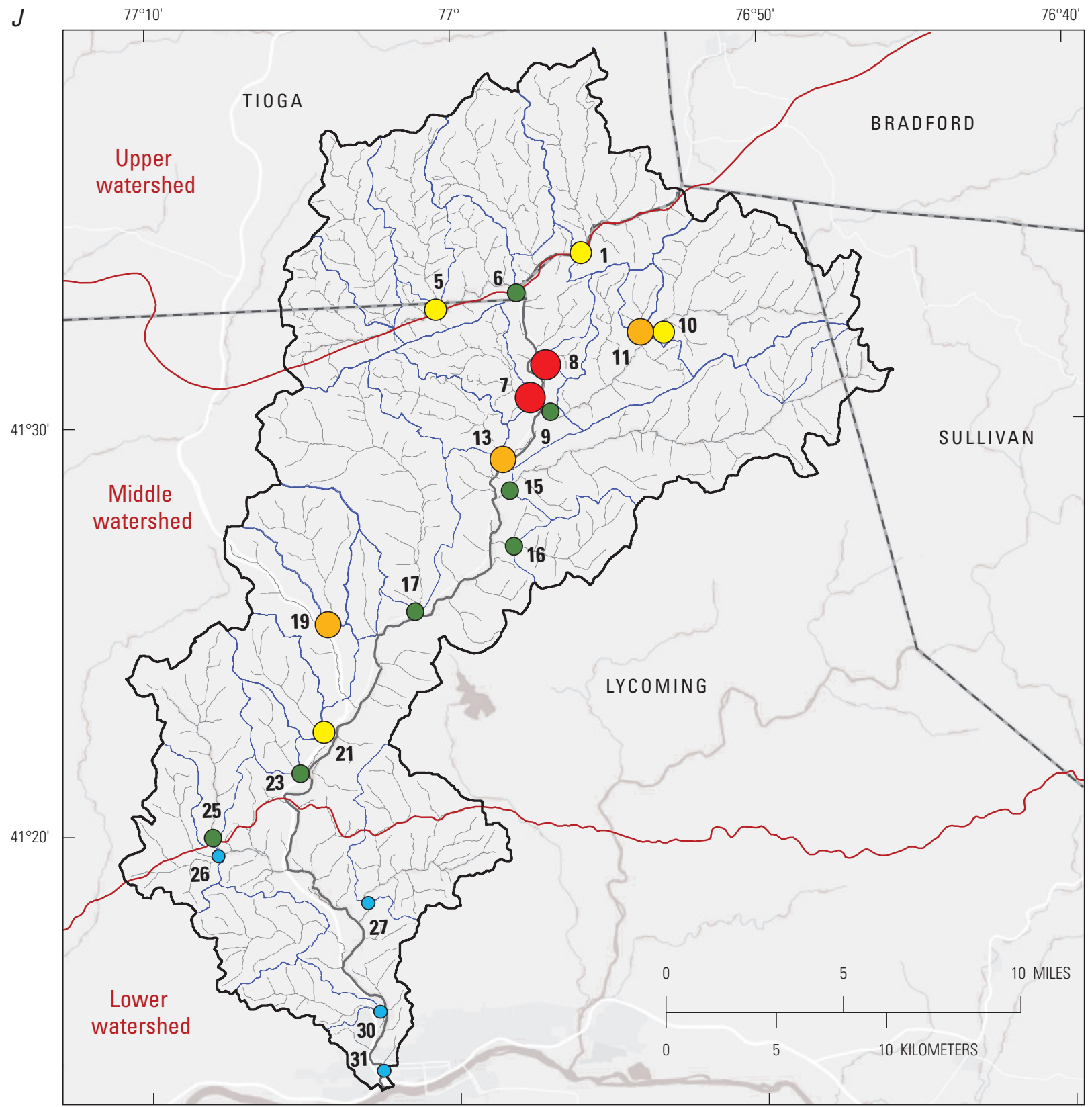

Base map image is the intellectual property of Esri and is used herein under license. Copyright (c) 2014 Esri and its licensors. All rights reserved

\section{EXPLANATION}

\begin{tabular}{|c|c|}
\hline \multirow{5}{*}{$\begin{array}{l}\text { Tributary watershed boundary } \\
\text { Boundary between upper, middle, } \\
\text { and lower watershed }\end{array}$} & 2.8 to 3.9 \\
\hline & $>3.9$ to 5.0 \\
\hline & $>5.0$ to 5.6 \\
\hline & $>5.6$ to 7.0 \\
\hline & $>7.0$ to 8.1 \\
\hline
\end{tabular}

Figure 12J. Spatial variability for $(A)$ total dissolved solids, $(B)$ hardness, $(C)$ acid neutralizing capacity, $(D)$ chloride, $(E)$ barium, $(F)$ strontium, $(G)$ iron, $(H)$ zinc, (/) nitrate, and (J) field pH in the Lycoming Creek, Watershed, August 1-3, 2011. (Sites 1, 9, 24, 29, and 31 are on the main stem of Lycoming Creek)—Contuined 
of hardness from 61 to $120 \mathrm{mg} / \mathrm{L}$. Except for the sample from Dutchman Run, the moderately hard water is found in the lower part of the watershed. The highest value of $89.5 \mathrm{mg} / \mathrm{L}$ was in the sample from Bottle Run. On the main stem of Lycoming Creek the water was categorized as soft in all samples, with concentrations of hardness ranging from 38 to $45.6 \mathrm{mg} / \mathrm{L}$.

\section{Acid-Neutralizing Capacity}

The acid neutralizing capacity (ANC) of samples ranged from 0 to $66 \mathrm{mg} / \mathrm{L}$ as calcium carbonate (fig. 12C). ANC refers to the capacity of solutes and particulates in an unfiltered water sample to neutralize acid (USGS, variously dated, chapter A6). For filtered samples or samples without any particulate matter, ANC is equivalent to alkalinity. The ANC was determined for all samples using either the inflectionpoint titration method by USGS in the field or the fixedendpoint titration by PaDEP in the laboratory; results from the different methods are illustrated together in figure $12 C$. The ANC in stream water from the upper part of Lycoming Creek watershed was fairly similar, with values ranging from 24 to $42 \mathrm{mg} / \mathrm{L}$. In the middle part of the watershed, some streams exhibited very low ANC. Values from four sites-Red Run (site 7), Dutchman Run (site 8), Hounds Run (site 11), and Frozen Run (site 13) — had ANC values less than or equal to $2 \mathrm{mg} / \mathrm{L}$, and 10 other sites had concentrations less than $18 \mathrm{mg} / \mathrm{L}$. The lowest ANC values are in samples from Dutchman Run $(0 \mathrm{mg} / \mathrm{L})$ and Red Run $(0.6 \mathrm{mg} / \mathrm{L})$, watersheds overlying coal seams that been mined in the past; the other sites with low ANC are in watersheds where the soil and rock lack the capacity to neutralize acidic precipitation. The sites with samples having the greatest ANC are in the lower part of the watershed near Williamsport, $54 \mathrm{mg} / \mathrm{L}$ in Beautys Run (site 28) and $66 \mathrm{mg} / \mathrm{L}$ in Bottle Run (site 30). Along the main stem of Lycoming Creek, the ANC was $39 \mathrm{mg} / \mathrm{L}$ near Dogtown (site 1), but decreased substantially to $15 \mathrm{mg} / \mathrm{L}$ downstream at Ralston (site 9), and then increased to $33 \mathrm{mg} / \mathrm{L}$ at 3rd Street Bridge (site 31). The changes in concentration in the main stem are caused mainly by differences in the ANC of water entering from tributary streams.

\section{Chloride}

Concentrations of chloride ranged from 0.28 to $45.4 \mathrm{mg} / \mathrm{L}$ (fig. 12D), but values from 24 of the 31 sites were less than $8 \mathrm{mg} / \mathrm{L}$. The lowest concentrations were found in the middle part of the watershed, where values were less than $3 \mathrm{mg} / \mathrm{L}$ in all except three tributary streams. The notable outlier in the middle watershed is the concentration of $16.2 \mathrm{mg} / \mathrm{L}$ in Trout Run upstream of Lycoming Creek (site 20), which is most likely influenced by road salt applied to U.S. Route 15 . Concentrations in the upper part of the watershed were higher than the middle watershed, ranging from about 4 to $6 \mathrm{mg} / \mathrm{L}$, with a highest value of $11.9 \mathrm{mg} / \mathrm{L}$ in the sample from Mill Creek upstream of Roaring Branch (site 2). Four of the five highest concentrations of chloride in the Lycoming Creek watershed were from streams in the more developed lower part of the watershed. On the main stem of Lycoming Creek, concentrations of chloride in five samples ranged from 6.4 to $12.9 \mathrm{mg} / \mathrm{L}$. Concentrations were greatest at the most downstream site on Lycoming Creek at 3rd Street Bridge (site 31) and lowest from the sample at Ralston (site 9).

\section{Barium}

Concentrations of barium ranged from 14.2 to $81.1 \mu \mathrm{g} / \mathrm{L}$ (fig. $12 E$ ), but values were less than $49 \mu \mathrm{g} / \mathrm{L}$ at all but 5 of 30 sites sampled. The highest barium value of $81.1 \mu \mathrm{g} / \mathrm{L}$ was measured in Red Run (site 7), one of the mining influenced tributaries in the middle part of Lycoming Creek watershed, but at Dutchman Run (site 8), which has also been influenced by mining, barium was only $32.3 \mu \mathrm{g} / \mathrm{L}$. Except for the concentrations of $81.1 \mu \mathrm{g} / \mathrm{L}$ in Red Run and $49.0 \mu \mathrm{g} / \mathrm{L}$ in Trout Run upstream of Lycoming Creek (site 20), concentrations generally were the highest in the upper and lower parts of the Lycoming Creek watershed. On the main stem of Lycoming Creek, concentrations of barium in five samples ranged from 33 to $49.1 \mu \mathrm{g} / \mathrm{L}$; the lowest value was near Heshbon Park (site 29) and the highest at the most upstream site near Dogtown (site 1).

\section{Strontium}

Concentrations of strontium ranged from 17 to $120 \mu \mathrm{g} / \mathrm{L}$ (fig. $12 F$ ). The spatial distribution of strontium values was similar to that found for barium. Samples with values greater than $60 \mu \mathrm{g} / \mathrm{L}$ were all from sites in the upper and lower parts of the watershed except for the sample from Trout Run upstream of Lycoming Creek (site 20). The highest concentrations of strontium were $120 \mu \mathrm{g} / \mathrm{L}$ in Mill Creek upstream of Roaring Branch (site 2), $105 \mu \mathrm{g} / \mathrm{L}$ in Bottle Run (site 30), and $80 \mu \mathrm{g} / \mathrm{L}$ in Beautys Run (site 28) — all streams in watersheds with large percentages of agricultural and some developed lands. On the main stem of Lycoming Creek, concentrations of strontium in five samples were fairly uniform, ranging from 50 to $74.4 \mu \mathrm{g} / \mathrm{L}$. Concentrations were nearly the same ( 73.2 and $74.4 \mu \mathrm{g} / \mathrm{L}$ ) at the most upstream site Lycoming Creek near Dogtown (site 1) and the most downstream site at 3rd Street Bridge (site 31).

Iron

Concentrations of iron in filtered samples ranged from less than $3.2 \mu \mathrm{g} / \mathrm{L}$ to $498 \mu \mathrm{g} / \mathrm{L}$; however, the results were censored to different reporting levels by the USGS and PaDEP laboratories. To illustrate the spatial distribution of iron for all sites, values are censored in figure $12 G$ to the largest common reporting level of $20 \mu \mathrm{g} / \mathrm{L}$. Twenty-five of the thirty-one samples (81 percent) contained iron concentrations less than $20 \mu \mathrm{g} / \mathrm{L}$. Except for concentrations of $498 \mu \mathrm{g} / \mathrm{L}$ in Dutchman Run (site 8) and $56 \mu \mathrm{g} / \mathrm{L}$ in Bottle Run (site 30), the values for the six other sites were less than or equal to $30 \mu \mathrm{g} / \mathrm{L}$. On the main stem of Lycoming Creek, the concentrations of iron were 
all less than $30 \mu \mathrm{g} / \mathrm{L}$, including the main stem site at Ralston (site 9) immediately downstream of the confluence with Dutchman Run.

\section{Zinc}

Concentrations of zinc in filtered samples ranged from less than 1.4 to $190 \mu \mathrm{g} / \mathrm{L}$; however, the results were censored to different reporting levels by the USGS and PaDEP laboratories. To illustrate the spatial distribution of zinc for all 30 sites, values are censored in figure $12 \mathrm{H}$ to the largest common reporting level of $5 \mu \mathrm{g} / \mathrm{L}$. Eighteen of the thirty samples (60 percent) contained zinc concentrations less than the common reporting level of $5 \mu \mathrm{g} / \mathrm{L}$. With the exception of values for the mining-influenced sites of $190 \mu \mathrm{g} / \mathrm{L}$ in Dutchman Run (site 8 ) and $90.4 \mu \mathrm{g} / \mathrm{L}$ in Red Run (site 7), concentrations were all less than or equal to $20 \mu \mathrm{g} / \mathrm{L}$. On the main stem of Lycoming Creek, the only concentration of zinc above the reporting level $(9.9 \mu \mathrm{g} / \mathrm{L})$ was from the sample at Ralston (site 9).

\section{Nitrate}

Concentrations of nitrate ranged from 0.05 to $1.55 \mathrm{mg} / \mathrm{L}$ (fig. 12I). Samples from only four sites, located in different parts of the watershed, had concentrations greater than $0.55 \mathrm{mg} / \mathrm{L}$. Of those four, only the nitrate values of $1.11 \mathrm{mg} / \mathrm{L}$ from Bottle Run (site 30) and $1.55 \mathrm{mg} / \mathrm{L}$ from Mill Creek near Hepburnville (site 27) in the lower part of the watershed exceeded $1.0 \mathrm{mg} / \mathrm{L}$. On the main stem of Lycoming Creek, nitrate values were highest $(0.35 \mathrm{mg} / \mathrm{L})$ at the most upstream site near Dogtown (site 1$)$ and lowest $(0.10 \mathrm{mg} / \mathrm{L})$ at Haleeka (site 24).

\section{Field $\mathrm{pH}$}

The $\mathrm{pH}$ ranged from 2.8 to 8.1 in 20 samples analyzed in the field (fig. 12J). The pH is 5.6 or less in samples from nine streams in the upper and middle parts of Lycoming Creek watershed. The lowest $\mathrm{pH}$ values of 2.8 in Dutchman Run (site 8) and 3.9 in Red Run (site 7) are influenced by weathering of sulfate minerals exposed by past coal mining in those watersheds, but the other seven streams with $\mathrm{pH}$ less than 5.6 are probably influenced mostly by acid deposition and lack of buffering capacity of bedrock in those watersheds. The greatest $\mathrm{pH}$ value of 8.1 was in the sample from Mill Creek near Hepburnville (site 27) in the lower part of the watershed. In samples from three sites on the main stem of Lycoming Creek, pH values were greatest (7.4) at the most downstream site at 3rd Street Bridge (site 31) and lowest (5.4) at the most upstream site near Dogtown (site 1).

\section{Geology and Water Quality}

The quality of surface water in the Lycoming Creek watershed is strongly influenced by the lithology of the bedrock beneath different parts of the watershed. Solutes released by weathering of minerals in the bedrock define the relative composition of major ions (water type), and provide most of the dissolved-solids concentration in the natural base flow. The lithology of the bedrock varies from the mostly fine-grained shale and siltstone in rocks of Middle Devonian age that were deposited in a marine environment, to the coarser-grained, quartz-rich sandstones and conglomerates in rocks of Late Devonian, Mississippian, and Pennsylvanian ages, that were deposited in a mostly nonmarine environment. The resistant, quartz-rich sandstones in the Huntley Mountain Formation and younger formations, exposed mostly in the middle part of Lycoming Creek watershed, are more resistant to weathering than the siltstones and shales in the Catskill Formation and older formations, which are exposed mostly in the upper and lower parts of the watershed (fig. 3).

Concentrations of 18 water-quality constituents from streams in watersheds underlain by 60 percent or more of quartz-rich sandstones (Huntley Mountain Formation and younger formations) were compared to concentrations from streams in the other watersheds underlain by more siltstone and shale (Catskill Formation and older formations) (fig. 13). Samples from streams where the water chemistry has probably been substantially affected by human activities such as mining, road deicing, and urban development were excluded (sites with map identifiers 7, 8, 20, and 30 in table 1), so the comparison would, to the extent possible, reflect differences in water quality related to bedrock lithology. Samples from the four sites on the main stem of Lycoming Creek having upstream watershed areas greater than 30 square miles also were excluded because the water quality at those sites is an integration of the upstream land uses and rock types. Figure $13 \mathrm{~A}$ compares concentrations of 9 constituents from 23 sites where samples were collected by both USGS and PaDEP and concentrations in all samples were equal to or greater than the reporting limit. Figure $13 B$ compares concentrations of 9 trace constituents from 15 sites where samples were collected only by USGS and less than five values were censored at the reporting level. For the purpose of this comparison, the few censored values were replaced with a concentration equal to 0.99 times the censored value for that constituent.

Figure 13 shows that concentrations for most waterquality constituents are lower in watersheds underlain predominantly by the quartz-rich sandstones (Huntley Mountain Formation and younger formations) than from watersheds underlain by siltstone and shale (Catskill Formation and older formations). Statistical analysis using the Wilcoxon rank-sum test (Helsel and Hirsch, 2002) indicates median concentrations were significantly lower in the sandstone formations ( $\mathrm{p}=0.05$ ) for all constituents except aluminum, lithium, and manganese, which were not significantly different. Nickel was significantly higher in watersheds underlain by sandstone. The smaller concentrations of acid-neutralizing capacity, specific conductance, total dissolved solids, hardness, and most dissolved ions in water from the quartz-rich sandstones is a result of the low solubility of quartz and intergranular cementing minerals. The higher concentrations of nickel in water of the quartz-rich sandstone group could be caused by higher nickel 
A. Constituents analyzed by U.S. Geological Survey and Pennsylvania Department of Environmental Protection

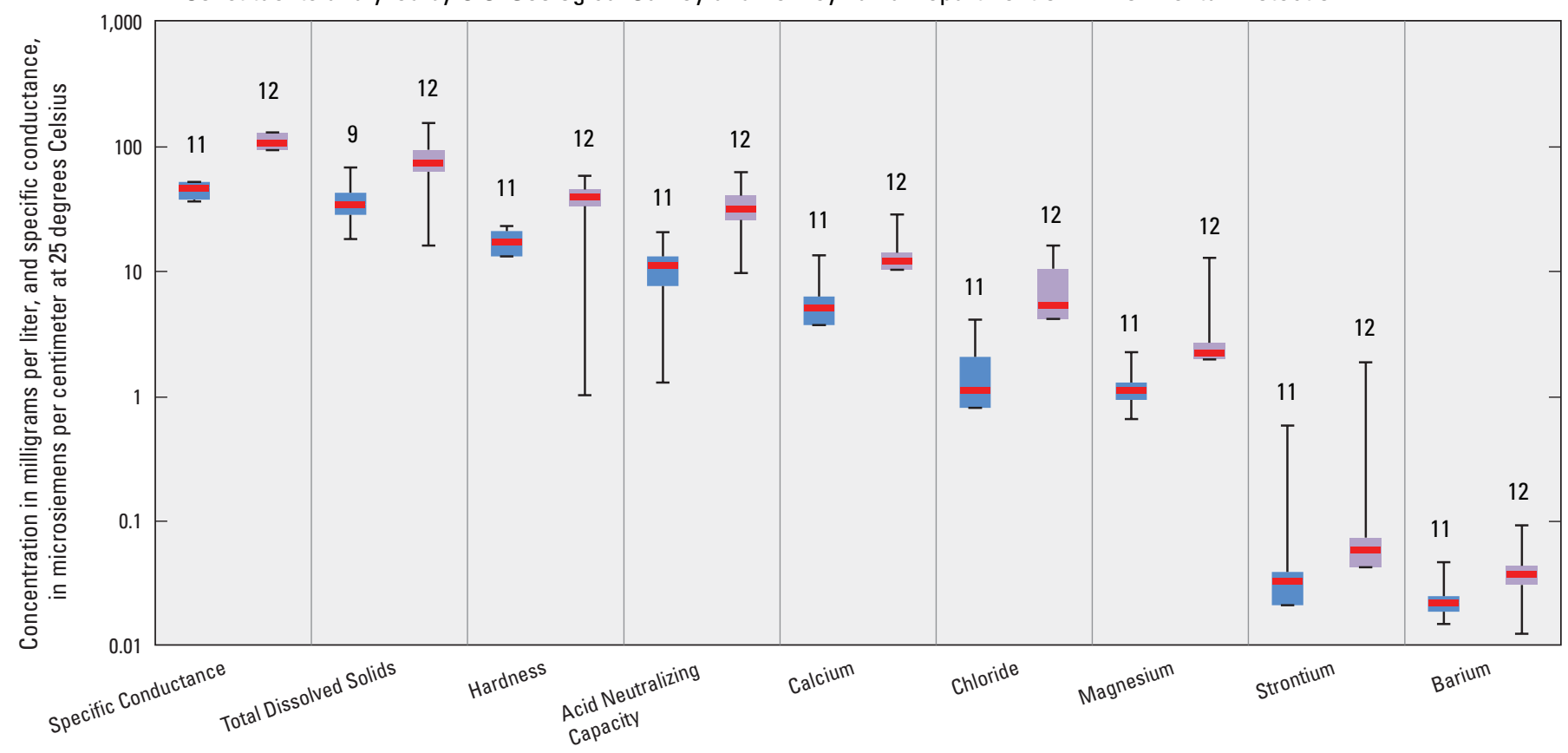

B. Trace elements analyzed by U.S. Geological Survey

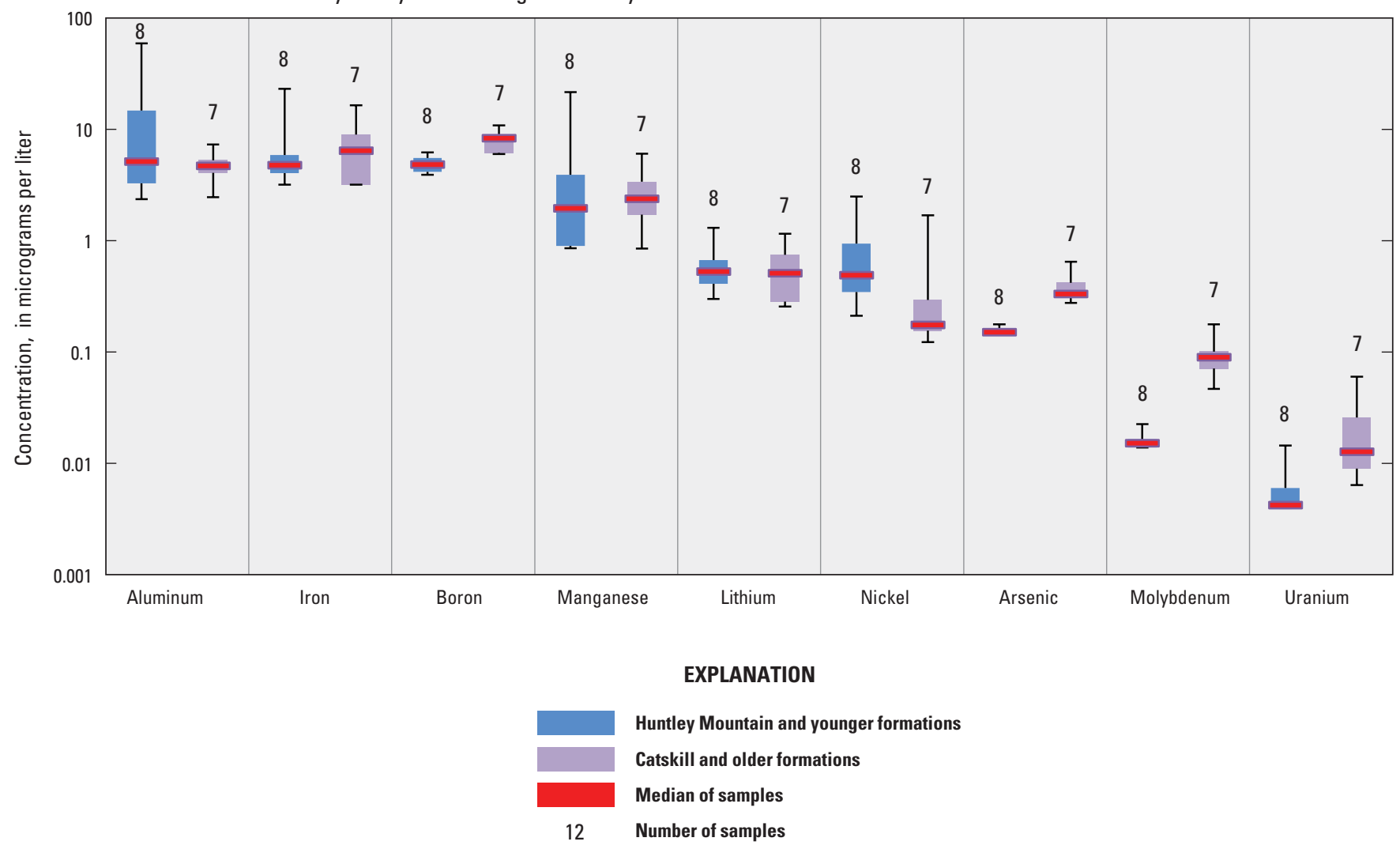

Figure 13. Comparison of concentrations for water-quality constituents from watersheds underlain predominantly by quartz sandstone (60 percent or more Huntley Mountain Formation and younger formations) and watersheds underlain by siltstone and shale (40 percent or more Catskill Formation and older formations) within the Lycoming Creek watershed, August 1-3, 2011 for (A) nine constituents analyzed by both the U.S. Geological Survey (USGS) and the Pennsylvania Department of Environmental Protection, and (B) nine trace constituents analyzed by USGS. 
concentrations in coals present in the Allegheny and Pottsville Formations within that group.

The bedrock geology controls the degree to which acidic deposition affects base-flow water quality. Precipitation on the Lycoming Creek watershed is acidic, as shown by the mean $\mathrm{pH}$ of 4.81 from 16 precipitation samples collected in 2011 at the atmospheric-deposition monitoring station in Little Pine State Park about 9 miles west of the Lycoming Creek watershed (National Atmospheric Deposition Program, 2015). Weathering of carbonate and clay minerals from the bedrock helps to neutralize the acidity and buffer the water. Those minerals, in general, occur in greater amounts in the fine-grained shales and siltstones than in the quartz-rich sandstones. In the Lycoming Creek watershed, the ANC of surface-water samples from watersheds underlain predominantly by quartzrich sandstones (and not substantially affected by mining) ranged from 1 to 20 and were significantly lower as a group than from watersheds underlain by more siltstone and shale, where field ANC ranged from 11 to 54 (fig. 13A). For streams in the middle part of the Lycoming Creek watershed that are underlain by sandstones with few carbonate or clay minerals, the ANC of stream base flow is low and acid deposition is likely a major source of the acidity (fig. 13A).

\section{Land Use and Water Quality}

Human activities on the landscape influence the quality of surface water in Lycoming Creek watershed. The waterquality characteristics associated with agricultural lands and developed lands are described along with the characteristics associated with historical coal mining and oil and gas development. Percentages of agricultural and developed lands in the watershed upstream from each sample site are shown in figure 10. Watersheds of tributary streams in the middle part of Lycoming Creek watershed are almost entirely forested, whereas those in the upper and lower parts of the watershed have more agriculture and developed lands.

\section{Agriculture}

Agricultural lands account for 12.5 percent of the Lycoming Creek watershed. Although every tributary watershed with the exception of Dutchman Run (site 8) contains some degree of farming activity, agriculture is found mostly in the upper and lower parts of the watershed and along the main stem of the Lycoming Creek (figs. 4 and 10). Tributary watersheds with the most agriculture as a percentage of total area are Beautys Run (site 28) with 50 percent agriculture, and Mill Creek near Hepburnville (site 27) with 46 percent agriculture, both of which are in the lower part of Lycoming Creek watershed.

Agricultural activities are sometimes associated with increased nutrients in stream base flow (Lindsey and others, 1997). Elevated levels of nitrogen and phosphorus compounds are commonplace in heavily farmed areas where fertilizers are used to increase crop outputs, and excess nutrients that are not taken up by plants can be carried to streams though sediment erosion or infiltrate into groundwater and cause elevated nutrient concentrations during base-flow periods. Of the 20 sites sampled by USGS, no samples failed to meet the MCL for nitrate of $10 \mathrm{mg} / \mathrm{L}$ as nitrogen. There were 12 samples that contained total nitrogen above $0.3 \mathrm{mg} / \mathrm{L}$, the estimated background concentration for the region (Dubrovsky and others, 2010, p. 118). These sites are spread among tributary watersheds with differing amounts of agriculture, but the two highest values - $1.8 \mathrm{mg} / \mathrm{L}$ at Mill Creek near Hepburnville (site 27) and $1.4 \mathrm{mg} / \mathrm{L}$ at Bottle Run near Williamsport (site 30) - are from watersheds with more than 35 percent agricultural lands, though inputs from other sources (such as on-lot septic and lawn fertilizers) could also contribute nutrients, especially in the Bottle Run watershed.

Total phosphorus in base flow from the 20 sites sampled by USGS was greater than the estimated natural background concentration of $0.01 \mathrm{mg} / \mathrm{L}$ (Dubrovsky and others, 2010, p. 118) at three sites. Stoney Gap Run near Quiggleville (site 26), Mill Creek near Hepburnville (site 27), and Bottle Run near Williamsport (site 30) had concentrations of 0.021, 0.041 , and $0.037 \mathrm{mg} / \mathrm{L}$, respectively; they are all in the lower watershed and have more than 25 percent of their land devoted to crops and pasture. Other sites may have had concentrations above background levels, but the reporting limit of phosphorus for NWQL was $0.02 \mathrm{mg} / \mathrm{L}$, twice that of the estimated background concentration level.

\section{Residential and Commercial Development}

Only about 4.7 percent of the Lycoming Creek watershed is classified as developed. There is little development in the upper parts of the basin, except for areas directly adjacent to the main stem of Lycoming Creek. Development is concentrated in the lower part of the basin, accounting for just more than 15 percent of total land usage. The Bottle Run watershed contains the highest level of development (11.4 percent) of the watersheds sampled.

The development of land for residential or commercial purposes may lead to elevated levels of certain constituents in base flow, such as chloride and boron. Sources of chloride include road salt, water-conditioning salts, and waste from onlot septic systems and various manufacturing processes. Boron is commonly elevated in septic effluent because it is an additive in some laundry detergents. Chloride $(\mathrm{p}=0.003)$ and boron $(\mathrm{p}=0.0001)$ are both found in statistically significant higher concentrations in these regions compared to the more forested areas. Bottle Run (site 30) contained elevated levels of both chloride $(45.4 \mathrm{mg} / \mathrm{L}$ compared to a median of $3.8 \mathrm{mg} / \mathrm{L})$ and boron $(14.9 \mu \mathrm{g} / \mathrm{L}$ compared to a median of $6.1 \mu \mathrm{g} / \mathrm{L})$. The three tributary watersheds with the highest boron concentrations - $14.9 \mathrm{mg} / \mathrm{L}$ in Bottle Run (site 30), $10.8 \mathrm{mg} / \mathrm{L}$ in Mill Creek near Hepburnville (site 27) and $9.7 \mathrm{mg} / \mathrm{L}$ in Lycoming Creek at Third Street Bridge, Williamsport (site 31) - are all in the most developed (lower part) of the basin. 
Chloride and bromide commonly are used as indicators of dilution or mixing of waters because of the conservative nature of these anions; once dissolved, they are not easily removed from solution by precipitation, ion exchange, or other reactions (Davis and others, 1998). The ratio of chloride to bromide found in fresh water is usually less than 100:1, road de-icing mixtures are about 5,000:1 to 10,000:1, and flowback brines from oil and gas wells are about 100:1 (Whittemore, 2007). The differences in the ratios can be used to help identify the source of chloride because the mixing of different sources of water causes a change in the chloride/bromide ratio in direct proportion to the mass loading from each source. Samples from the Lycoming Creek watershed plot close to the theoretical mixing curve for freshwater and road de-icing salts (fig. 14); indicating that the source of chloride at the sample points is probably derived from de-icing salts. Infiltration of snowmelt may recharge the groundwater system with elevated levels of chloride during the winter, leading to the discharge of these salts months (or years) later in the base flow of the streams.

\section{Mining}

Bituminous coal has been extracted in the past from parts of the Lycoming Creek watershed by both surface and underground mining. The areas underlain by coal deposits, mainly in the Allegheny Formation and, to a lesser extent in the Pottsville Formation, are shown in figure 5. The presence of past surface mining is evident on topographic maps within six tributary watersheds where water samples were collected. Strip mines are shown on maps within the Dutchman Run, Red Run, and Rock Run watersheds, and in small areas along the topographic divides of Frozen Run, Hoagland Run, and Stoney Gap Run watersheds. Land usage for these areas is typically classified as barren whether or not reclamation efforts have occurred.

Water samples from Dutchman Run (site 8) and Red Run (site 7) show evidence of impacts from coal mining. The relative proportion of major ions illustrated on the Stiff diagram (fig. 11) shows that waters from Dutchman Run and Red Run are enriched in sulfate and magnesium compared to samples from other basins. Samples from Frozen Run (site 13) and Hounds Run (site 11) are also relatively enriched in sulfate, but because of the very low concentration of dissolved solids in those waters (less than $20 \mathrm{mg} / \mathrm{L}$ ), it is possible that the sulfate is from atmospheric deposition and naturally weathered sulfide minerals in the rocks rather than from the impacts of coal mining. The samples from Frozen Run and Hounds Run do not contain the high dissolved solids concentration that is typical of coal-mine drainage.

The field $\mathrm{pH}$ values of 2.8 at Dutchman Run (site 8) and 3.9 at Red Run (site 7) were the lowest measured in the Lycoming Creek watershed. The median field $\mathrm{pH}$ of all watersheds sampled was 6.0, with a trend of waters becoming more neutral to slightly basic from north to south through the basin. Low $\mathrm{pH}$ waters can be the result of coal-mine drainage, acid deposition, and other factors. Dutchman Run and Red Run, which drain resistant Mississippian and Pennsylvanian-age sandstones, had low acid neutralizing capacities and elevated levels of several trace metals indicative of a mining history. Compared to the other tributaries, water samples from Red Run and Dutchman Run were statistically different for $\mathrm{pH}$, ANC, sulfate, aluminum, beryllium, chromium, cobalt, copper, lead, lithium, manganese, nickel, selenium, and zinc (fig. 15).

The impact of coal mining is also apparent in the sample from the main stem of Lycoming Creek at Ralston (fig. 16). The sample from Lycoming Creek near Dogtown (site 1) is upstream of any coal mining; the site at Ralston (site 9) is immediately downstream of Dutchman Run and Red Run, and the site at 3rd Street Bridge (site 31) is near the mouth of Lycoming Creek. Compared to the upstream and downstream samples, the sample from Lycoming Creek at Ralston had a lower acid neutralizing capacity and higher concentrations of sulfate and other trace metals. This shows that inputs of mining-affected waters, even small amounts (but with high concentrations), can affect the concentrations of constituents in the main stem. Farther downstream in Lycoming Creek at the Third Street Bridge, ANC is higher and concentrations of sulfate and most trace metals are lower when compared to the sample at Ralston. The addition of waters from tributaries draining forested watersheds in the middle part of the basin leads to lower concentrations of many constituents at the mouth of the river.

\section{Oil and Gas Development}

Oil and gas development has the potential to affect surface-water quality from accidental spills, improper disposal of wastes, leaking wells, and land disturbance (Abdalla and others, 2011). The Pennsylvania Department of Environmental Protection (2016a) listed only six conventional vertical gas wells (all plugged) in the watershed prior to development of natural gas from the Marcellus Shale in 2007. At the time of this study on August 1, 2011, sixty-five unconventional wells had been drilled in the Lycoming Creek watershed to extract natural gas from the Marcellus Shale. About equal numbers of wells had been drilled in the upper and middle sections of the watershed and nearly all were west of the Lycoming Creek (fig. 5). The greatest density of gas wells ( 1.22 wells per square mile) was in Red Run watershed (table 3).

The flowback and produced waters from Marcellus gas wells contain high levels of dissolved solids in concentrations that greatly exceed levels found in natural surface waters. Hayes (2009) reported concentrations of many chemical constituents in flowback waters at 5 days after hydraulic fracturing, including total dissolved solids ( 38,500 to $238,000 \mathrm{mg} / \mathrm{L})$, chloride ( 26,400 to $148,000 \mathrm{mg} / \mathrm{L}$ ), bromide (185 to $1,190 \mathrm{mg} / \mathrm{L}$ ), strontium (345 to $4,830 \mathrm{mg} / \mathrm{L}$ ), and barium (21 to $13,900 \mathrm{mg} / \mathrm{L}$ ), and lithium (10.6 to $153 \mathrm{mg} / \mathrm{L}$ ). These constituents are some commonly cited indicators of brine contamination (Betanzo and others, 2016). Brines from Marcellus gas wells have also been reported to contain elevated levels of the radioactive element radium (Rowan and others, 2011). 


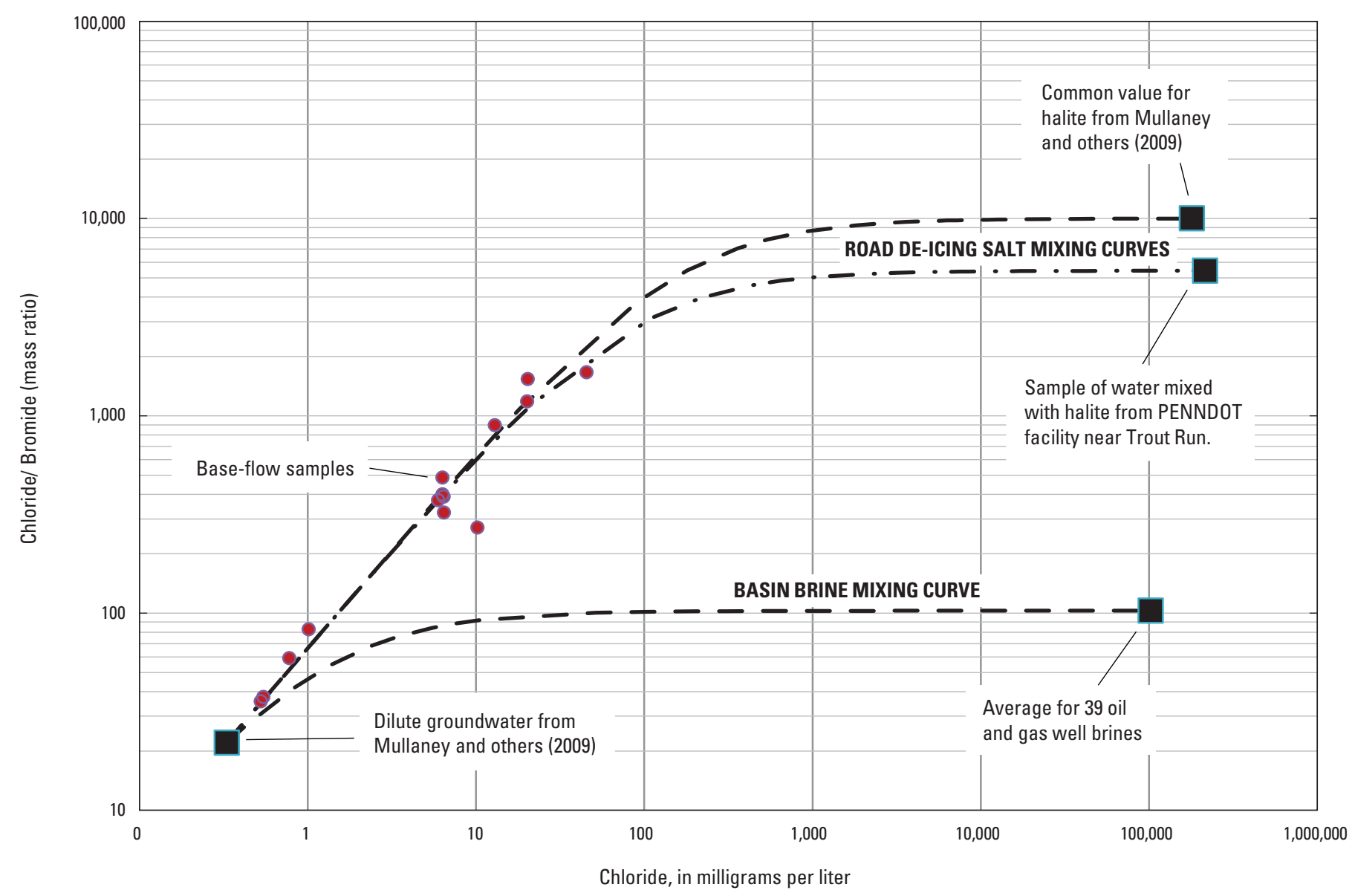

Figure 14. Relation between bromide and chloride concentrations for 14 base-flow samples from the Lycoming Creek watershed, north-central Pennsylvania, August 1-3, 2011 compared to theoretical mixing curves for freshwater with basin brine and road de-icing salts.

Concentrations in base-flow samples collected in the Lycoming Creek watershed ranged from $<12$ to $202 \mathrm{mg} / \mathrm{L}$ for total dissolved solids, 0.28 to $45.4 \mathrm{mg} / \mathrm{L}$ for chloride, $<0.01$ to $0.038 \mathrm{mg} / \mathrm{L}$ for bromide, 0.017 to $0.120 \mathrm{mg} / \mathrm{L}$ for strontium, 0.0142 to $0.0811 \mathrm{mg} / \mathrm{L}$ for barium, 0.00026 to $0.0492 \mathrm{mg} / \mathrm{L}$ for lithium, and $<0.1$ to $2.1 \mathrm{pCi} / \mathrm{L}$ for gross alpha activity. These ranges do not indicate contamination from oil-and-gas brines in any of the streams that were sampled. The calcium-bicarbonate and calcium-sulfate water types of the surface-water samples (fig. 11) did not indicate mixing with a sodium-calcium-chloride type brine from an oil and gas well (Dresel and Rose, 2010). The surface-water samples had chloride/bromide ratios more indicative of a source of chloride from road-salt than from deep basin brine (fig. 14).

Although brine releases to streams can cause degradation of stream quality, constituents that are found at high concentrations in brines may already be present during natural flow conditions. Road salt, as well as agricultural runoff and on-lot septic systems, are common sources of increased levels of chloride. Runoff and groundwater discharge from previously mined regions can contain high levels of total dissolved solids and metals such as arsenic and bromide. Fertilizers can be a source of barium and sometimes radium. A list of constituents that homeowners with private water supplies should consider having analyzed prior to any oil or gas drilling has been developed by the Pennsylvania Department of Environmental Protection (2016b).

\section{Stream Discharge and Water Quality}

This study provided a snapshot of water-quality conditions measured during a relatively stable base-flow condition of stream discharge across the Lycoming Creek watershed. The concentrations of most constituents would differ from the values reported in this study if samples were collected during periods of higher or lower flow. An example of the variability in the specific conductance is shown for samples collected at different discharges in Lycoming Creek near Trout Run, Pennsylvania (01550000) as part of the Pennsylvania Water-Quality Network (fig. 8). There is considerable scatter in the data, but also a decreasing trend in specific conductance with increasing discharge. Understanding the natural variability of constituent concentrations in surface waters will be needed to determine 


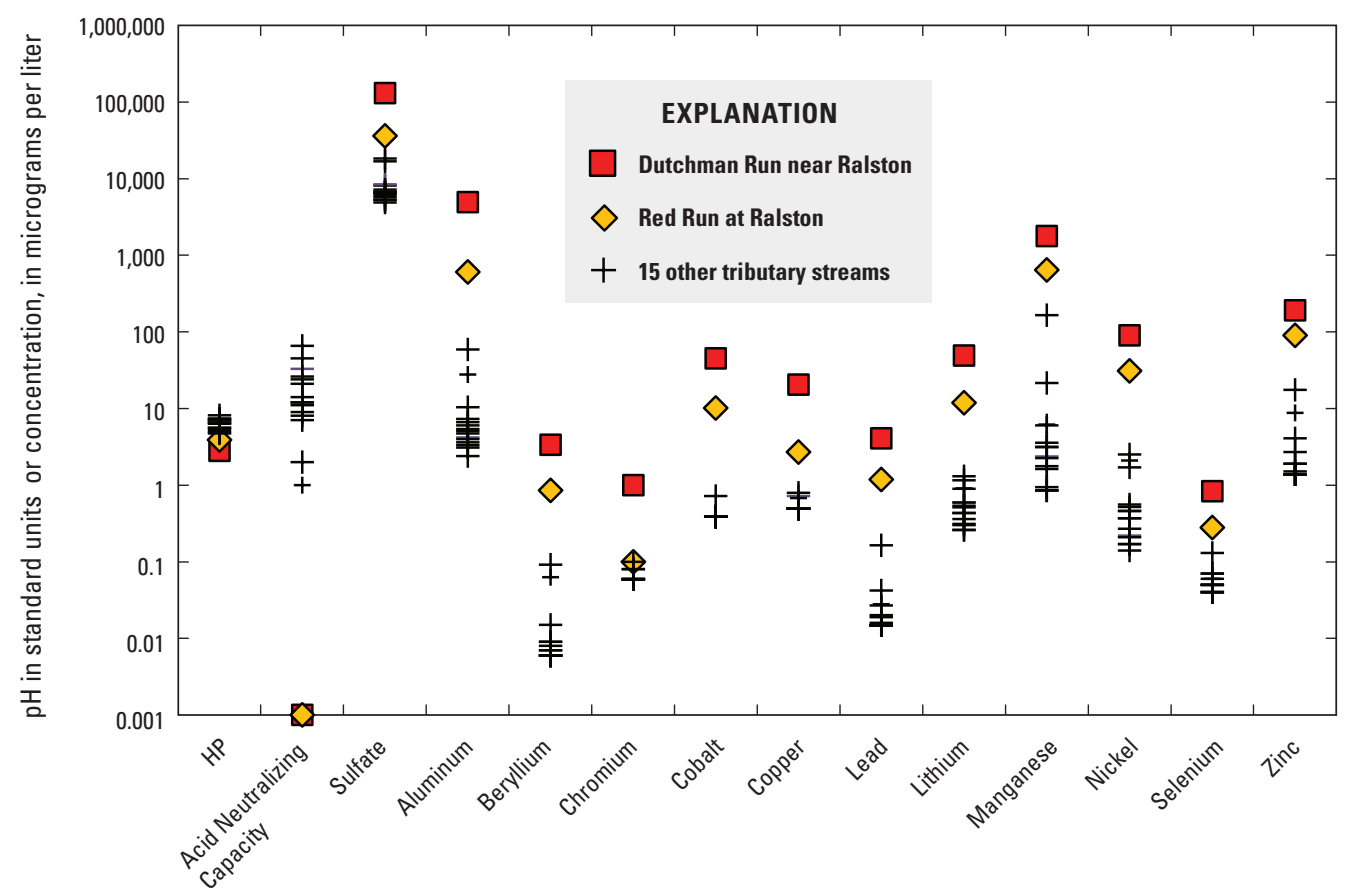

Figure 15. Constituents that were elevated in water samples from Dutchman Run near Ralston and Red Run at Ralston compared to results from samples from 15 other tributary streams in Lycoming Creek watershed, north-central Pennsylvania.

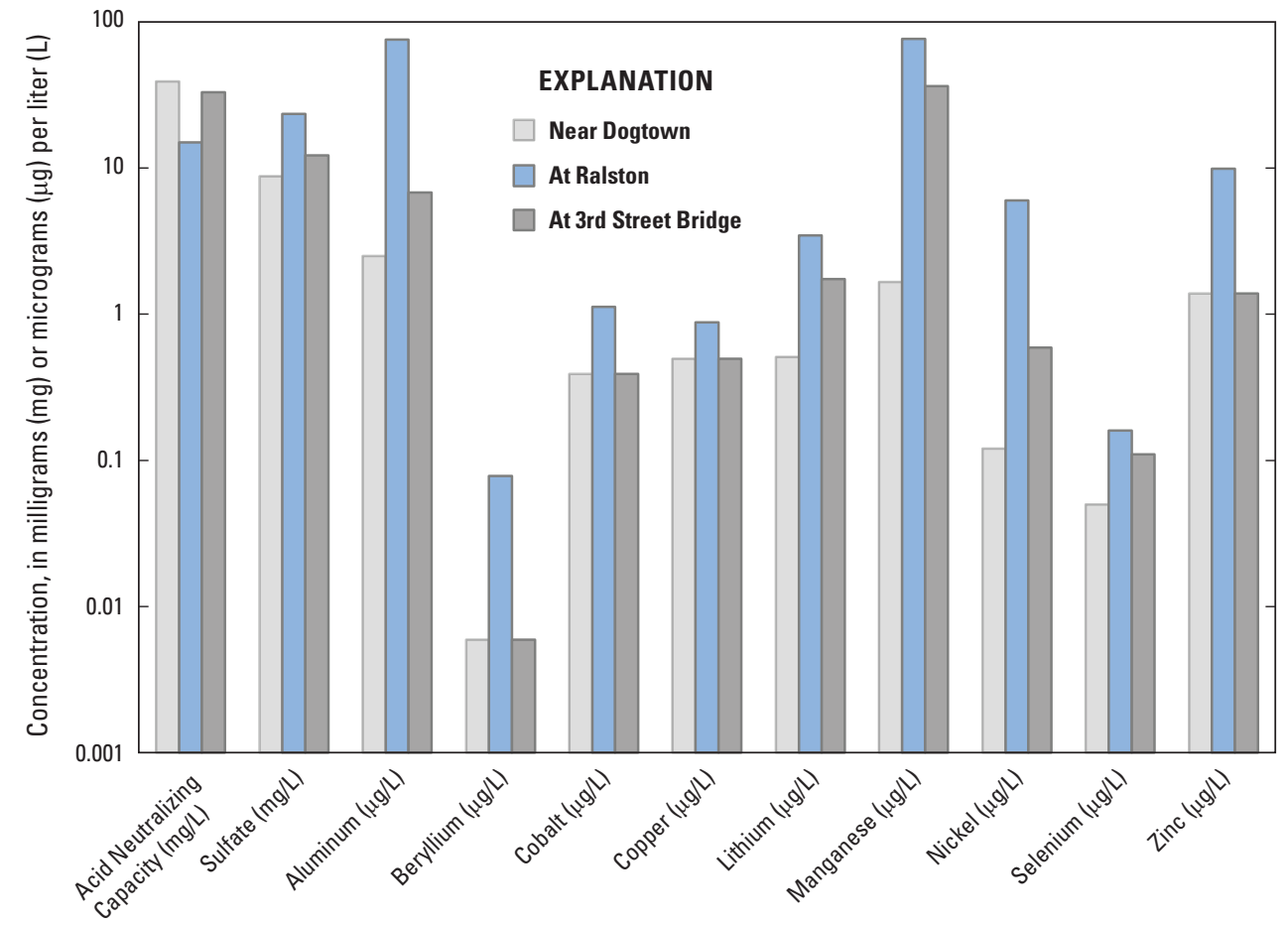

Figure 16. Comparison of selected water-quality constituents associated with coal mining at three sites on the main stem of Lycoming Creek, north-central Pennsylvania, August 1-3, 2011. 
the effect of human activities on water quality; this will require the collection of multiple samples over time at various discharges. In a study designed to detect water-quality changes caused by shale-gas development or other land uses, monthly sampling is recommended for multiple years (Betanzo and others, 2016).

\section{Summary}

This report describes a survey of surface-water quality in the 272-square mile Lycoming Creek watershed within Lycoming, Tioga, and Sullivan Counties in north-central Pennsylvania. The quality of water in Lycoming Creek is of interest to the Williamsport Municipal Water Authority (WMWA) because Lycoming Creek is a source of water to their production wells, which are located near its mouth. The wells capture stream water that infiltrates through the bed of the creek, so the quality of the produced well water can be affected by changes in stream-water quality.

The study was done in cooperation with the WMWA to establish a water-quality dataset that would help document the spatial variability in constituents and provide a basis for distinguishing contaminants from land-use activities such as natural-gas development, road maintenance, agricultural operations, and urban and suburban development. The focus of this study was on the stream water quality as it relates to drinking water standards, as opposed to aquatic life.

Surface-water samples were collected by the U.S. Geological Survey (USGS) and Pennsylvania Department of Environmental Protection (PaDEP) from 31 sites in the Lycoming Creek watershed during a period of base flow August 1-3, 2011. The samples were analyzed by the USGS National Water Quality Laboratory and the PaDEP Bureau of Laboratories. Five sites were on the main stem of Lycoming Creek, and 26 sites were on tributary streams. Watershed areas upstream from the main-stem sampling sites ranged from $15.6 \mathrm{mi}^{2}$ for the most upstream site near Dogtown to $272 \mathrm{mi}^{2}$ for the most downstream site at the 3rd Street Bridge near the mouth of Lycoming Creek. The other 26 sampling sites were on 22 tributary streams-Roaring Branch, Rock Run, Trout Run, and Wolf Run were each sampled at two sites. Watersheds areas ranged from 1.1 to $30.5 \mathrm{mi}^{2}$ for the tributary streams that were sampled. Sampling sites on tributary streams were selected to represent watersheds with various land uses (forest, agriculture, resource extraction, development) and underlying geology.

The results of sampling show a spatial variability in water quality related to differences in land use and geology. Areas of forested lands (79 percent) are mostly in areas of rugged relief, underlain by sandstone bedrock of Mississippian and Pennsylvanian age in the middle part of the watershed; agricultural lands ( 15 percent) are mostly in the upper and lower parts of the watershed, underlain by siltstones and shales of Devonian age. Residential and commercial development ( 5 percent) is concentrated in the lower part of the watershed in the vicinity of Williamsport. Because the land use and geology are related, spatial differences in water quality are difficult to attribute to a specific rock type or land-use activity. However, except where affected by human activities, tributaries that flowed across siltstones and shales of Devonian age typically had higher concentrations of major constituents and trace metals than tributaries in watersheds underlain predominantly by the more resistant sandstone bedrock of Mississippian and Pennsylvanian age.

Water quality in tributary streams ranged from nearly pristine in forested tributaries of the middle watershed to notably influenced by human activity in areas of past coal mining and urban and suburban development. Tributary watersheds that are mostly forested with little agriculture or development typically had low concentrations of major and trace constituents and nutrients. A water sample from one such watershed, Wolf Run, had a dissolved-solids concentration of less than the laboratory reporting level of $12 \mathrm{mg} / \mathrm{L}$. Two of the tributary streams, Dutchman Run and Red Run, contained elevated levels of several trace metals and had negligible acid neutralizing capacity, most likely due to historical coal mining activity in those areas.

Agriculture accounts for about 15 percent of land use in the Lycoming Creek watershed, and eight of the tributary watersheds in the upper and lower parts of Lycoming Creek watershed have at least 25 percent pasture and crop lands. Two tributaries with more than 35 percent of land in the watershed devoted to agriculture, Mill Creek near Hepburnville and Bottle Run, contained the highest concentrations of total nitrogen of 1.8 and $1.4 \mathrm{mg} / \mathrm{L}$, respectively. However, overall there were no definitive relations between nutrient concentrations in water samples and percentage of land devoted to agriculture.

Developed lands account for only about 5 percent of the area of Lycoming Creek watershed, but the effects of residential and commercial development may be evident in Bottle Run, the tributary site nearest to Williamsport. The Bottle Run watershed has 11 percent of its area classified as developed, making it the most developed tributary in the Lycoming Creek watershed. The water sample from Bottle Run showed elevated levels of several constituents. It had the greatest concentrations of dissolved solids $(202 \mathrm{mg} / \mathrm{L})$, sodium $(25.8 \mathrm{mg} / \mathrm{L})$ boron $(9.7 \mathrm{mg} / \mathrm{L})$, bromide $(0.027 \mathrm{mg} / \mathrm{L})$, arsenic $(0.67 \mathrm{mg} / \mathrm{L})$, and ammonia plus organic nitrogen $(0.29 \mathrm{mg} / \mathrm{L})$ in the study. The elevated concentrations are probably related to its location in an area of residential and commercial development, along with a substantial amount of agriculture (38 percent of its area).

Overall, the quality of water in Lycoming Creek was good near the Lycoming Creek well field, where infiltration from the creek to the well field is most likely. The concentrations in the sample collected at the 3rd Street Bridge were in acceptable ranges when compared to U.S. Environmental Protection Agency's primary or secondary maximum contaminant levels, or any health-based screening levels for the constituents analyzed. Although concentrations of some metals 
and nutrients were greater than background levels in tributary streams affected by coal mining or development, they were diluted in the main stem of Lycoming Creek upstream from the well field.

This study examined concentrations of water-quality constituents during a relatively stable base-flow condition of stream discharge, but concentrations of most constituents would differ if samples were collected during higher or lower streamflow. Understanding the natural variability of constituent concentrations will be needed to determine the effects of human activities on water quality, which will require the collection of multiple samples over time at various discharge rates. Also, to improve the ability to determine spatial differences in water quality and trends, if multiple laboratories are used in future studies (as was the case in this study), samples should be analyzed for the same suite of chemical constituents and results reported to similar low reporting limits.

\section{References Cited}

Abdalla, C.W., Drohan, J.R., Blunk, K.S., Edson, Jessie, 2011, Marcellus Shale wastewater issues in Pennsylvania-current and emerging treatment and disposal technologies: Penn State Extension, College of Agricultural Sciences, 9 p., accessed July 13, 2017, at http://www.highlanddiw. com/uploads/9/8/4/6/9846187/pennstate_marcelluswaste1. pdf.

Back, William, Baedecker, M.J., and Wood, W.W., 1993, Scales in chemical hydrogeology-A Historical Perspective, in Alley, W.M., ed., Regional ground-water quality: New York, Van Nostrand Reinhold, 634 p.

Betanzo, E.A., Hagen, E.R., Wilson, J.T., Reckhow, K.H., Hayes, L., Argue, D.M., and Cangelosi, A.A., 2016, Water data to answer urgent water policy questions-Monitoring design, available data and filling data gaps for determining whether shale gas development activities contaminate surface water or groundwater in the Susquehanna River Basin: Northeast-Midwest Institute Report, 238 p., DOI: 10.13140/ RG.2.1.4051.6885, accessed July 13, 2017, at http://www. nemw.org.

Davis, S.N., Whittemore, D.O., and Fabryka-Martin, J., 1998, Uses of chloride/bromide ratios in studies of potable water: Ground Water, v. 36, no. 2, p. 338-350.

Dresel, P.E., and Rose, A.W., 2010, Chemistry and origin of oil and gas well brines in western Pennsylvania: Pennsylvania Geological Survey, 4th series, Open-File Report OFOG $10-01.0,48 \mathrm{p}$.
Dubrovsky, N.M., Burow, K.R., Clark, G.M., Gronberg, J.M., Hamilton, P.A., Hitt, K.J., Mueller, D.K., Munn, M.D., Nolan, B.T., Puckett, L.J., Rupert, M.G., Short, T.M., Spahr, N.E., Sprague, L.A., and Wilber, W.G., 2010, The quality of our Nation's waters-Nutrients in the Nation's streams and groundwater, 1992-2004: U.S. Geological Survey Circular $1350,174 \mathrm{p}$.

Hayes, Thomas., 2009, Sampling and analysis of water streams associated with the development of Marcellus shale gas, Final Report for the Marcellus Shale Coalition: Gas Technology Institute, Des Plaines, Ill, 249 p.

Helsel, D.R., and Hirsch, R.M., 2002, Statistical methods in water resources: U.S. Geological Survey Techniques of Water-Resources Investigations, book 4, chap. A3, p. $142-147$.

Hem, J.D., 1985, Study and interpretation of the chemical characteristics of natural water: U.S. Geological Survey Water-Supply Paper 2254, 263 p.

Homer, C.G., Dewitz, J.A., Yang, L., Jin, S., Danielson, P., Xian, G., Coulston, J., Herold, N.D., Wickham, J.D., and Megown, K., 2015, Completion of the 2011 National Land Cover Database for the conterminous United StatesRepresenting a decade of land cover change information: Photogrammetric Engineering and Remote Sensing, v. 81, no. 5 , p. 345-354.

Lindsey, B.D., Loper, C.A., and Hainly, R.A., 1997, Nitrate in ground water and stream base flow in the Lower Susquehanna River Basin, Pennsylvania and Maryland: U.S. Geological Survey Water-Resources Investigations Report 97-4146, $78 \mathrm{p}$.

Lloyd, Jr., O.B., and Carswell, L.D., 1981, Groundwater resources of the Williamsport region, Lycoming County, Pennsylvania: Pennsylvania Geological Survey, 4th series, Water Resource Report 51, 69 p.

Miles, C.E., and Whitfield, T.G., comp., 2001, Bedrock geology of Pennsylvania: Pennsylvania Geological Survey, 4th series, dataset, scale 1:250,000.

Mueller, D.K., Schertz, T.L., Martin, J.D., and Sandstrom, M.W., 2015, Design, analysis, and interpretation of field quality-control data for water-sampling projects: U.S. Geological Survey Techniques and Methods, book 4, chap. C4, 54 p., accessed June 19, 2017, at http://dx.doi.org/10.3133/ tm 4 C4.

Mullaney, J.R., Lorenz, D.L., and Arntson, A.D., 2009, Chloride in groundwater and surface water in areas underlain by the glacial aquifer system, northern United States: U.S. Geological Survey Scientific Investigations Report 2009-5086, 41 p. 
National Atmospheric Deposition Program (NRSP-3), 2015, National Trends Network, Site PA52, Little Pine State Park: NADP Program Office, Illinois State Water Survey, University of Illinois, Champaign, accessed August 2, 2016, at http://nadp.sws.uiuc.edu/.

Pennsylvania Department of Conservation and Natural Resources 2016, Bedrock geology, Coal distribution, Oil and gas pools (December 2011), Physiographic sections, and Late Wisconsinan boundary: PaGEODE, Web-mapping application for Pennsylvania GEOlogic Data Exploration, accessed July 20, 2016, at http://www.gis.denr.state.pa.us/ geology/.

Pennsylvania Department of Environmental Protection, 2016a, PA Oil and Gas Mapping: Office of Oil and Gas Management, Interactive Map, accessed June 20, 2016, at http:// www.depgis.state.pa.us/PaOilAndGasMapping/.

Pennsylvania Department of Environmental Protection, 2016b, Recommended basic oil and gas pre-drill parameters: Commonwealth of Pennsylvania, Department of Environmental Protection, Fact Sheet 8000-FS-DEP4300 rev. 4/2016, accessed December 19, 2016, at http://www.elibrary. dep.state.pa.us/dsweb/Get/Document-112316/8000-FSDEP4300.pdf.

Pennsylvania Department of Environmental Protection, 2017, eMapPA: Pennsylvania Department of Environmental Protection web page, accessed August 25, 2017, at http://www. depgis.state.pa.us/emappa/.

PRISM Climate Group, 2003, Precipitation normals 1971-2000: Oregon State University, accessed October 1, 2003, at http://prism.oregonstate.edu/normals/.

Risser, D.W., Conger, R.W., Ulrich, J.E., and Asmussen, M.P., 2005, Estimates of ground-water recharge based on streamflow-hydrograph methods-Pennsylvania: U.S. Geological Survey Open-File Report 2005-1333, 30 p.

Rowan, E.L., Engle, M.A., Kirby, C.S., and Kraemer, T.F., 2011, Radium content of oil- and gas-field produced waters in the northern Appalachian Basin (USA) - Summary and discussion of data: U.S. Geological Survey Scientific Investigations Report 2011-5135, 31 p.

Sevon, W.D., comp., 2000, Physiographic provinces of Pennsylvania: Pennsylvania Geological Survey, 4th series, Map 13, scale 1:2,000,000.
Sevon, W.D., and Braun, D.D., 2000, Glacial deposits of Pennsylvania: Pennsylvania Geological Survey, 4th series, Map 59, scale 1:2,000,000.

Spotts, Stevens, McCoy, 2009, Williamsport Municipal Water Authority Source Water Protection Plan, November 2009: Report for Williamsport Municipal Water Authority, PWSID \#4410173, 45 p.

Toccalino, P.L., Norman, J.E., Booth, N.L., Thompson, J.L., and Zogorski, J.S., 2012, Health-based screening levels for evaluating water-quality data: U.S. Geological Survey web page, accessed July 1, 2016, at http://water.usgs.gov/nawqa/ HBSL/.

U.S. Census Bureau, 2010, QuickFacts, Williamsport city, Pennsylvania 2010 Census: U.S. Census Bureau web page, accessed July 5, 2016, at http://www.census.gov/quickfacts/ table/PST045215/4285312.

U.S. Environmental Protection Agency, 2016, Drinking water contaminants - Standards and regulations: U.S. Environmental Protection Agency web page, accessed July 6, 2016, at https://www.epa.gov/dwstandardsregulations.

U.S. Geological Survey, variously dated, National field manual for the collection of water-quality data: U.S. Geological Survey Techniques of Water-Resources Investigations, book 9, chapters A1-A9, accessed April 4, 2016, at http:// pubs.water.usgs.gov/twri9A.

U.S. Geological Survey, 2016a, The National Hydrography Dataset: U.S. Geological Survey database, accessed June 22, 2016, at http://nhd.usgs.gov/index.html.

U.S. Geological Survey, 2016b, Standard Reference Sample Project: Bureau of Quality Systems, accessed June 22, 2016, at https://bqs.usgs.gov/srs/.

U.S. Geological Survey, 2017, USGS water data for the Nation: U.S. Geological Survey National Water Information System database, accessed December 7, 2017, at https://doi. org/10.5066/F7P55KJN.

Whittemore, D.O., 2007, Fate and identification of oil-brine contamination in different hydrogeologic settings: Applied Geochemistry, v. 22, p. 2099-2114. 


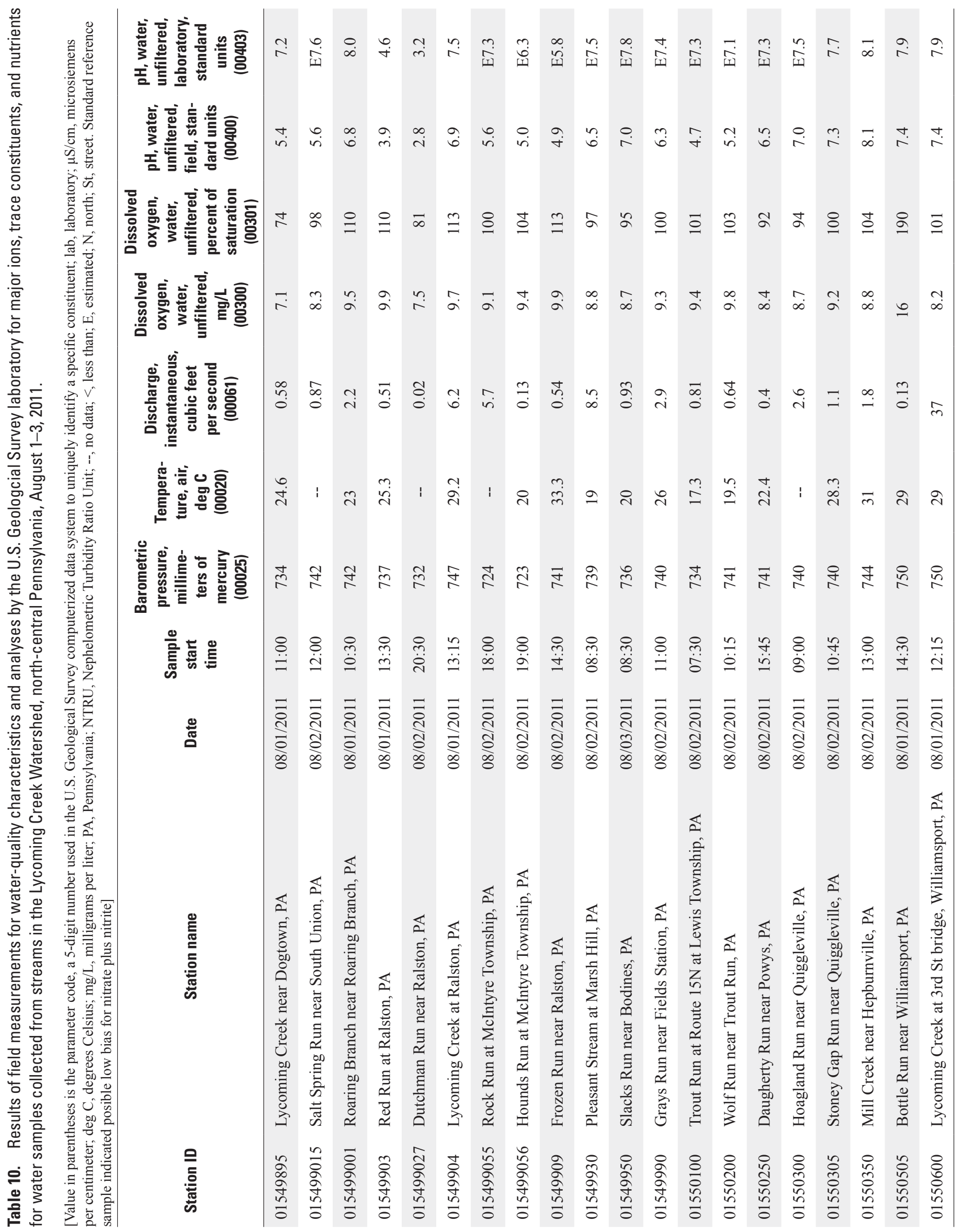


글

垔

(9)

के बृ

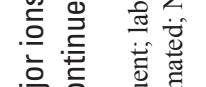

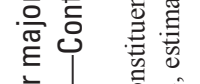

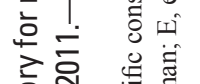
$\begin{array}{ll}0 & 0 \\ 0 & 0 \\ 0 & 0 \\ 0 & 0 \\ 0 & 0\end{array}$ 范苟

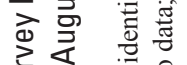
क त्

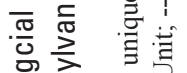

응 올 울

जั एँ

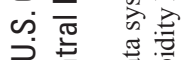

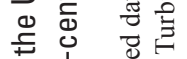

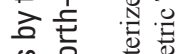

\&

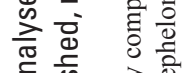

त के बें

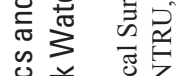

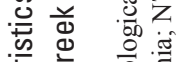

氜

苋高 的帘

ปั

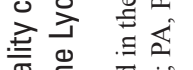

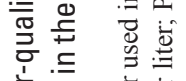

离

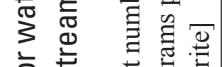

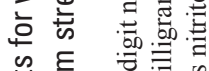

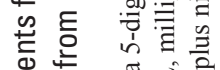

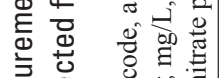

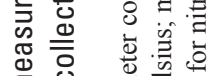

ڤ્

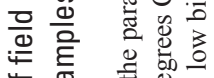

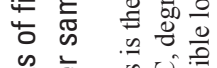

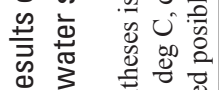

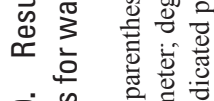

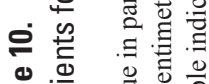

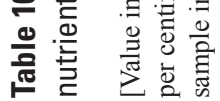

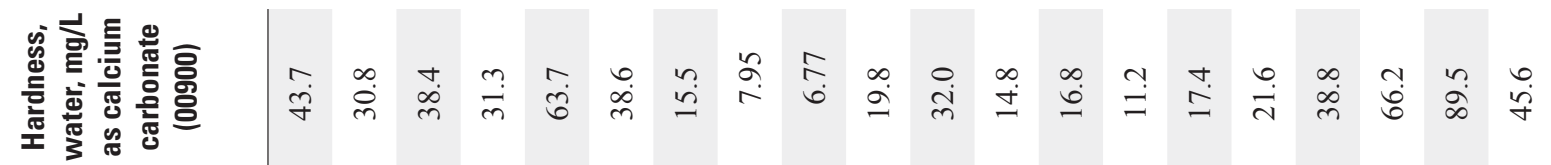

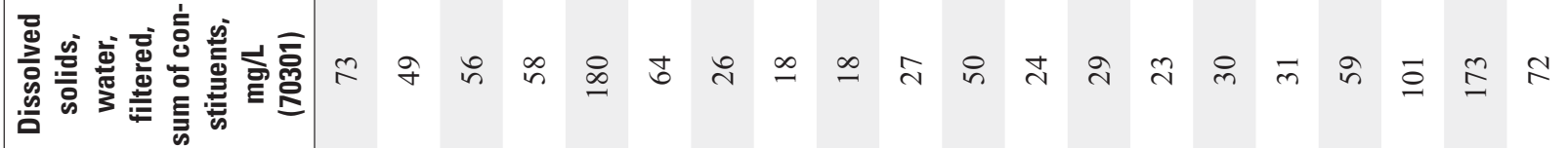

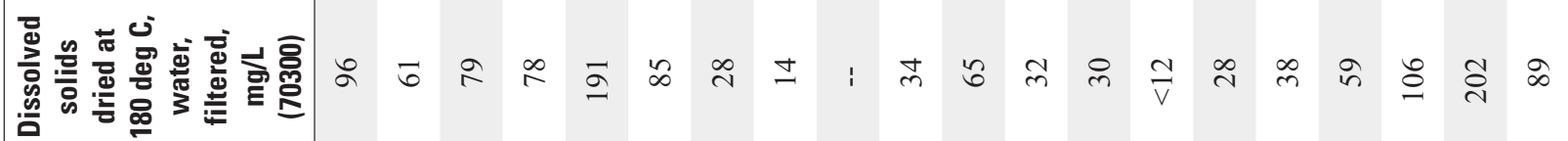

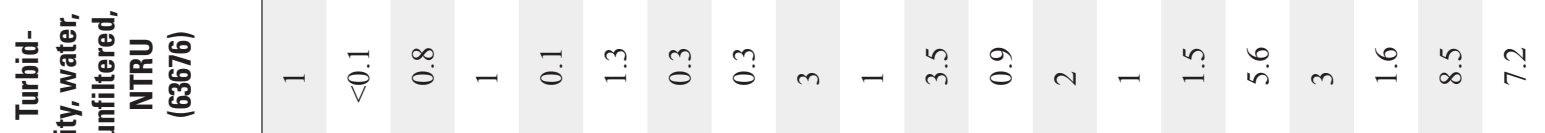

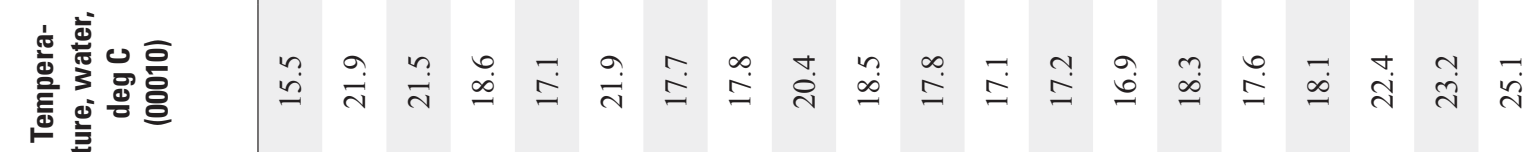

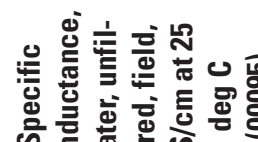

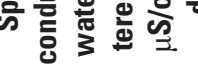

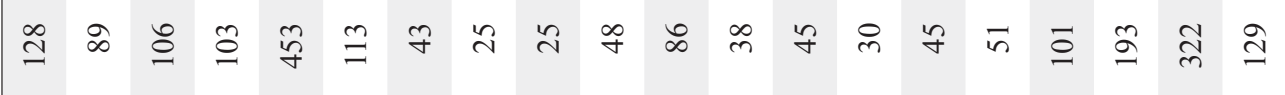
ن d 离言

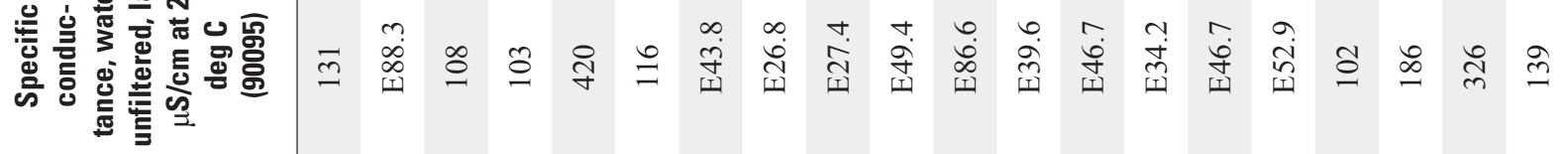

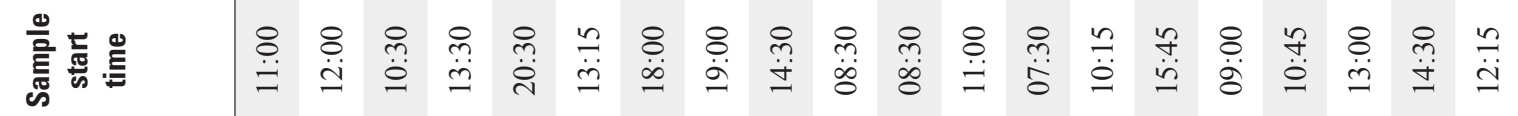

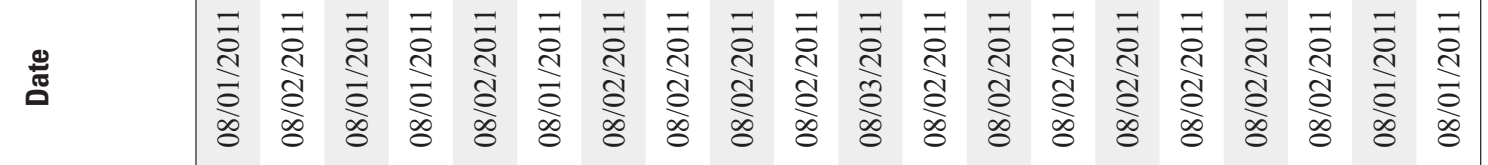

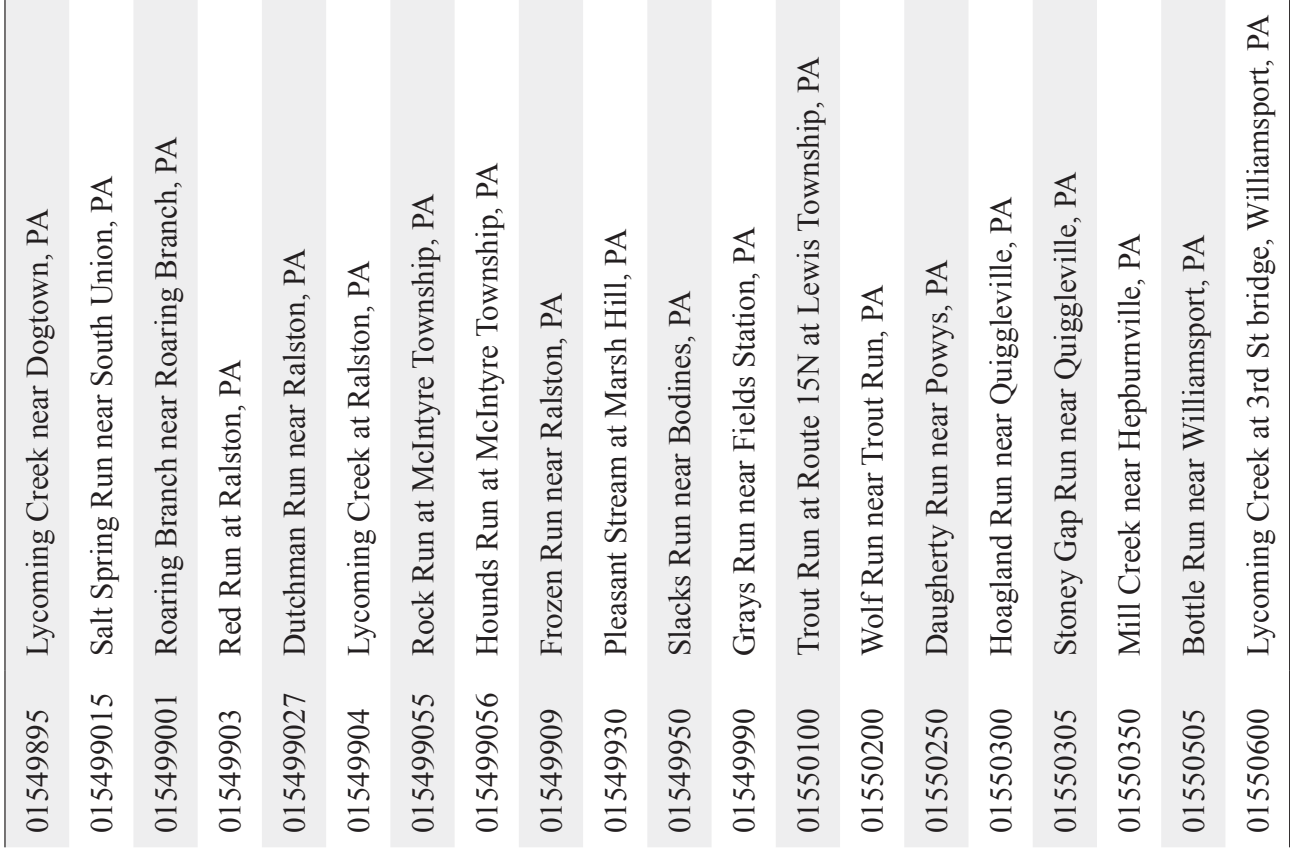




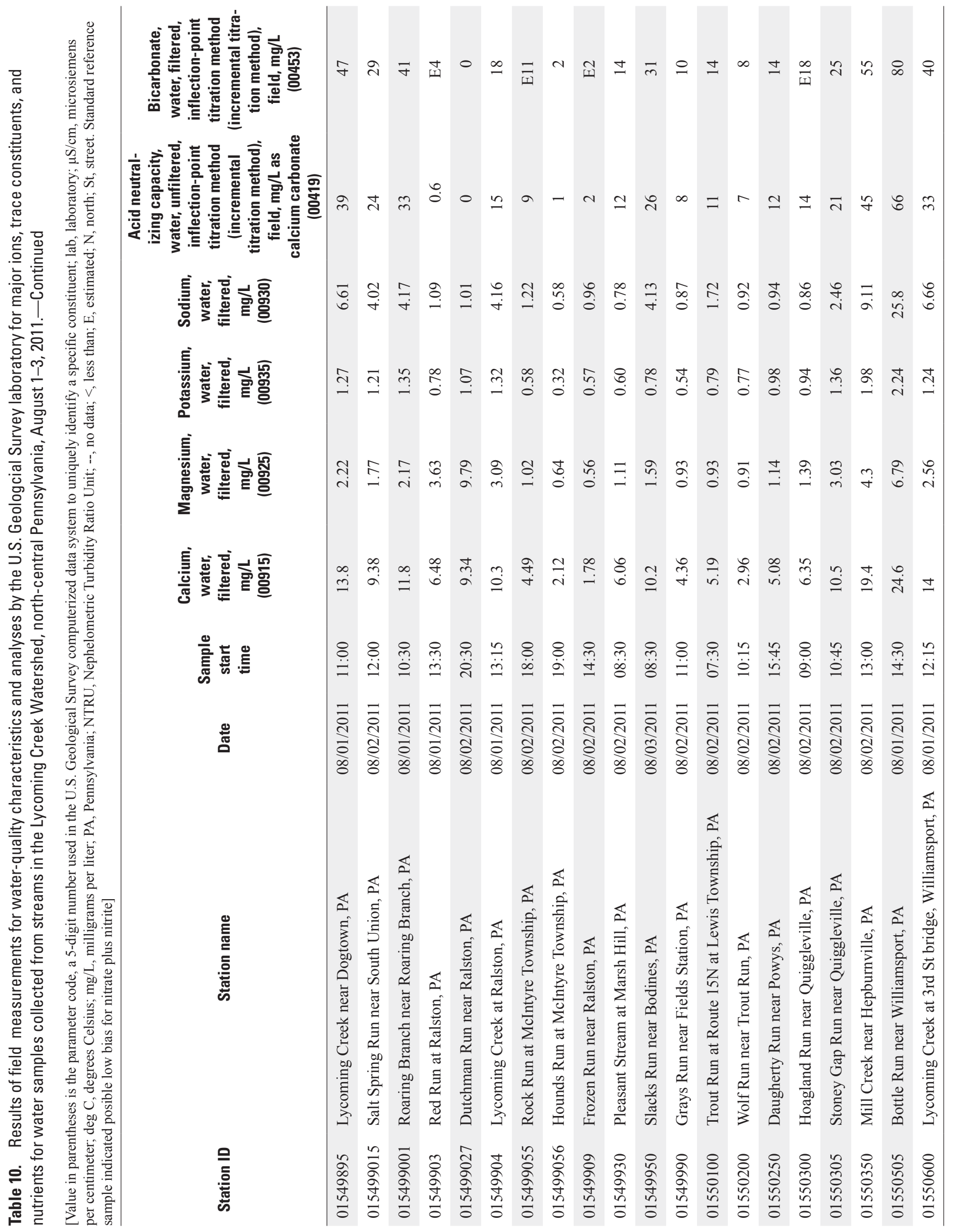




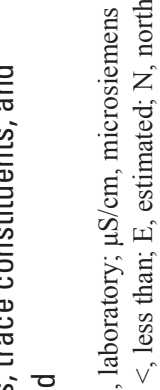

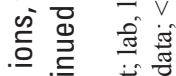

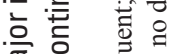

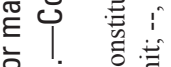

흐유.

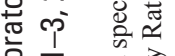

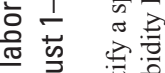

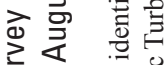

के $\frac{\pi}{\frac{\pi}{5}}$

可 爷

응 㝕

का ए

了焉

离 总

वे

券完 考

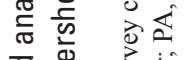

它焉离

号 焉

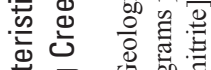

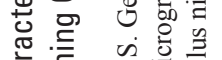

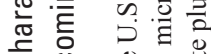

ป仓

夏导

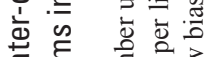

恣焉言言

京离

总

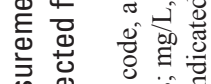

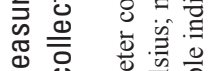

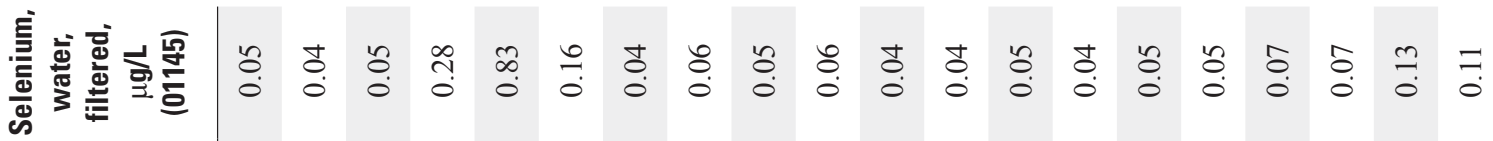

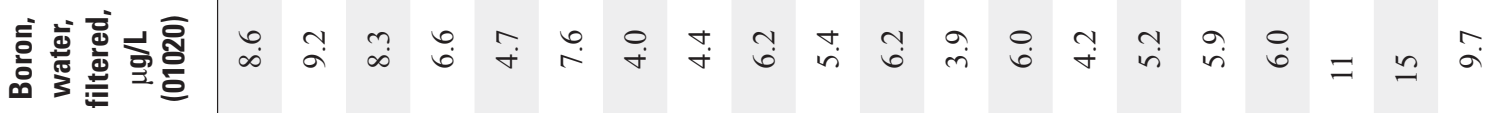

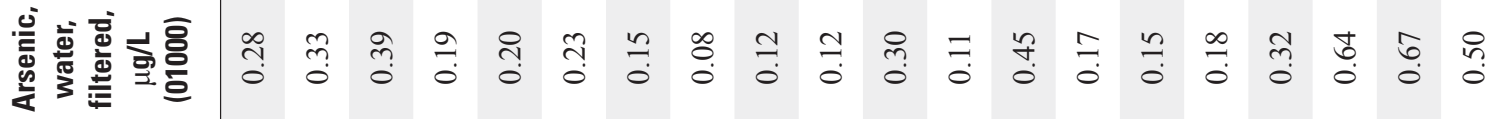

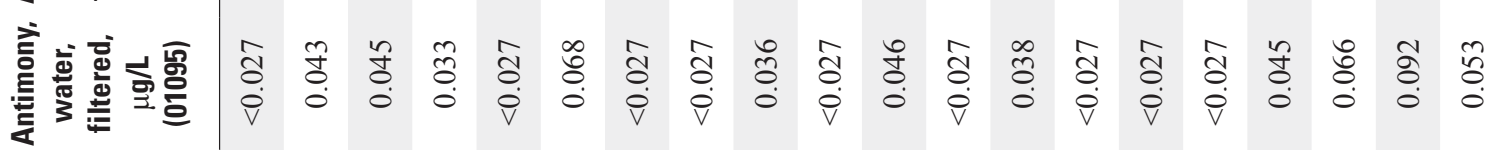

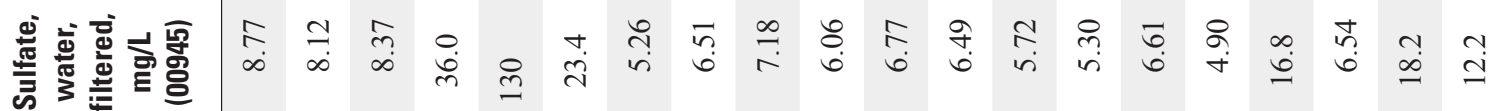

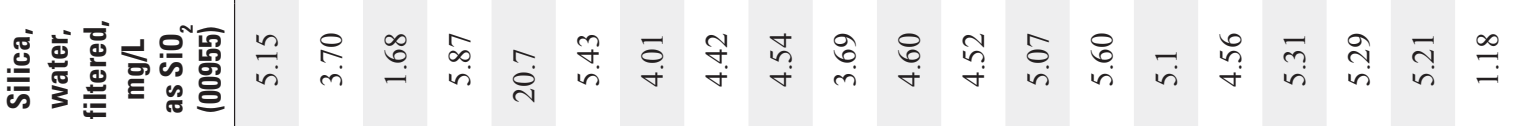

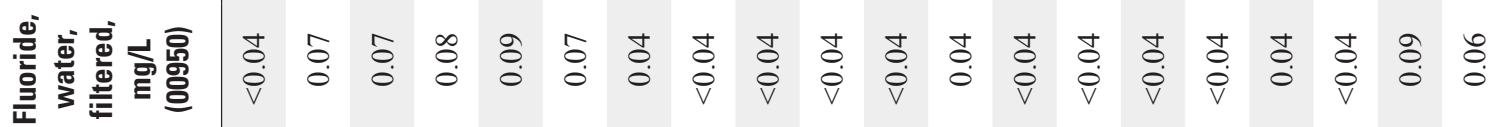

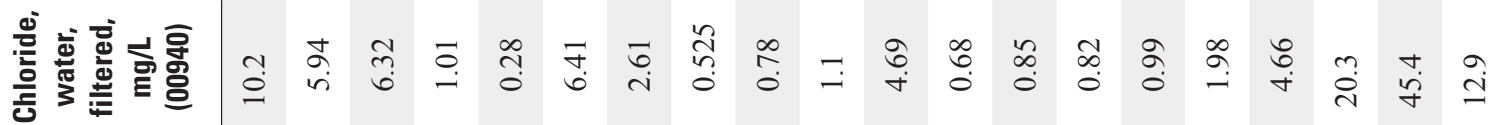

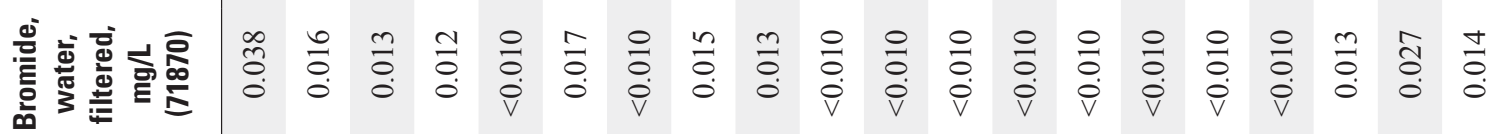

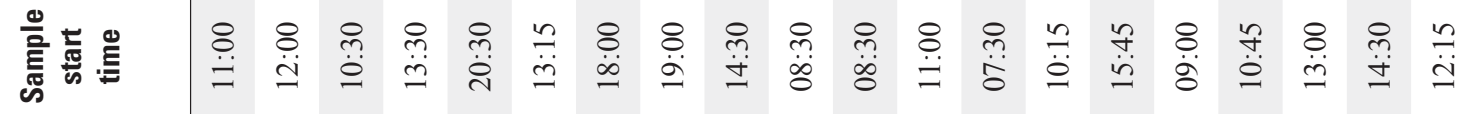

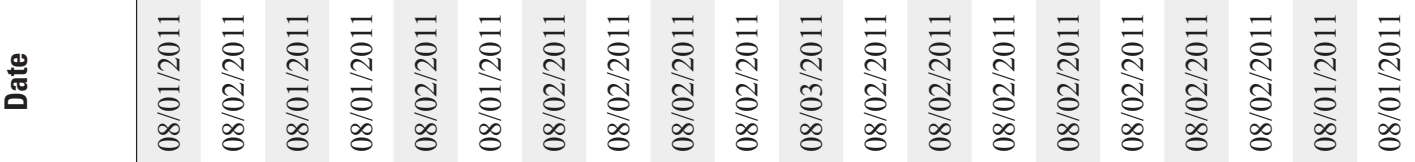

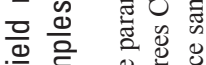
焉

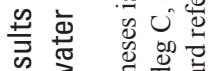

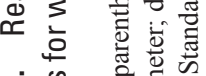

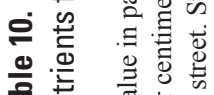

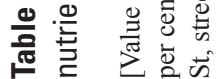

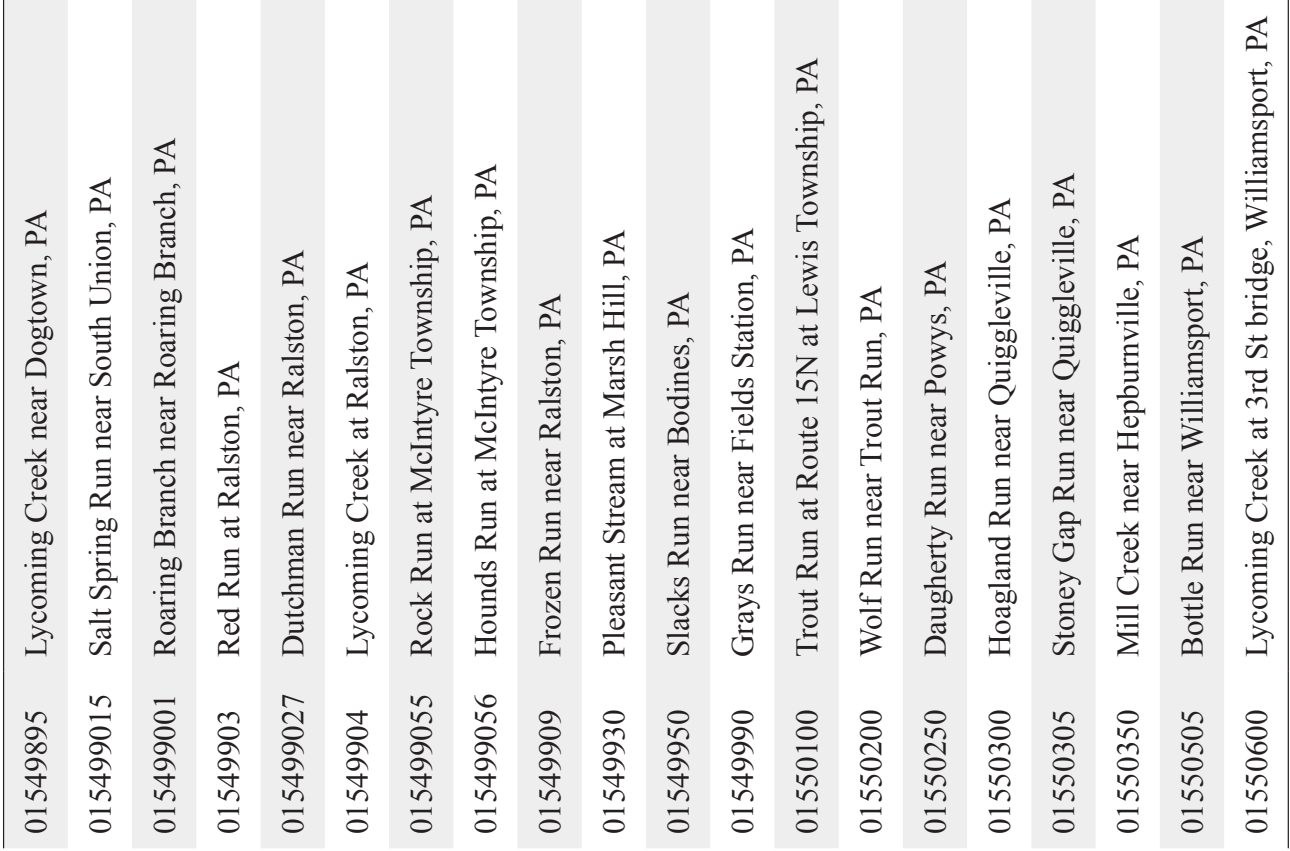




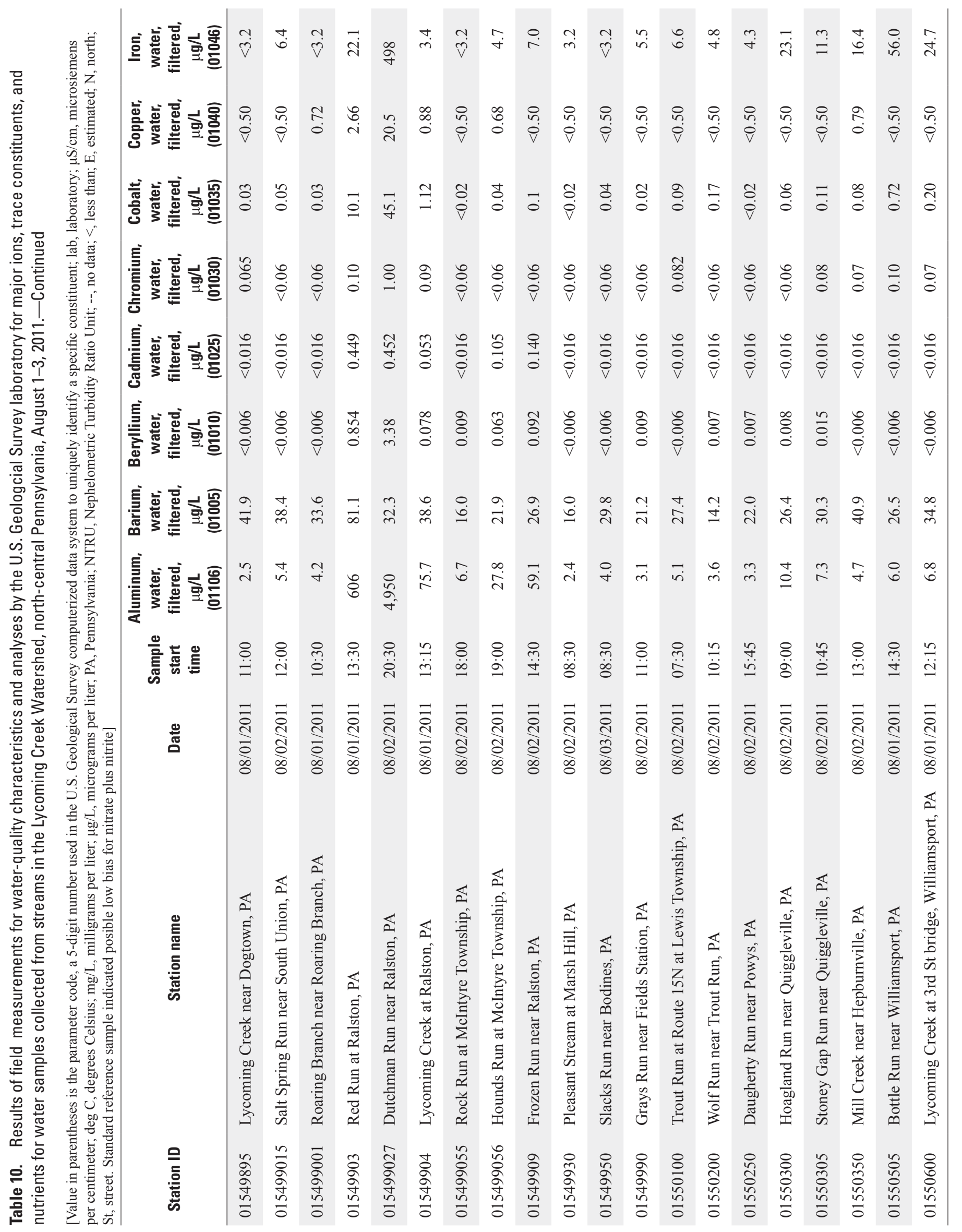




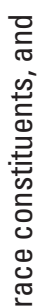

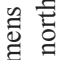

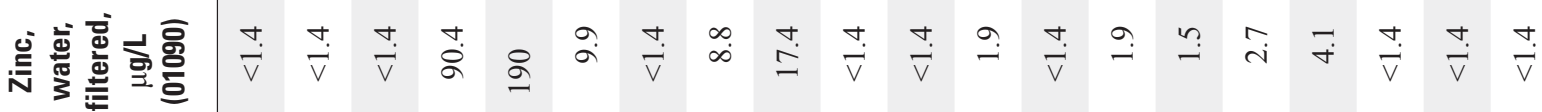

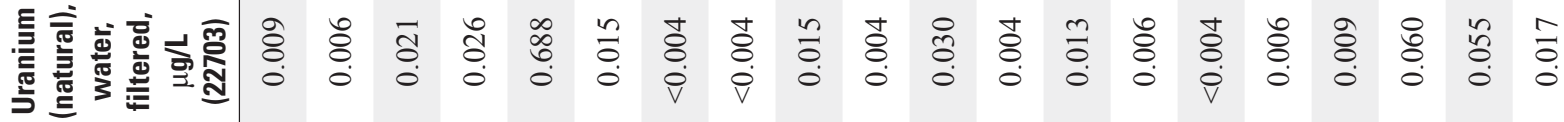
है

을

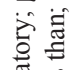

要

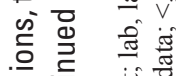

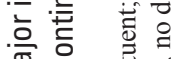

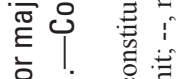

흔.

충

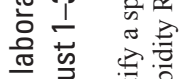

文宗曾

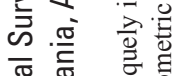

중

音

응 㝕 ?

心

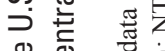

离 总

合至

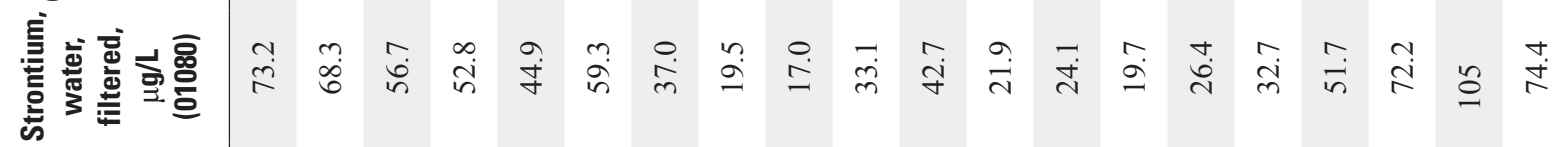

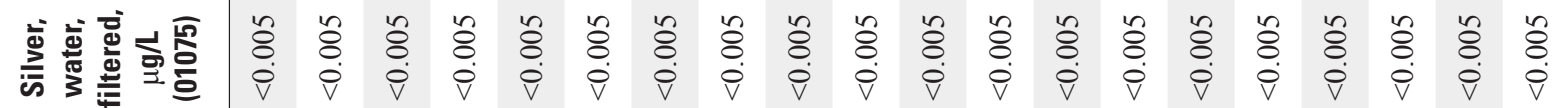

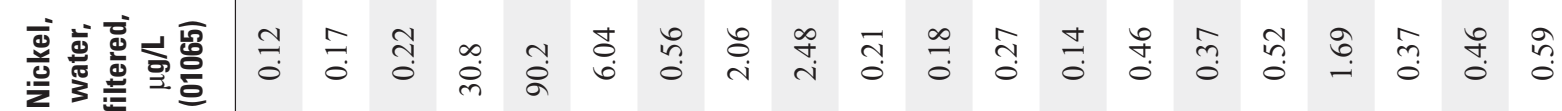

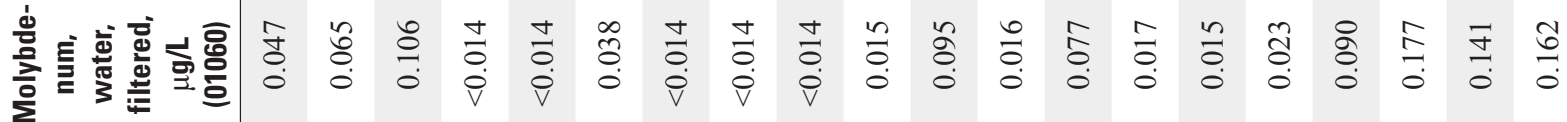

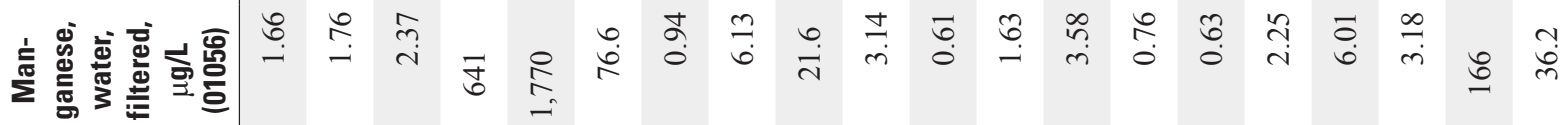

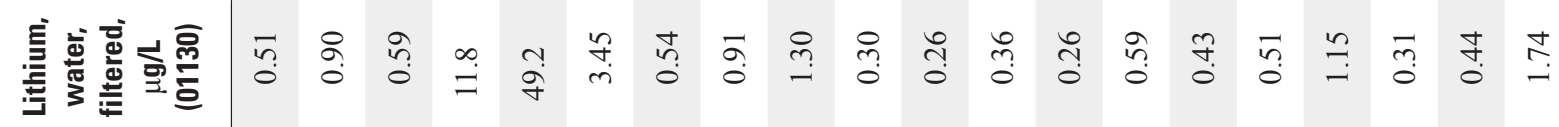

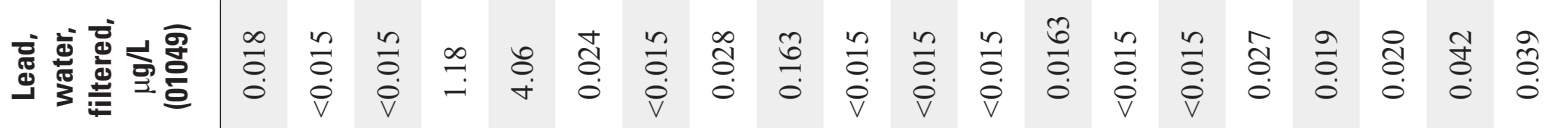

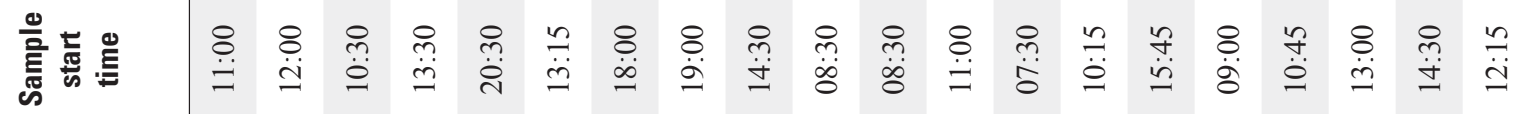

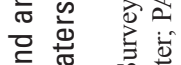
S) o

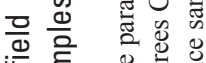
焉

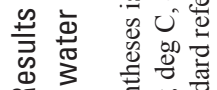

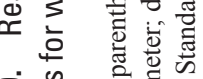

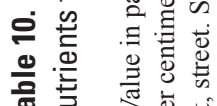

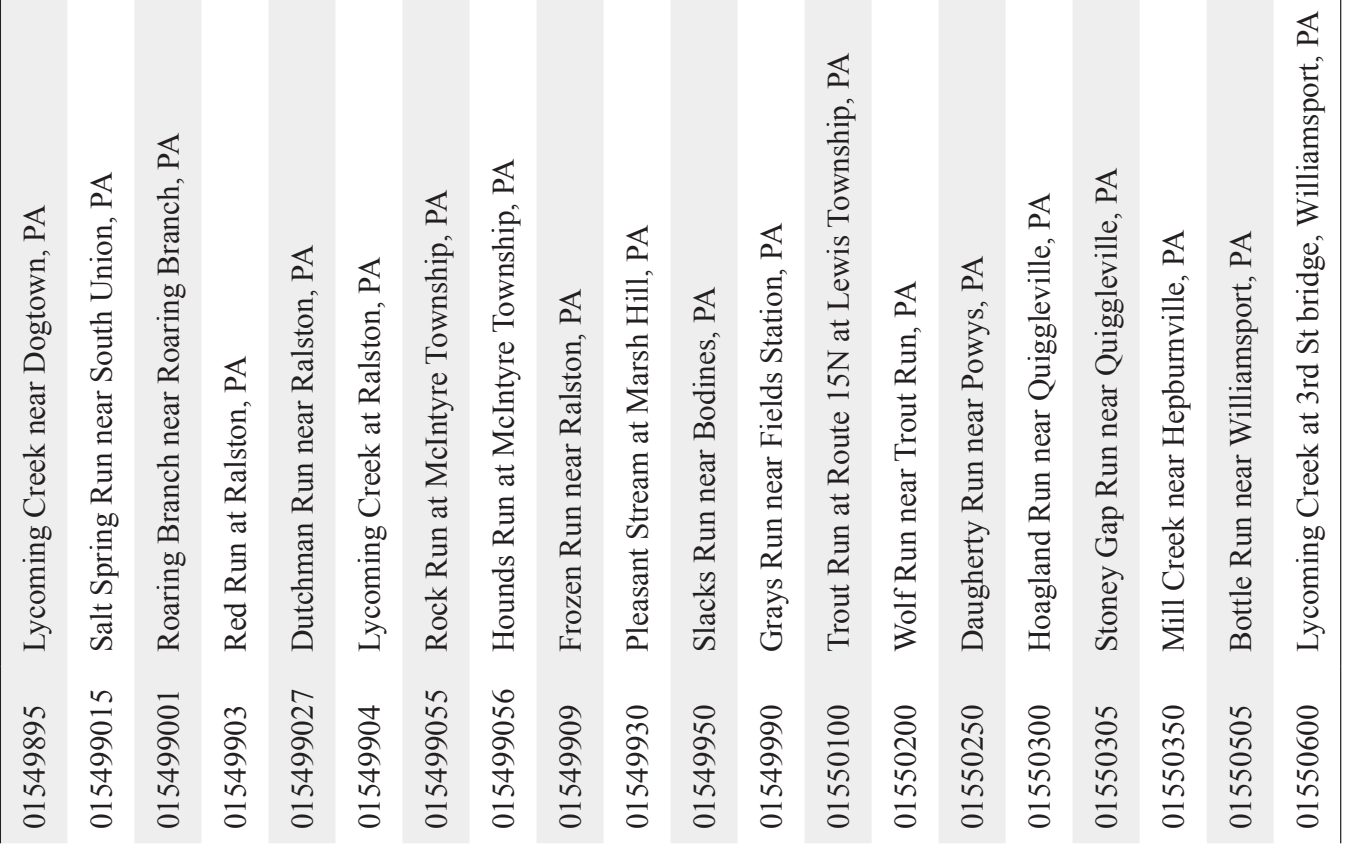




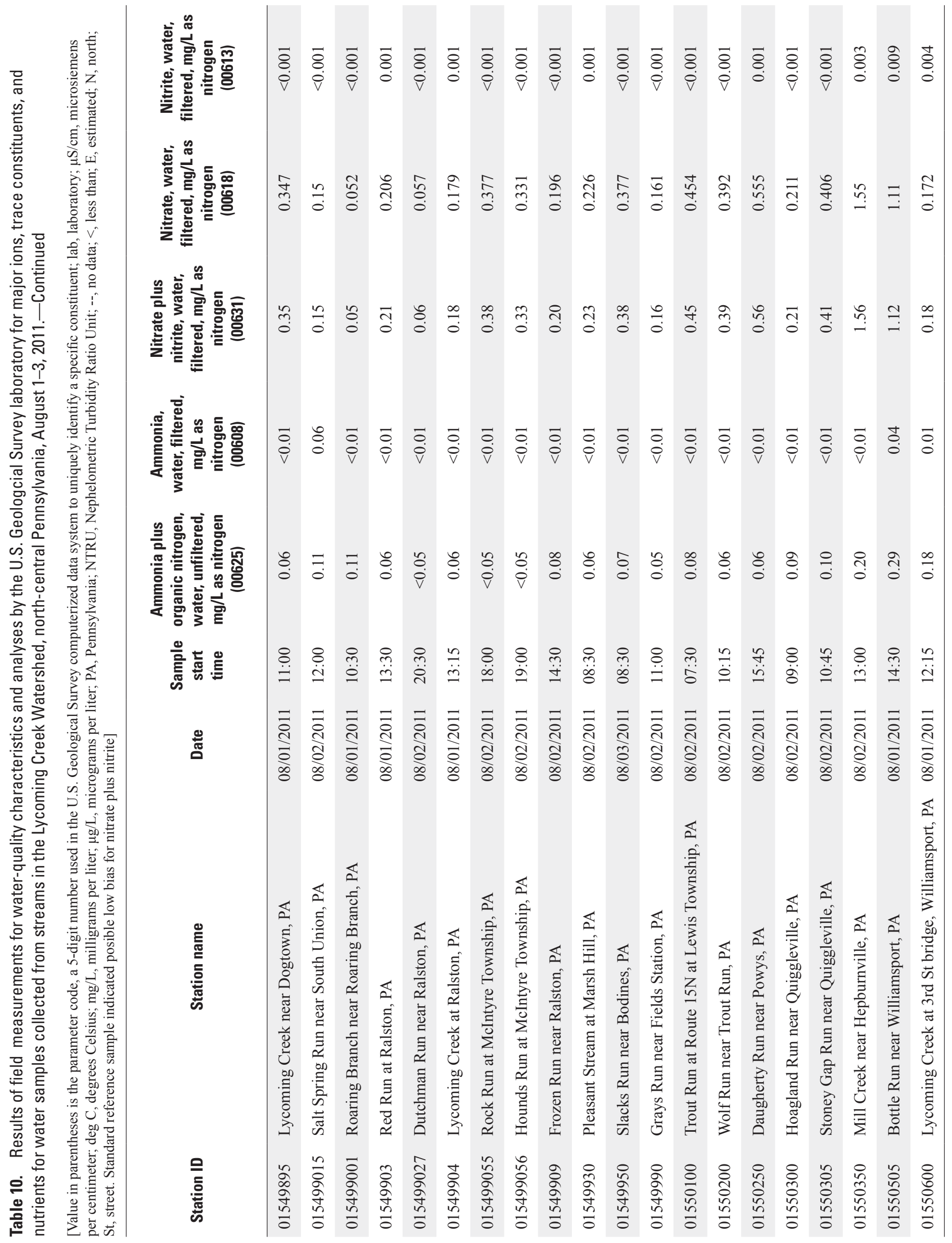




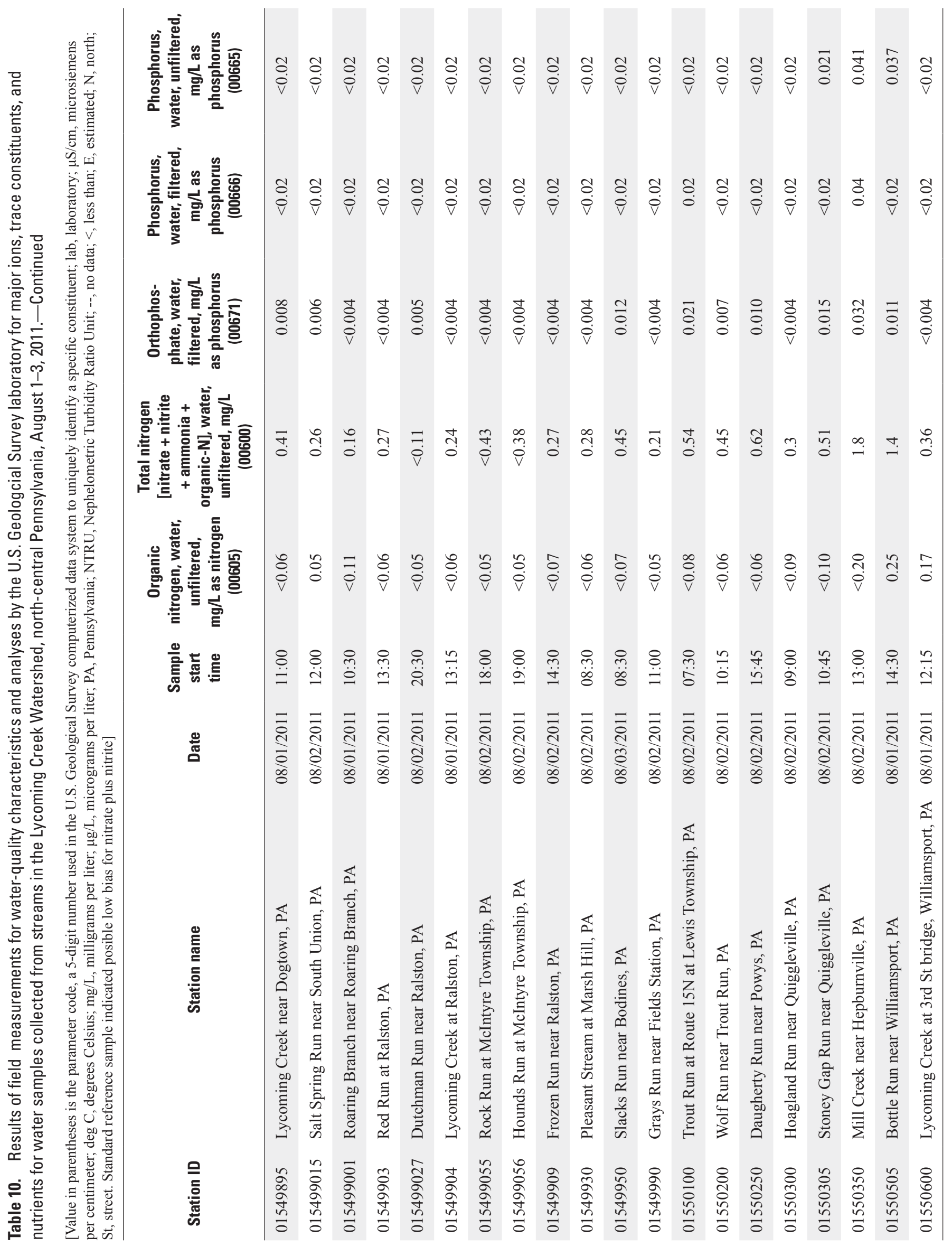


Table 11. Detailed radiochemical analytical results for water samples collected from streams in the Lycoming Creek watershed, northcentral Pennsylvania, August 1-3, 2011.

[Result, radiological concentration; CSU, combined standard uncertainty (1-sigma); ssLc, sample-specific critical level; 72-h, sample analyzed for concentration at approximately 72 hours after sample collection as referenced to a detector calibrated using ${ }^{230} \mathrm{Th}$ for gross alpha and ${ }^{137} \mathrm{Cs}$ for gross beta; 30 -d, sample used for the 72-hour analysis is counted a second time approximately 30 days after the initial count as referenced to a detector calibrated using ${ }^{230} \mathrm{Th}$ for gross alpha and ${ }^{137} \mathrm{Cs}$ for gross beta; $\mathrm{pCi} / \mathrm{L}$; picocuries per liter; PA, Pennsylvania; St, street; N, north]

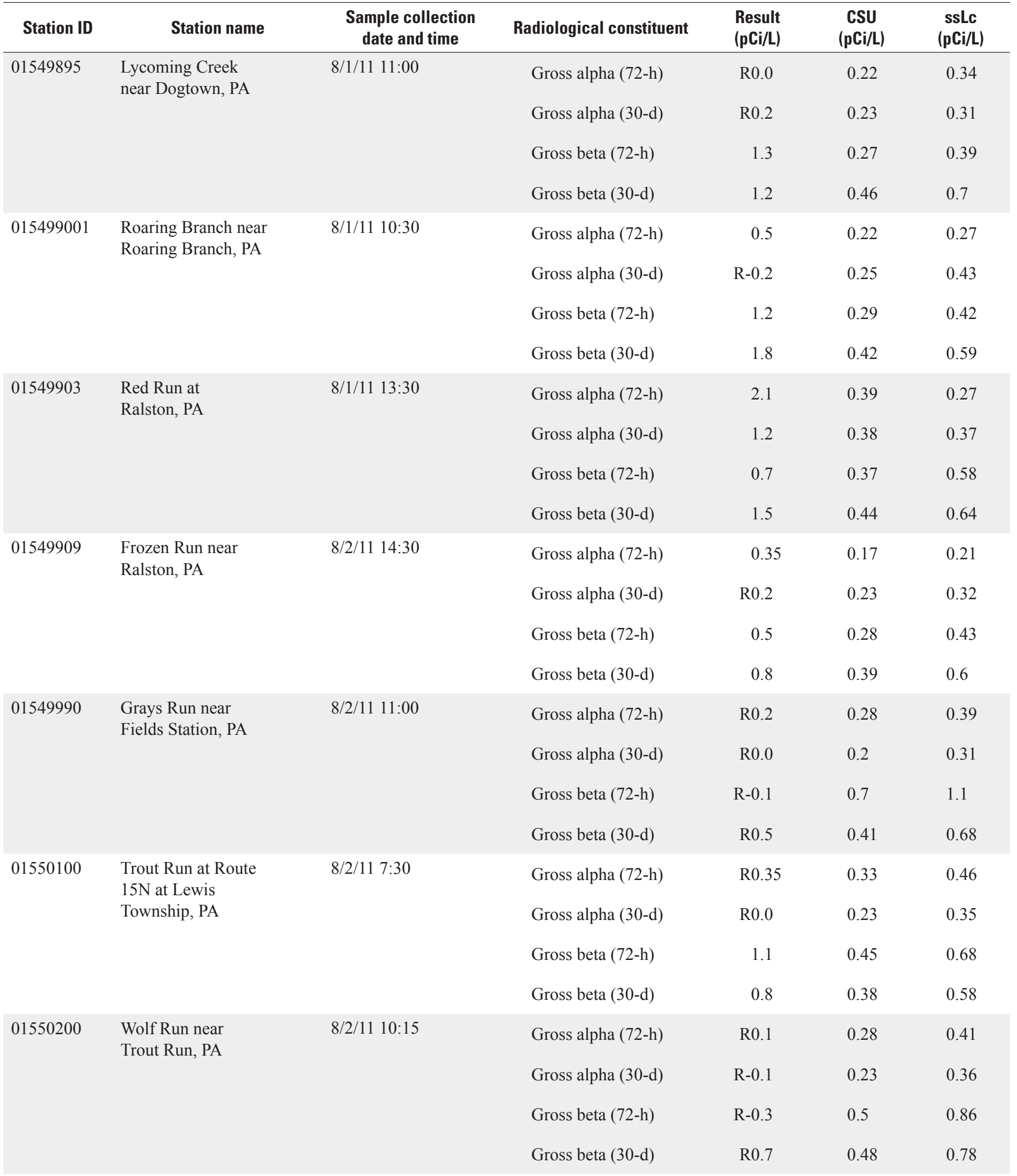


Table 11. Detailed radiochemical analytical results for water samples collected from streams in the Lycoming Creek watershed, northcentral Pennsylvania, August 1-3, 2011.-Continued

[Result, radiological concentration; CSU, combined standard uncertainty (1-sigma); ssLc, sample-specific critical level; 72-h, sample analyzed for concentration at approximately 72 hours after sample collection as referenced to a detector calibrated using ${ }^{230} \mathrm{Th}$ for gross alpha and ${ }^{137} \mathrm{Cs}$ for gross beta; 30 -d, sample used for the 72-hour analysis is counted a second time approximately 30 days after the initial count as referenced to a detector calibrated using ${ }^{230} \mathrm{Th}$ for gross alpha and ${ }^{137} \mathrm{Cs}$ for gross beta; pCi/L; picocuries per liter; PA, Pennsylvania; St, street; N, north]

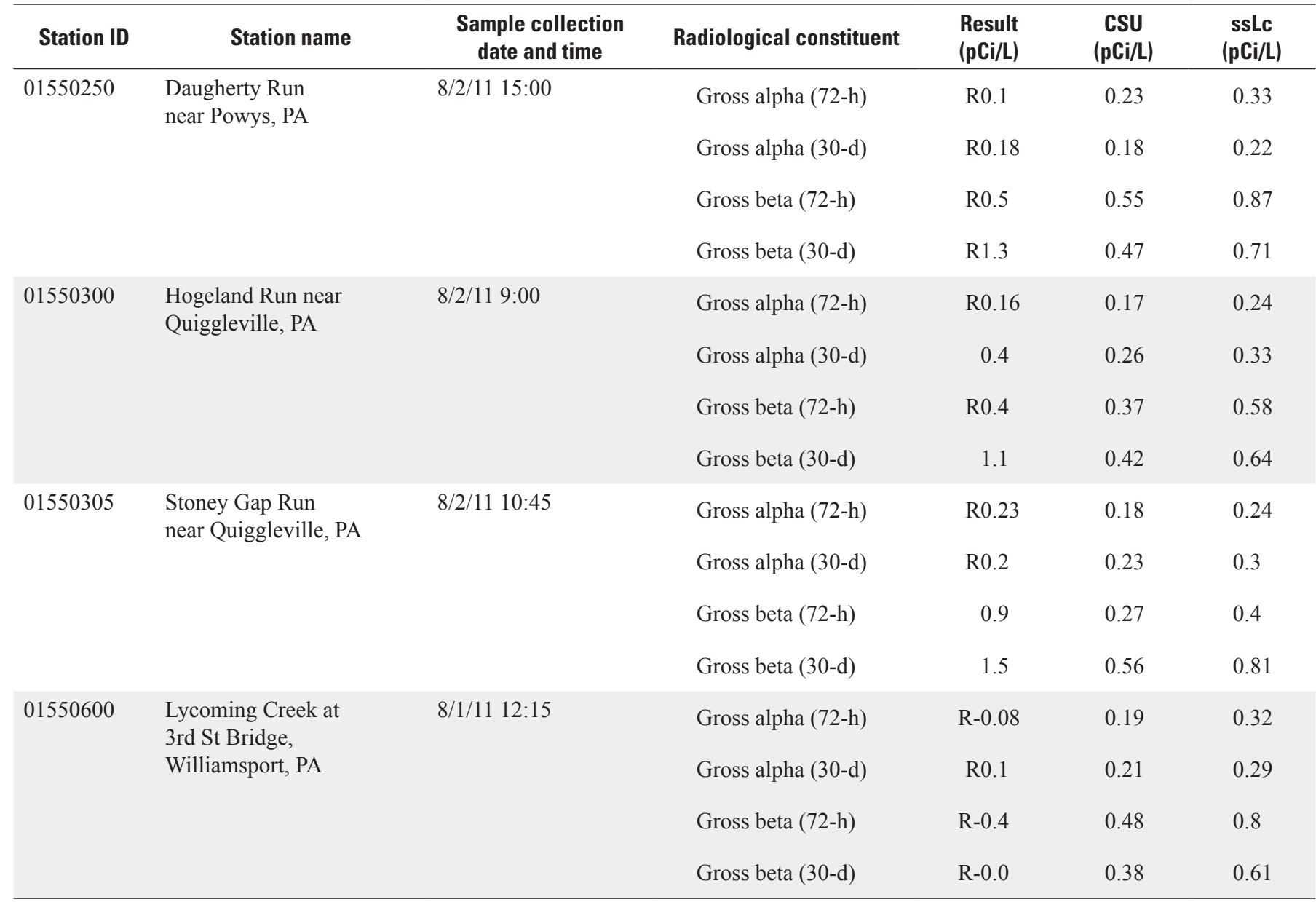




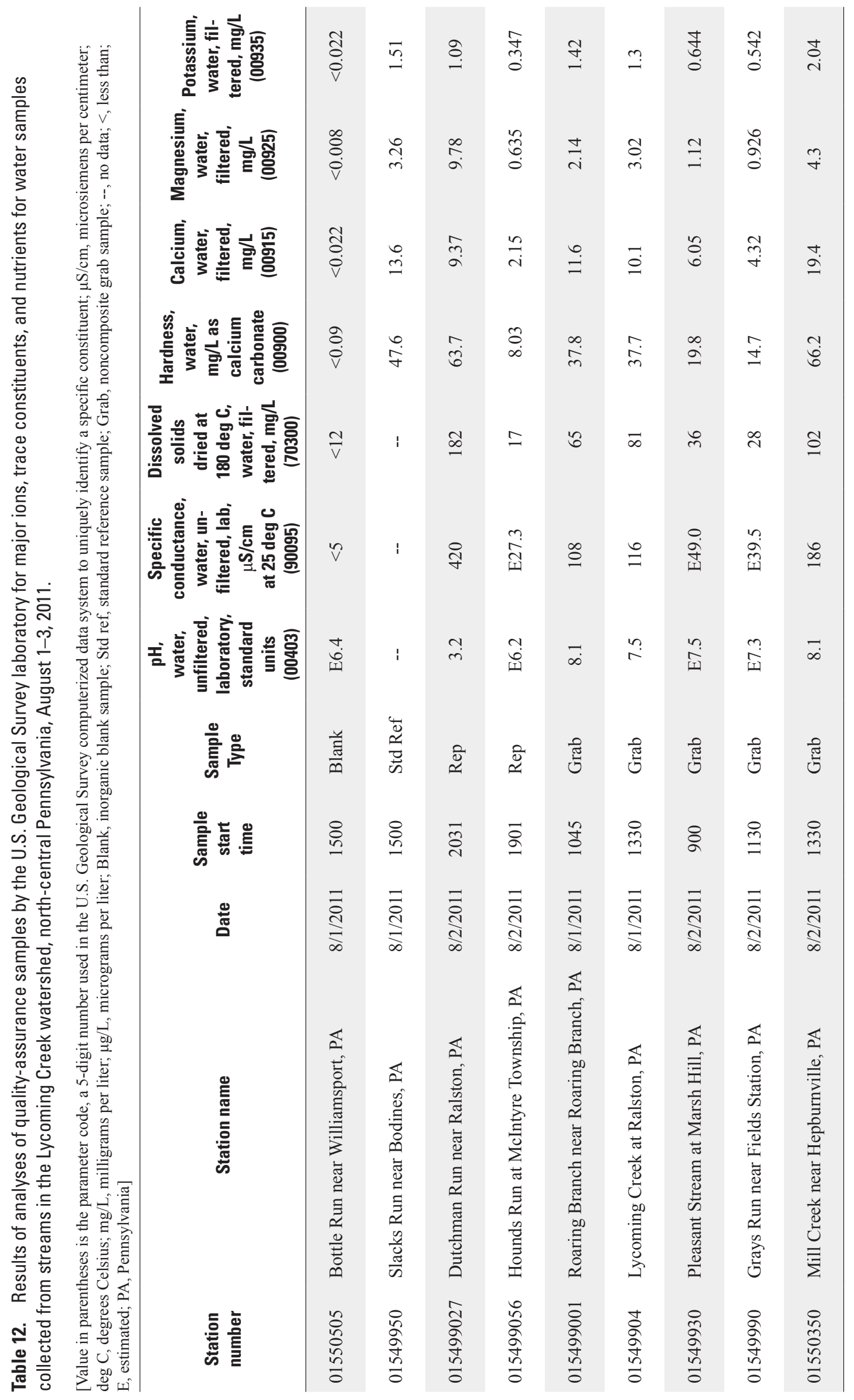




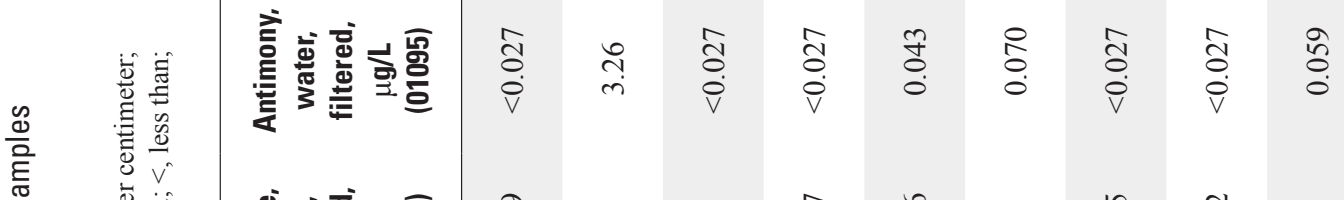
离

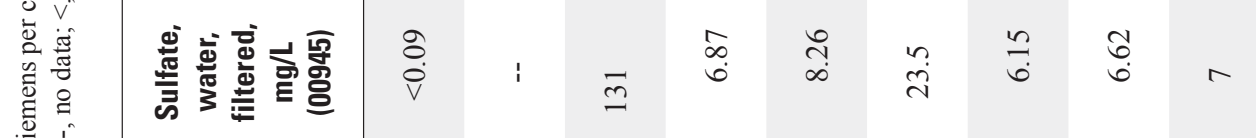
要

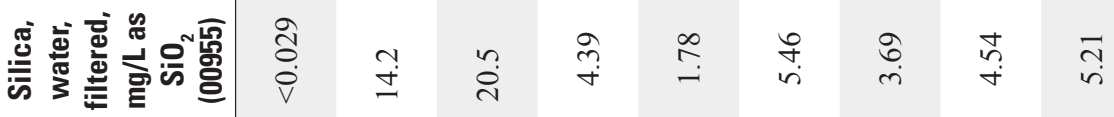

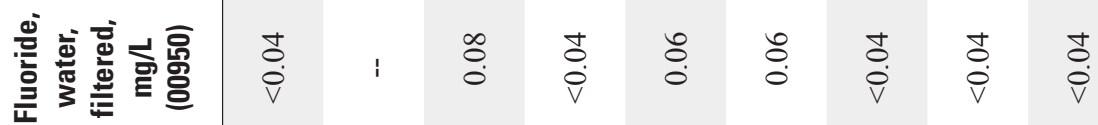

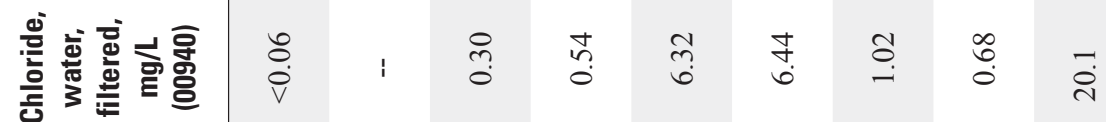

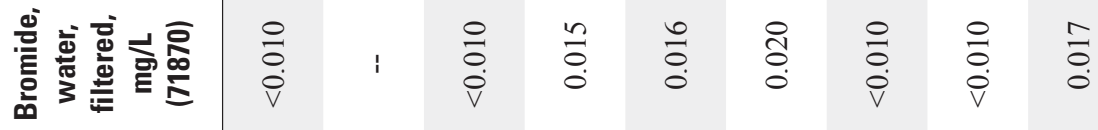

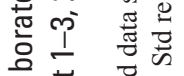

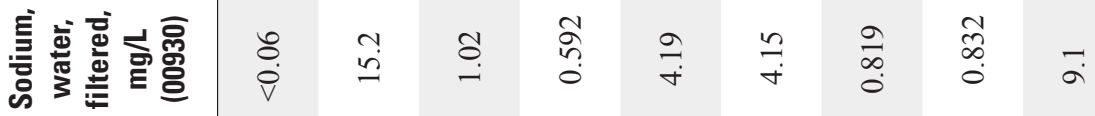

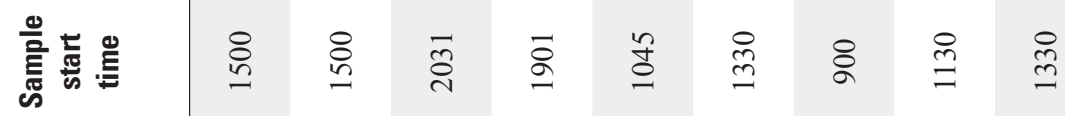

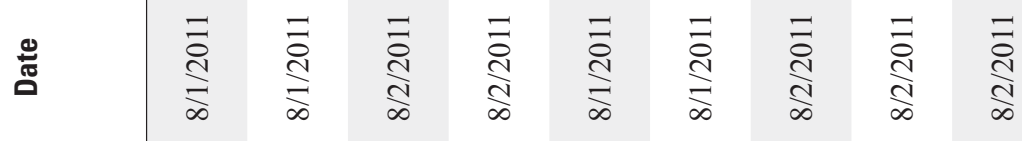

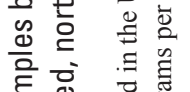




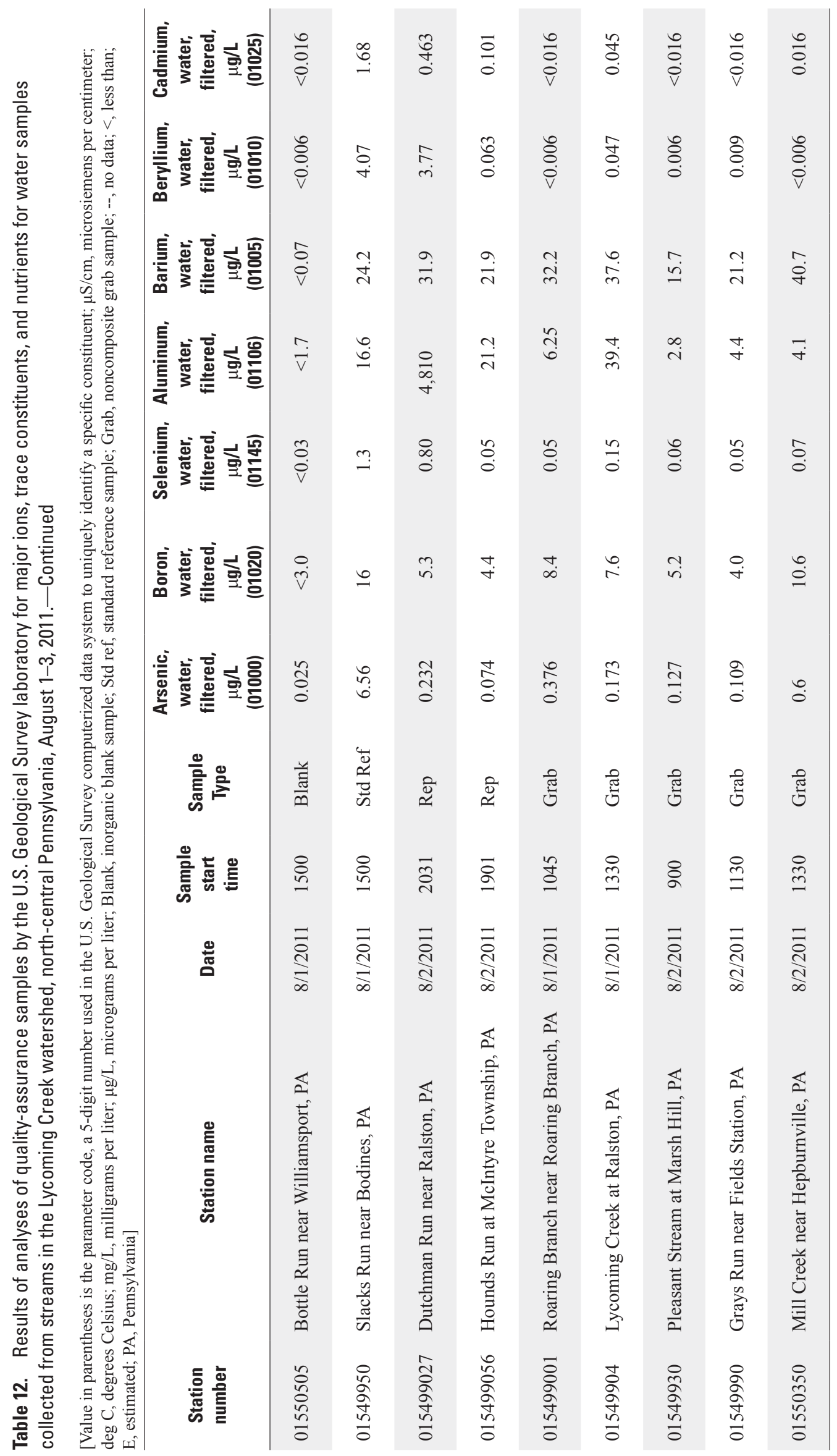




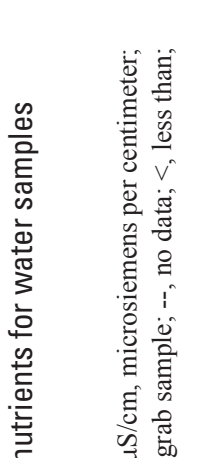

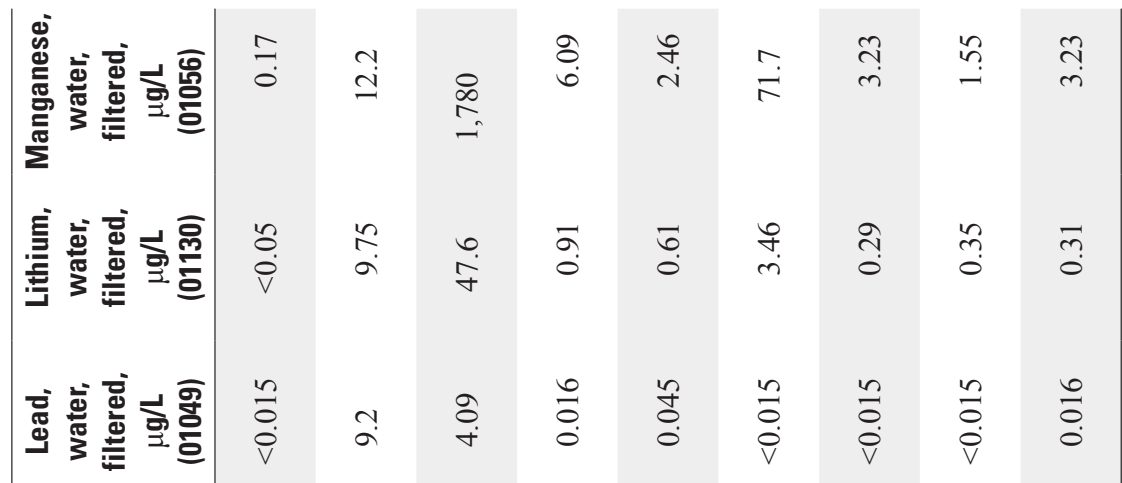

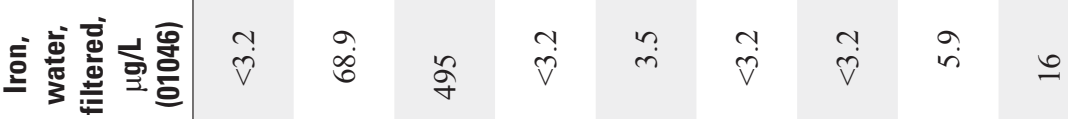

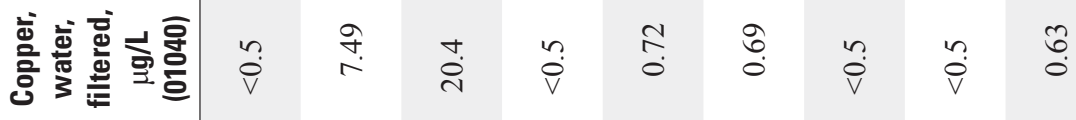

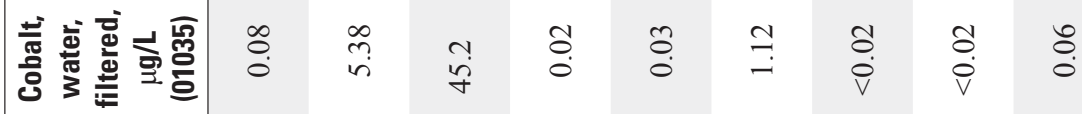

Eิ잉.

춤

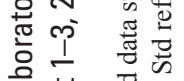

要劳

总亭

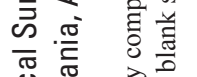

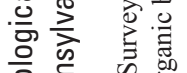

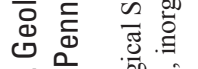

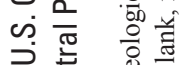

ه 잉

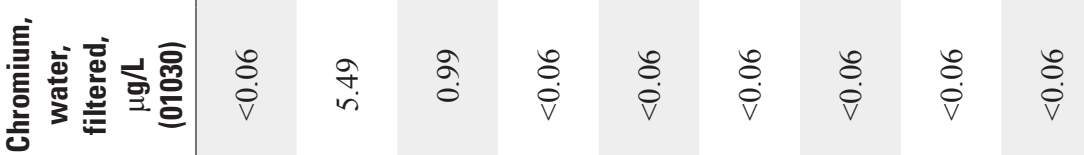

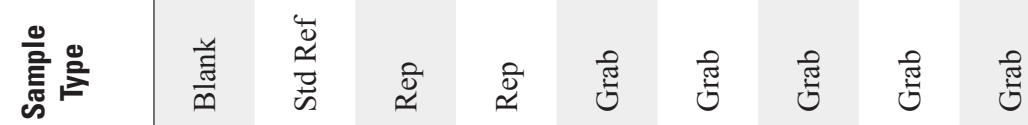

产志兽

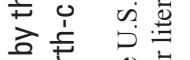

梀 흘

言空记

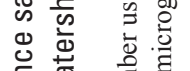

谣

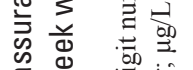

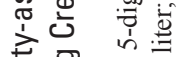

言高

to

边

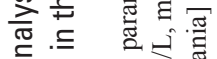

元夗

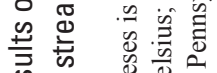

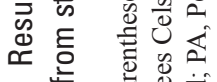

늘

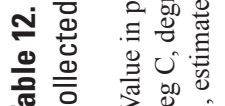

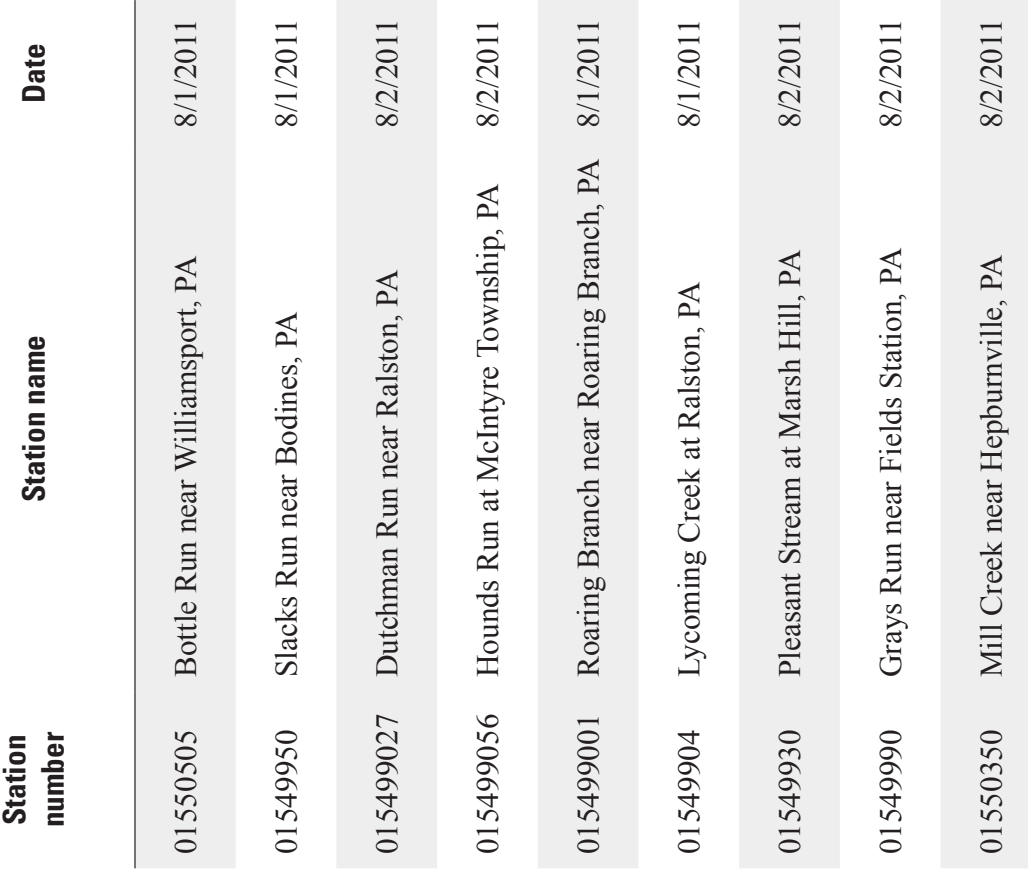




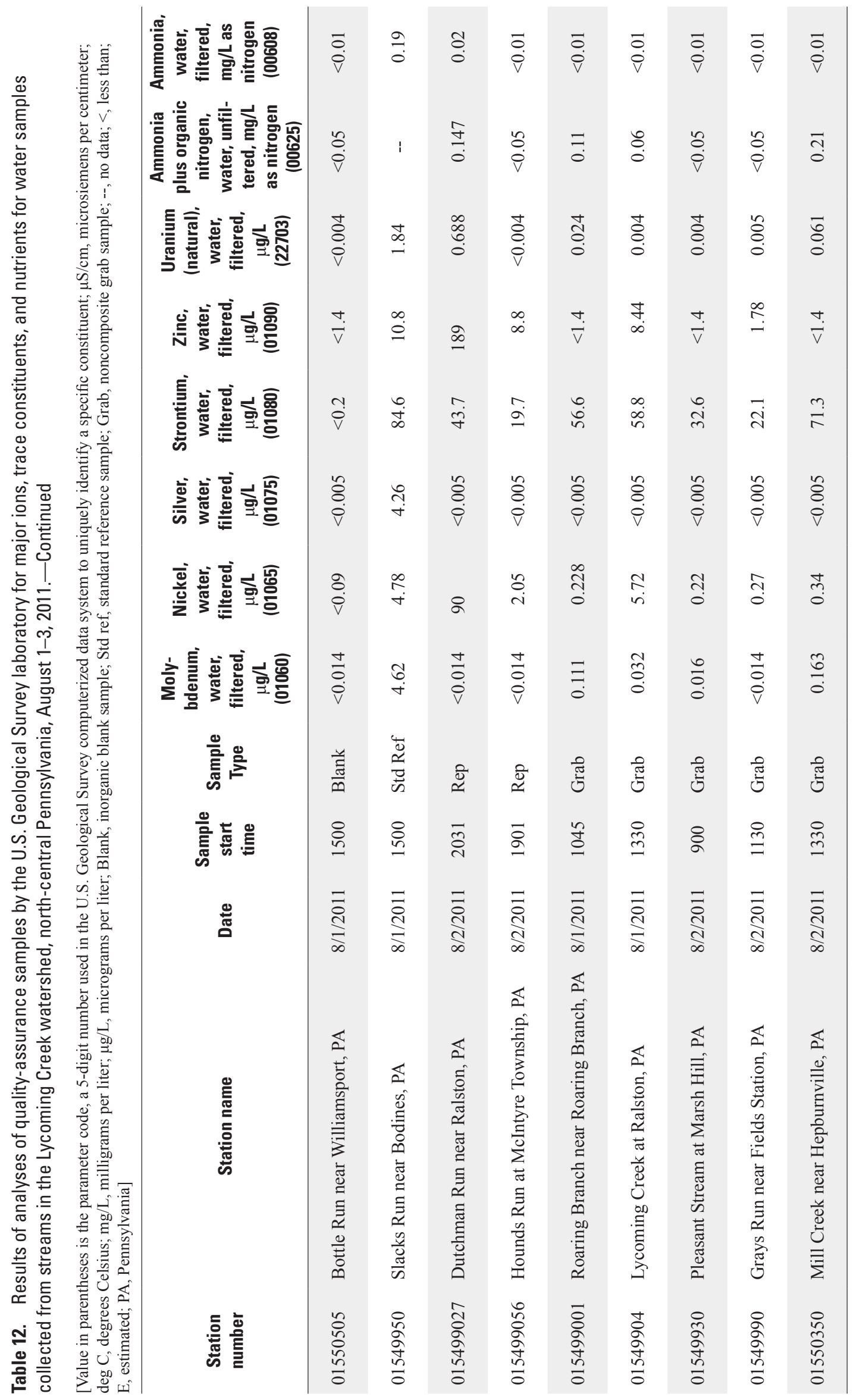




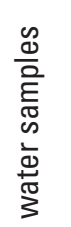

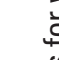

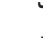

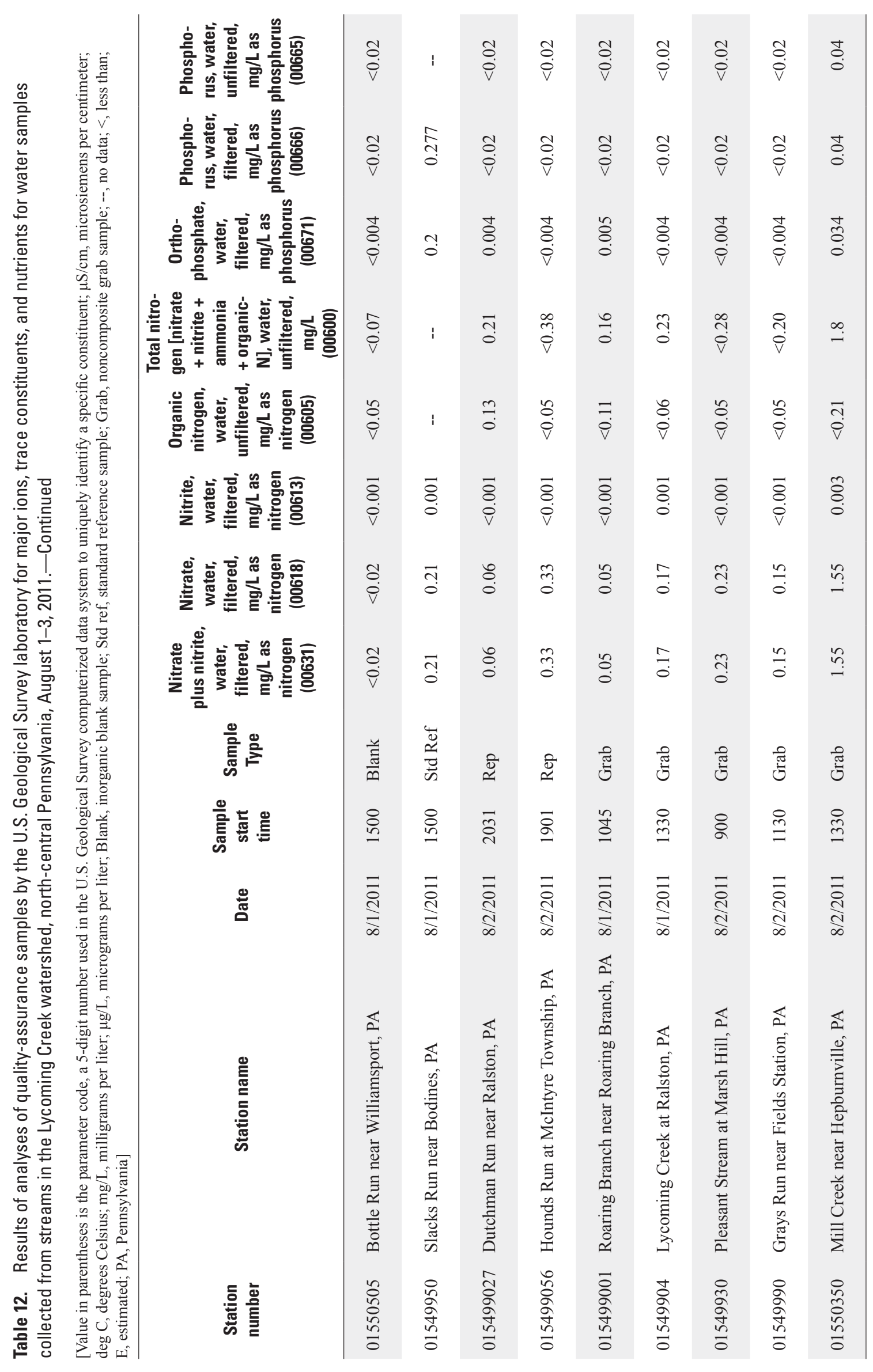




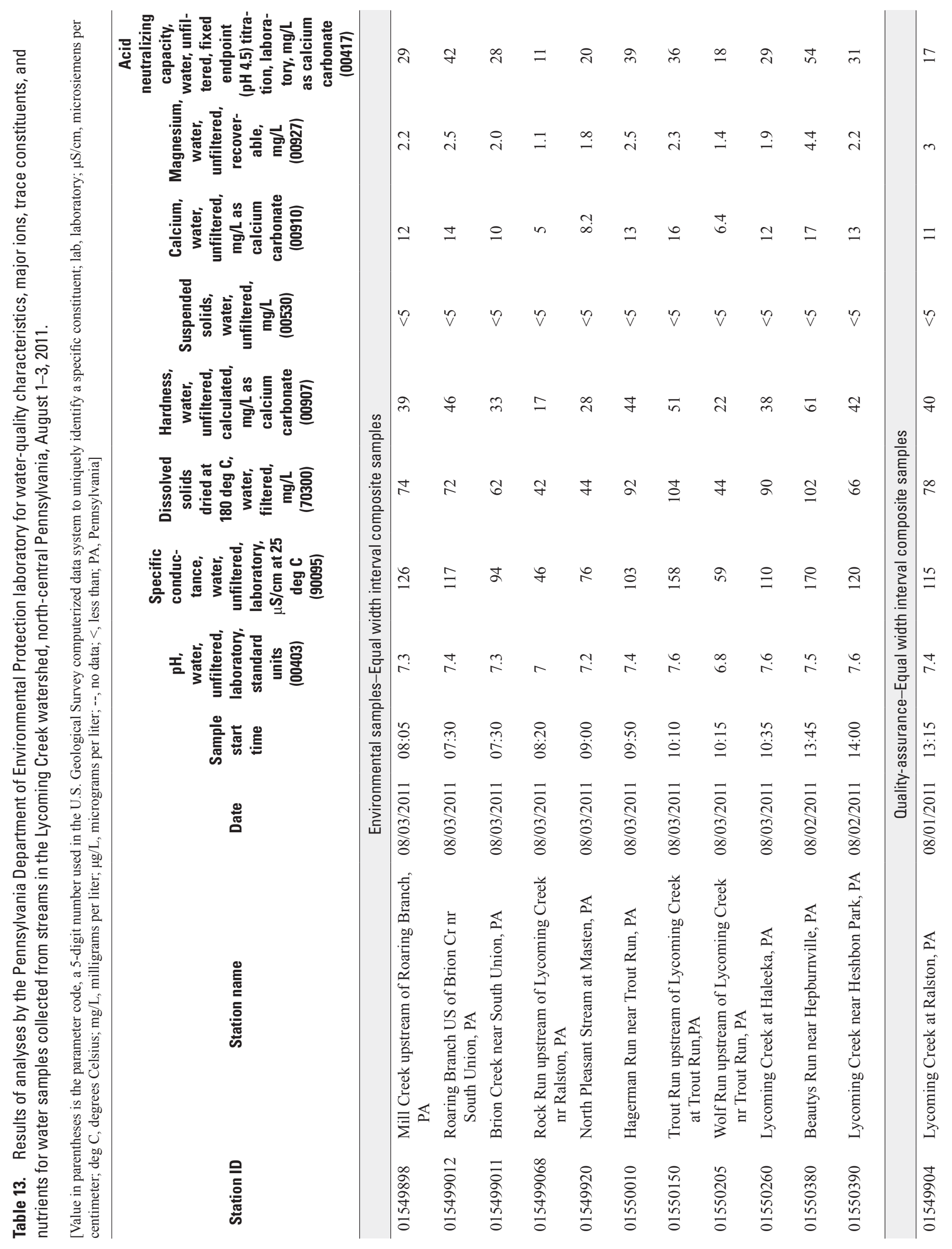




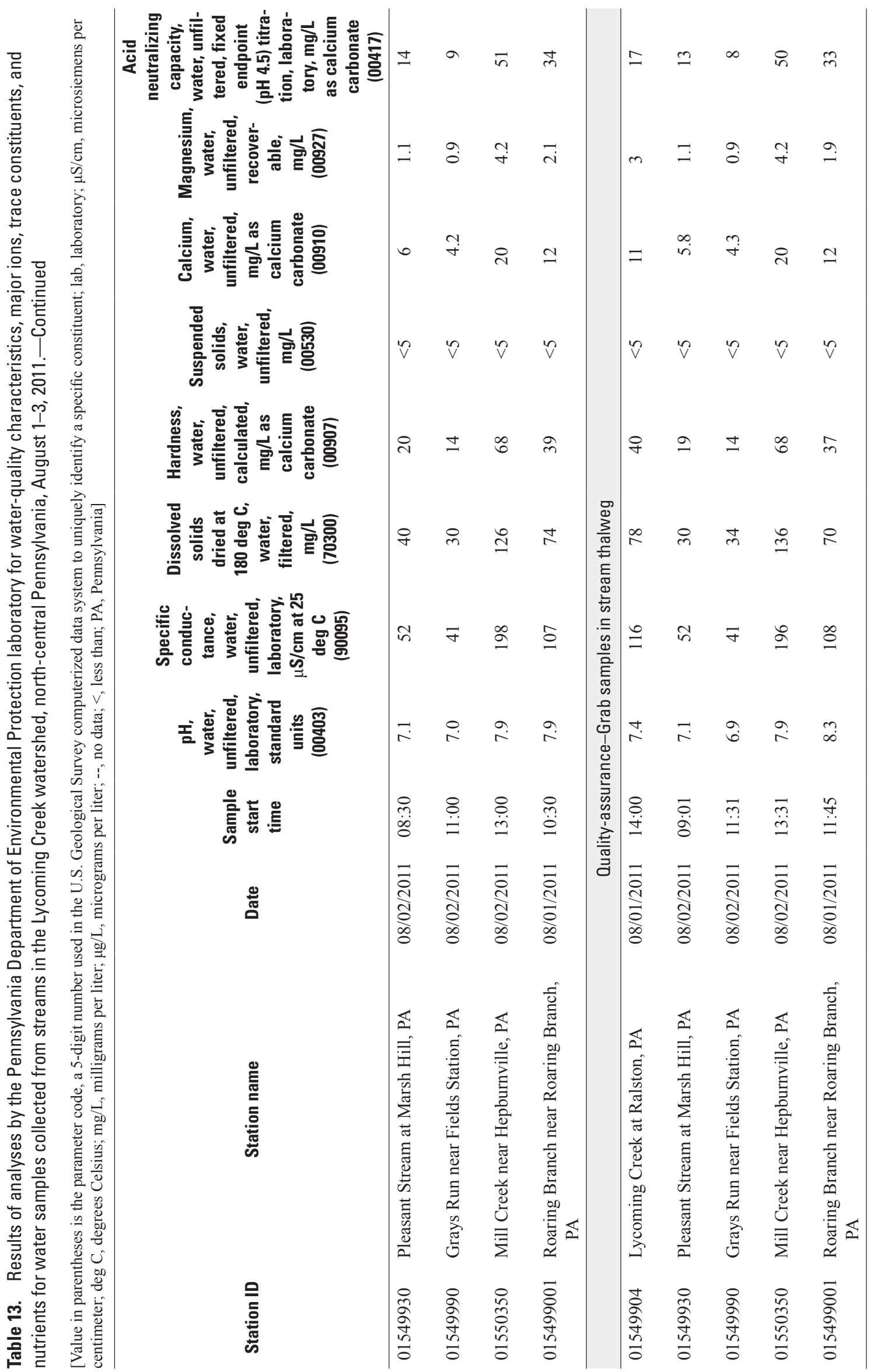




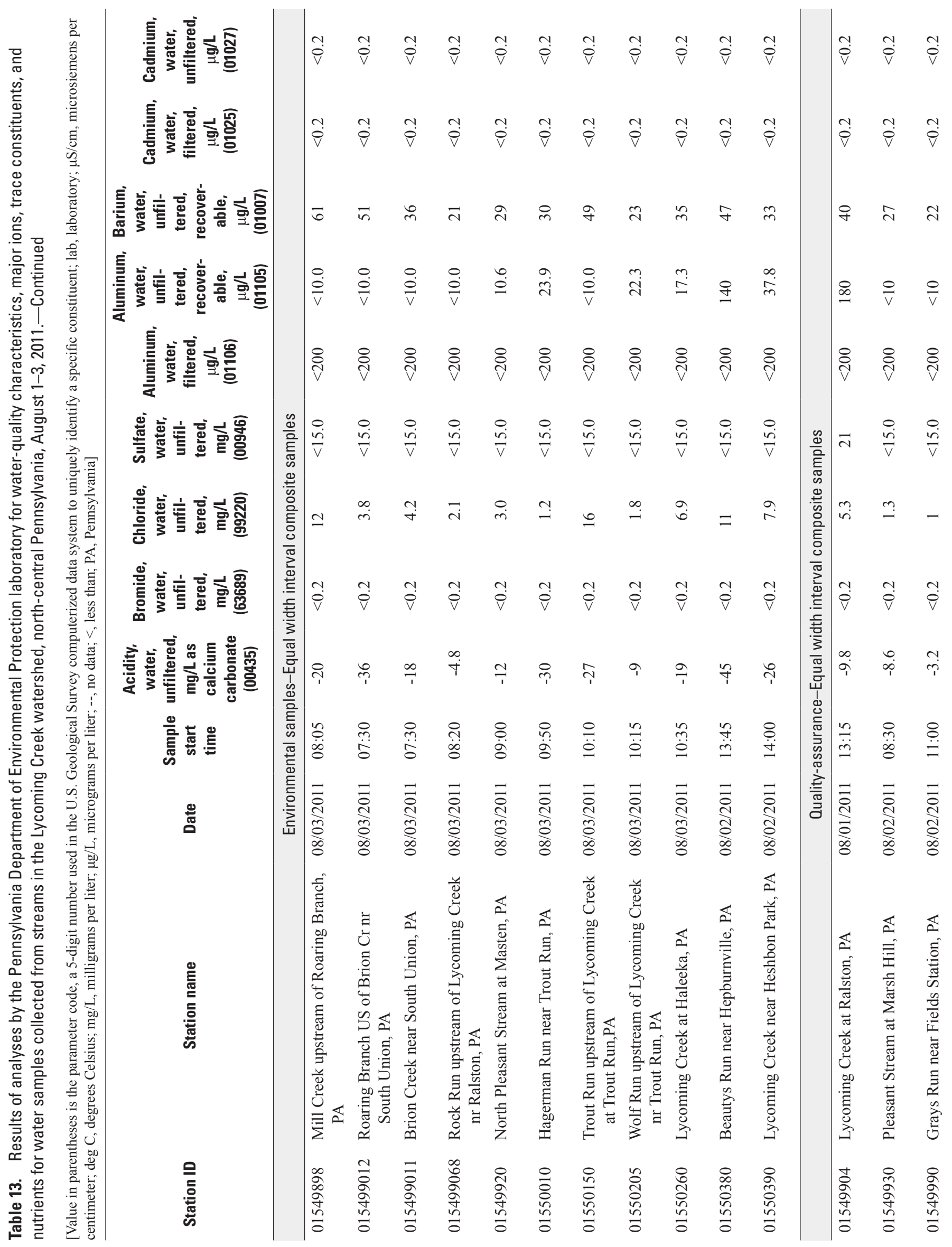




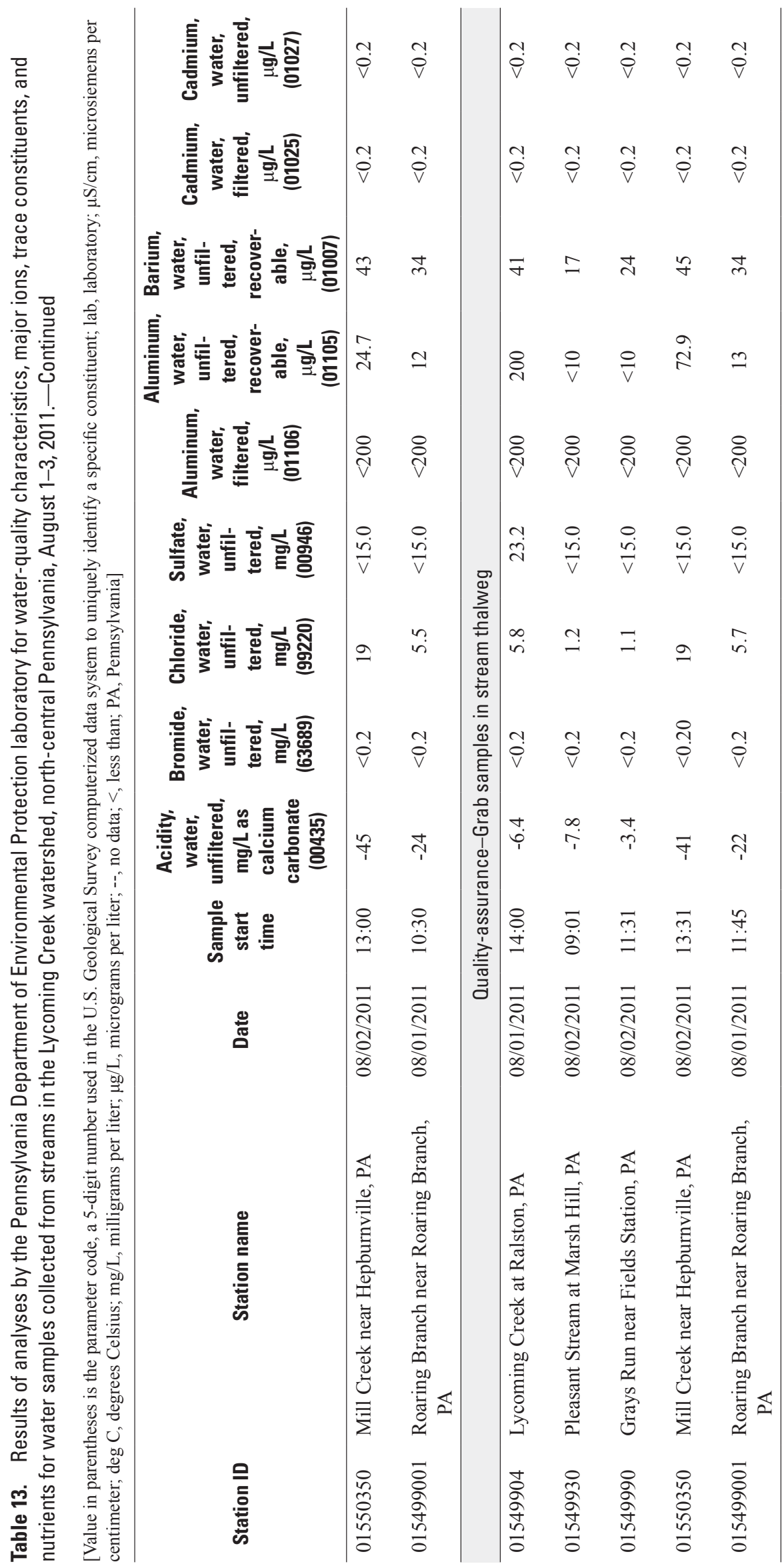




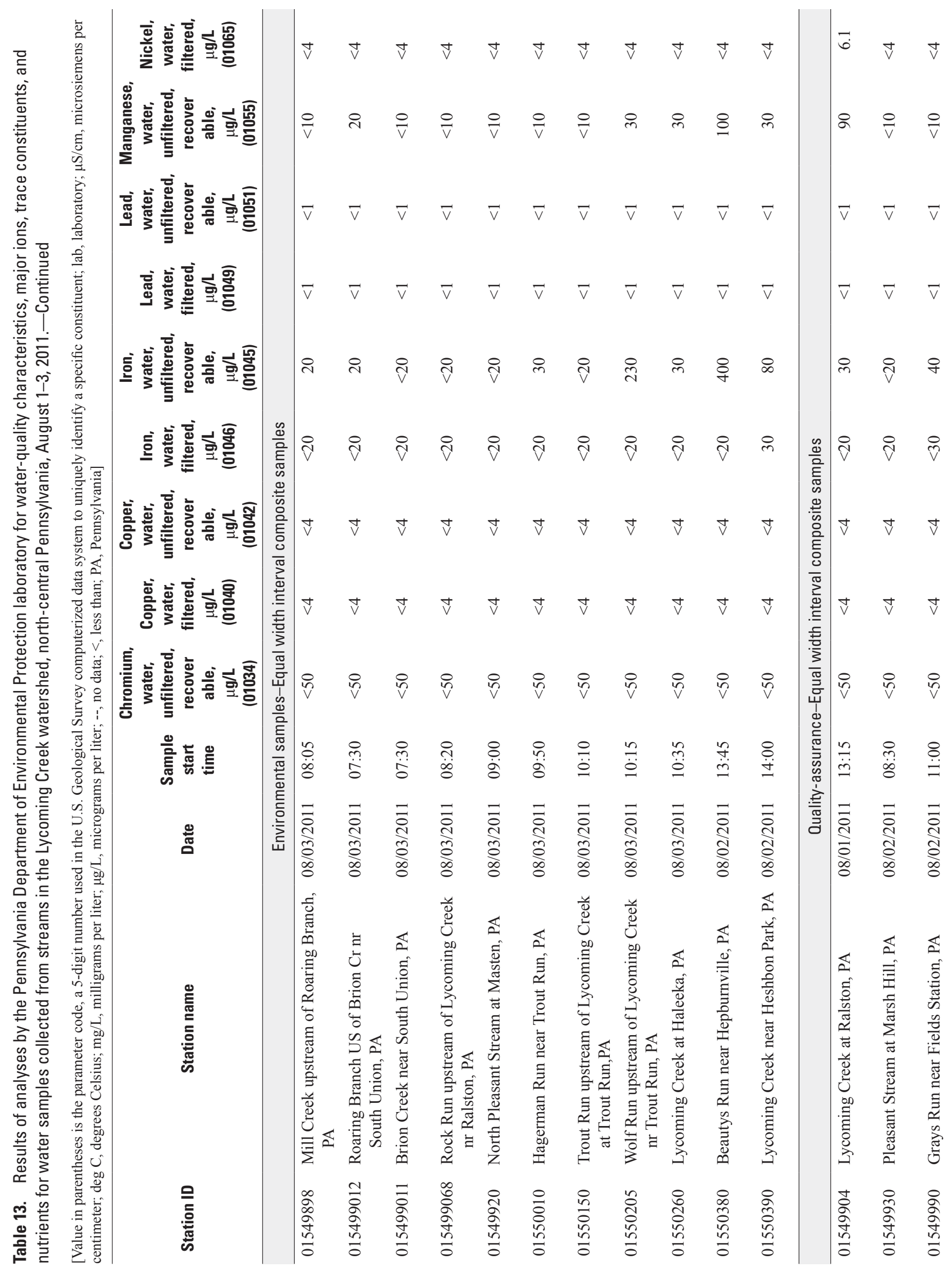




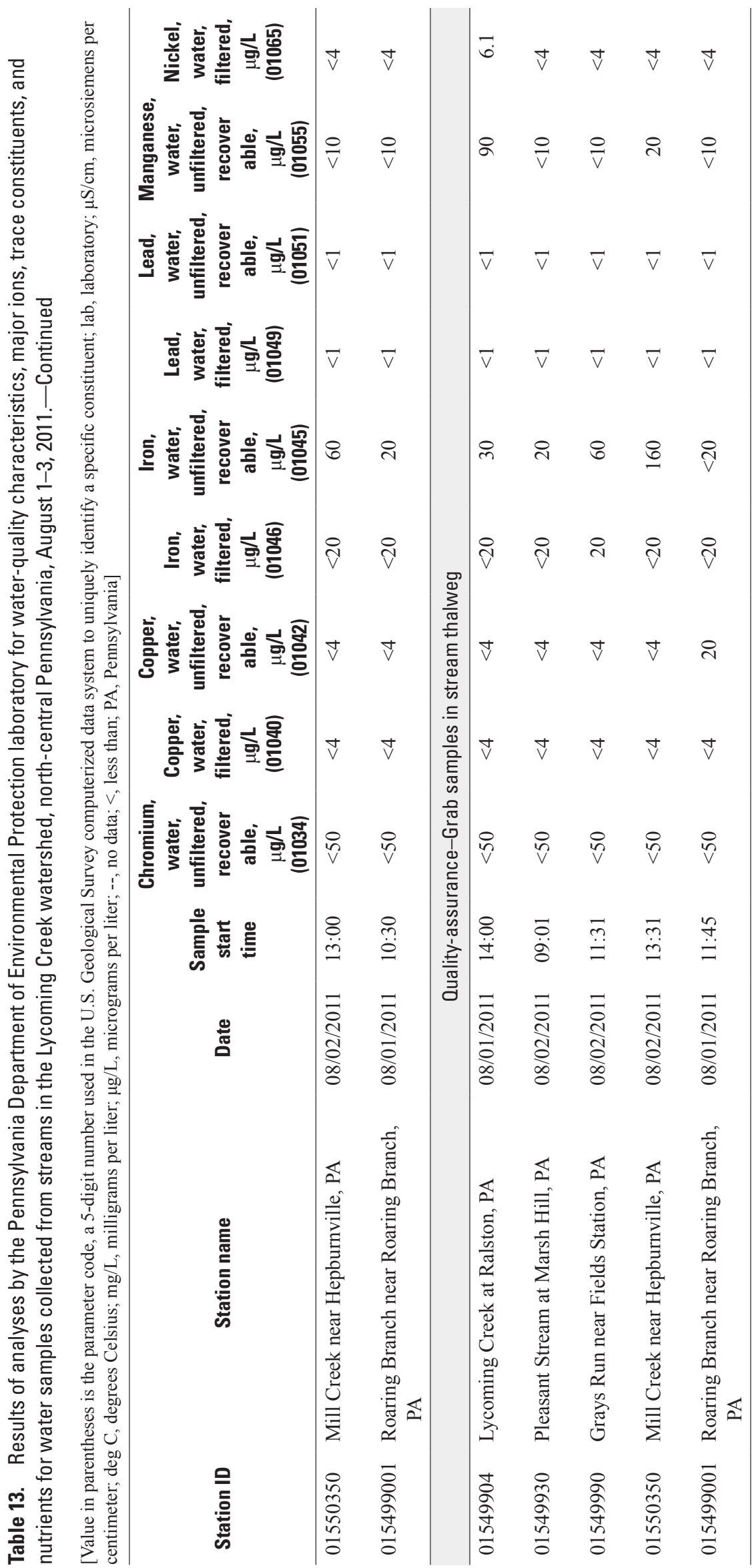




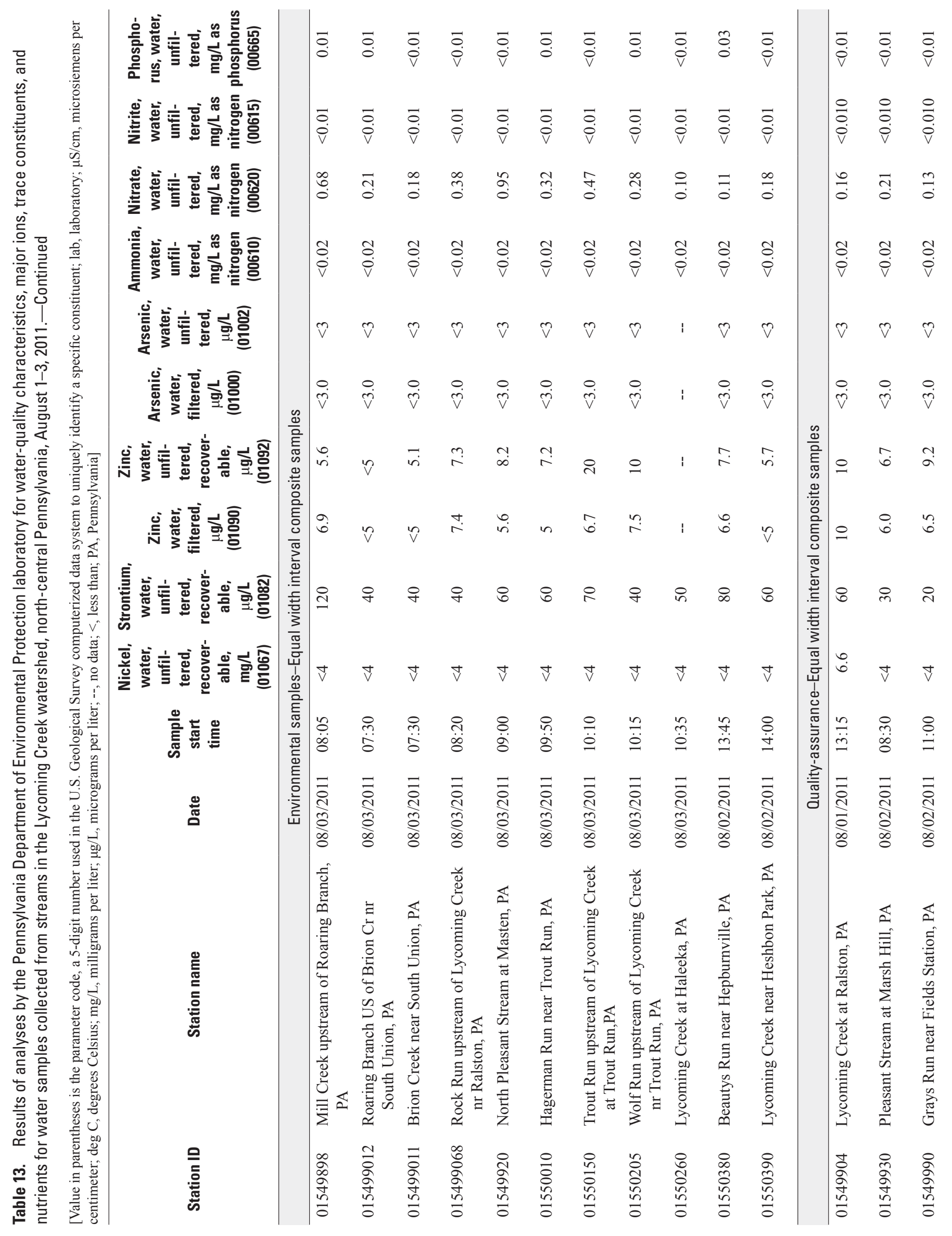




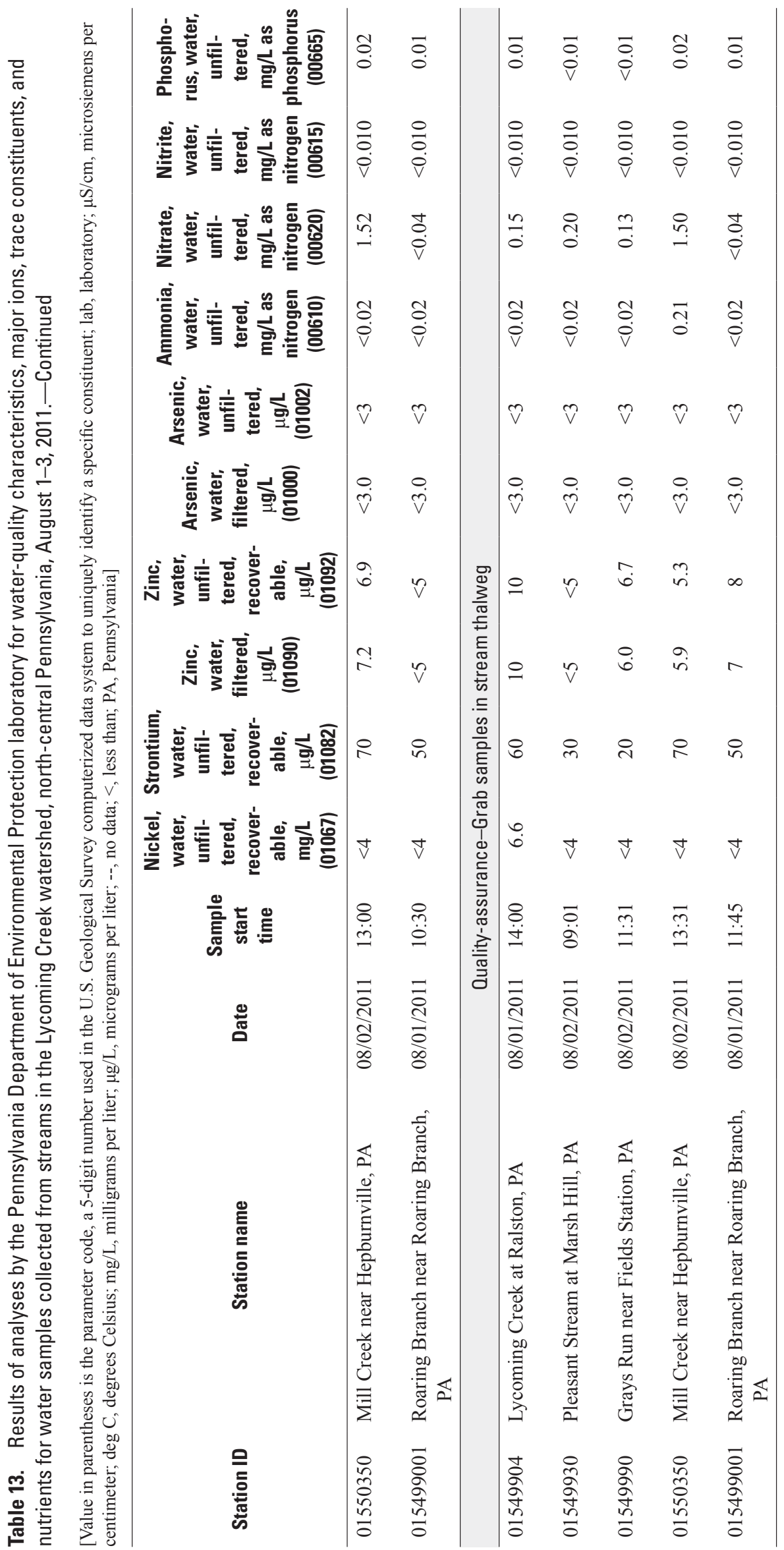


For additional information, contact:

Director, Pennsylvania Water Science Center

U.S. Geological Survey

215 Limekiln Road

New Cumberland, Pa. 17070

or visit our website at: http://pa.water.usgs.gov/

Prepared by USGS West Trenton

Publishing Service Center 
